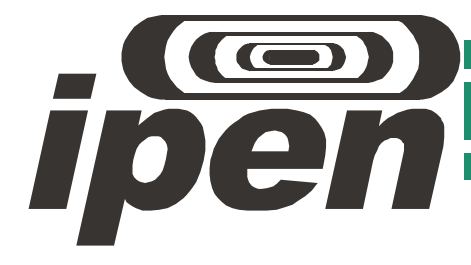

AUTARQUIA ASSOCIADA À UNIVERSIDADE DE SÃO PAULO

\title{
ESPECTROSCOPIA DE FLUORESCÊNCIA NA OTIMIZAÇÃO DA TERAPIA FOTODINÂMICA EM CARCINOMA ESPINOCELULAR DE PELE E SUA AVALIAÇÃO UTILIZANDO TOMOGRAFIA POR COERÊNCIA ÓPTICA
}

Viviane Pereira Goulart

\author{
Dissertação apresentada como parte \\ dos requisitos para obtenção do Grau \\ de Mestre em Ciências na Área \\ de Tecnologia Nuclear - Materiais \\ Orientadora: \\ Profa. Dra. Denise Maria Zezell
}


IPEN-INSTITUTO DE PESQUISAS ENERGÉTICAS E NUCLEARES Autarquia associada á Universidade de São Paulo

\title{
ESPECTROSCOPIA DE FLUORESCÊNCIA NA OTIMIZAÇÃO DA TERAPIA FOTODINÂMICA EM CARCINOMA ESPINOCELULAR DE PELE E SUA AVALIAÇÃO UTILIZANDO TOMOGRAFIA POR COERÊNCIA ÓPTICA
}

Viviane Pereira Goulart

\begin{abstract}
Dissertação apresentada como parte dos requisitos para obtenção do Grau de Mestre em Ciências na área de Tecnologia Nuclear - Aplicações.
\end{abstract}

ORIENTADORA:

Profa. Dra. Denise Maria Zezell

SÃO PAULO

2012 


\section{Dedicatória}

Ao meu filho Marcos Vinícius, por todo carinho e compreensão. nesta fase da minha Vida. 


\section{Agradecimentos Especiais}

À Deus e a Nossa Senhora da Aparecida, por tornar tudo possível.

Aos meus queridos pais Waldir e Sonia, por toda atenção, dedicação e apoio em todos os anos da minha Vida.

À minhas irmãs Angelica e Carolline, pelo apoio e momentos de felicidades e descontração.

Ao meu eterno namorado Jonathan, pelo amor, carinho, amizade e atenção incondicionais.

À minha sogra Mercia por todo carinho e atenção nos meus desabafos.

Aos meus sobrinhos Giovana, Manuella e Guilherme, pelas brincadeiras que me fazem voltar a ser criança.

À minhas amigas Carla e Sune pela linda amizade, companheirismo e confidencias desde a nossa infância. 


\section{Agradecimentos}

À minha orientadora Dra. Denise Maria Zezell, pelos ensinamentos, apoio e paciência, desde a minha iniciação científica. Pelos incentivos em momentos difíceis, amizade, carinho e dedicação.

À Dra. Luciana Correia, pela disposição em me ajudar com a histologia e clarear muitas idéias.

Ao Dr. Anderson Zanardi de Freitas, pelos ensinamentos de OCT e a disponibilização do seu laboratório.

Ao Instituto de Pesquisas Energéticas e Nucleares (IPEN) e ao Centro de Lasers e Aplicações (CLA), pela infra-estrutura concedida nestes anos de pós-graduação.

Ao meu amigo Moisés pelo apoio, companheirismo, amizade, paciência e ajuda em toda a parte experimental do meu trabalho.

À minha amiga Carol pela amizade, apoio, momentos de descontração e desabafo e boas conversas.

Aos meus amigos Paulo, Patty, Cacau, Marcelo, Thiago, Maira, Strefezza pelo convívio, momentos de trabalho e descontração.

Ao Valdir, técnico do Laboratório, pela grande convivência e amizade desde a Iniciação Científica e ao Tort pela montagem das fontes dos lasers.

Aos amigos do Centro de Lasers e Aplicações, Ana, Letícia, Débora, Gláucia, China, Ilka e Renato.

À todos os funcionários do Centro de Lasers e Aplicações em especial ao Srs. Luís e Rubens pela recepção e ao otimismo de todos os dias.

À Fapesp - processos CEPID: Centro de Pesquisa Em Óptica e Fotônica (CEPOF) 98/14270-8 e CEPOF 05/51689-2 e ao CNPq INCT Instituto Nacional de Ciência e Tecnologia Fotônica processo 573.916/2008-0. 
"Leve na sua memóría para o resto de sua vida, as coísas boas que surgíram no meío das difículdades. Elas serão uma prova de sua capacidade em vencer as provas e the darão confiança na presença divina, que nos auxília em qualquer situação, em qualquer tempo, diante de qualquer obstáculo."

$\underline{\text { Chico Xavier }}$ 


\title{
ESPECTROSCOPIA DE FLUORESCÊNCIA NA OTIMIZAÇÃO DA TERAPIA FOTODINÂMICA EM CARCINOMA ESPINOCELULAR DE PELE E SUA AVALIAÇÃO UTILIZANDO TOMOGRAFIA POR COERÊNCIA ÓPTICA
}

\author{
Viviane Pereira Goulart
}

\begin{abstract}
Resumo
A terapia fotodinâmica $(P D T)$ é uma alternativa promissora de tratamento para lesões pré-cancerosas e para câncer de pele não-melanoma, como o carcinoma espinocelular, agressivo e potencialmente metastático. Visando melhorar a eficiência da terapia fotodinâmica de carcinoma espinocelular de pele, este estudo otimizou o tempo para início da terapia, avaliou a eficácia dos fotossensibilizadores ácido aminolevulínico (ALA20\%) e o metil-ester aminolevulínico (MEALA-10\%) e verificou o coeficiente de atenuação relativo à pele normal dos grupos experimentais, por meio de Tomografia por Coerência Óptica. Para a indução do tumor foi realizada a carcinogênese química (DMBATPA) por um período de 28 semanas. A espectroscopia de fluorescência foi utilizada para monitoração da emissão da molécula de protoporfirina IX, induzida pelo ALA e MEALA. A aquisição de dados a cada 30 minutos totalizando um período de 360 minutos, permitiu verificar a máxima incorporação de ALA e MEALA em 300 e 330 minutos após a aplicação, respectivamente. Após a otimização foi realizada a $P D T$, avaliação clínica, histopatológica e análise por OCT dos grupos experimentais, por meio das quais verificou-se maior eficiência do grupo tratado com MEALA. No período de 20 dias, o percentual de lesões com redução de área maior que 50\%, foi de $33 \%$ na PDT com ALA e $83 \%$ para o MEALA. Os coeficientes de atenuação ópticos para os grupos com neoplasia foram maiores do que os do grupo controle. Os grupos tratados com PDT apresentaram valores de coeficiente de atenuação que se aproximam dos valores obtidos para a pele sadia, evidenciando a resposta ao tratamento. Entretanto para ambos os fotossensibilizadores utilizados, a PDT mostrou-se eficaz quando iniciada nos tempos determinados neste estudo, e a técnica de OCT mostrou-se uma potencial ferramenta na avaliação deste tratamento.
\end{abstract}




\title{
FLUORESCENCE SPECTROSCOPY IN THE OPTIMIZATION OF PHOTODYNAMIC THERAPY OF SKIN SQUAMOUS CELL CARCINOMA AND ITS EVALUATION BY OPTICAL COHERENCE TOMOGRAPHY
}

\author{
Viviane Pereira Goulart
}

\begin{abstract}
Photodynamic therapy $(P D T)$ is a promising alternative for pre-cancerous lesions and non-melanoma skin cancer treatment as squamous cells carcinoma, which is aggressive and potentially metastatic. Aiming the improvement of photodynamic therapy efficiency for skin squamous cells carcinoma, this study has optimized the time to start the therapy, it also evaluated the effectiveness of the aminolevulinic acid (ALA-20\%) and methyl-ester aminolevulinic (MEALA-10\%) as photosensitizers as well as verified the optical attenuation coefficient relative to normal skin of the experimental groups by optical coherence tomography (OCT). A chemical carcinogenesis was performed (DMBA/TPA), by a period of 28 days. Fluorescence Spectroscopy was used to monitor the emission of protoporphyrin IX induced by ALA and MEALA. Signal acquisition was performed every 30 minutes for a total period of 360 minutes, showing a maximum incorporation of ALA and MEALA, 300 and 330 minutes after the application. PDT was conducted after the optimization of the irradiation time. Clinical and histopathologic evaluation and OCT analysis of the experimental groups showed higher efficiency of the MEALA-treated group. After 20 days of treatment, the percentage of lesions with area reduction greater than $50 \%$, was $33 \%$ for the ALA group and $83 \%$ for the MEALA group. The optical attenuation coefficients for groups with cancer were higher than those in the control group. The groups treated with $P D T$ presented attenuation coefficient values that are close to the values obtained for healthy skin, showing the positive response to the treatment. This study showed that PDT was effective for both photosensitizers when initiated at the times determined in this study, and OCT technique proved to be a potential tool in the assessment of this treatment.
\end{abstract}




\section{SUMÁRIO}

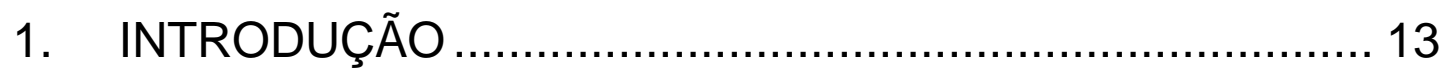

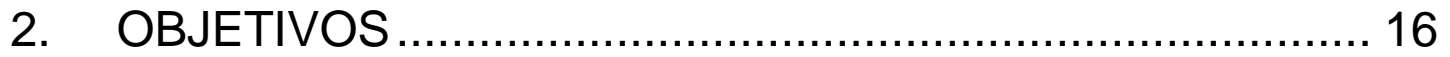

3. REVISÃO BIBLIOGRÁFICA ............................................ 17

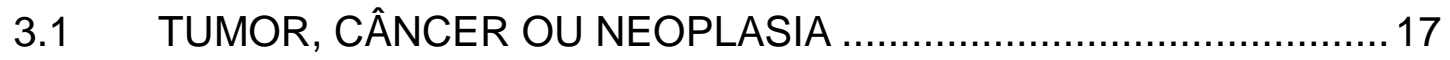

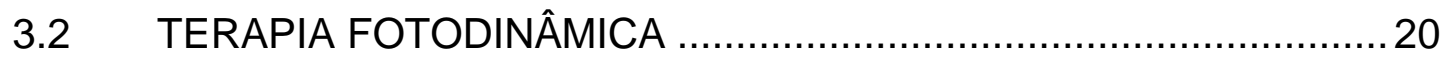

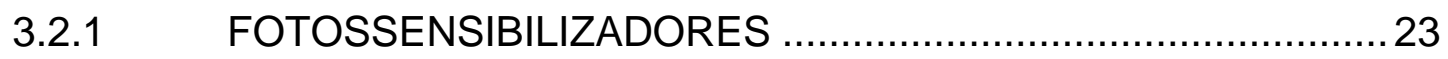

3.3 TÉCNICAS ÓPTICAS DE DIAGNÓSTICO ……………………......28

3.3.1 ESPECTROSCOPIA DE FLUORESCÊNCIA.............................28

3.3.2 TOMOGRAFIA POR COERÊNCIA ÓPTICA ……………….......35

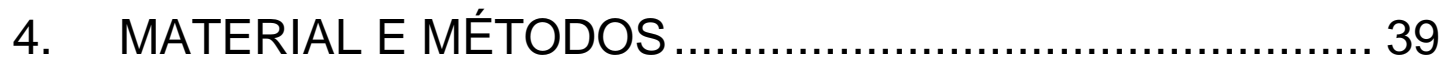

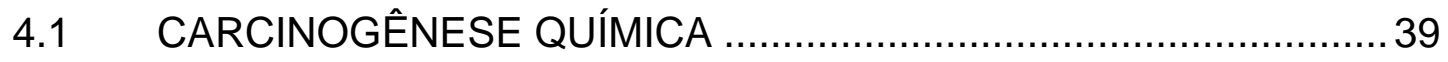

4.2 PREPARAÇÃO DA POMADA ..................................................... 41

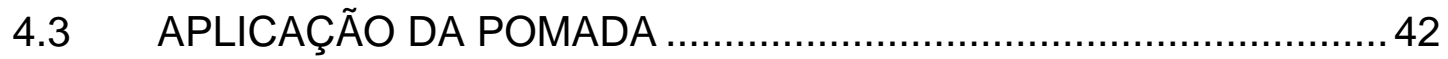

4.4 ESPECTROSCOPIA DE FLUORESCÊNCIA .................................. 43

4.5 TERAPIA FOTODINÂMICA ……………………………............ 46

4.5.1 PROCEDIMENTO DE IRRADIAÇÃO......................................... 46

4.6 TOMOGRAFIA POR COERÊNCIA ÓPTICA ……………................. 47

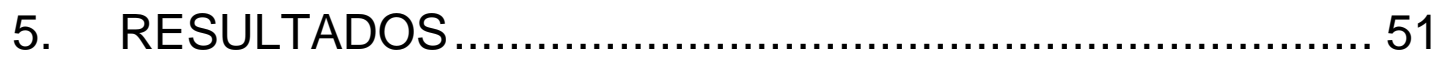

5.1 MONITORAÇÃO DA FLUORESCÊNCIA EMITIDA PELA PPIX .......51

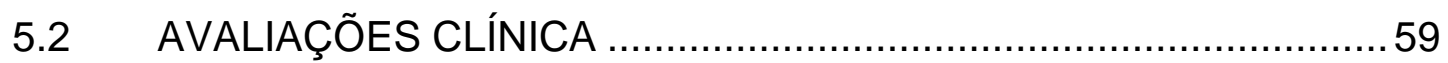

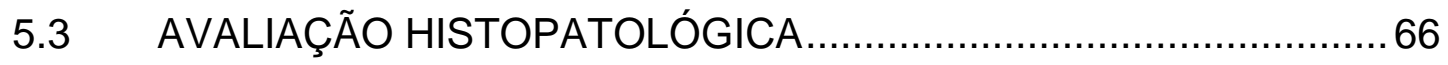

5.4 TOMOGRAFIAS POR COERÊNCIA ÓPTICA …………………......

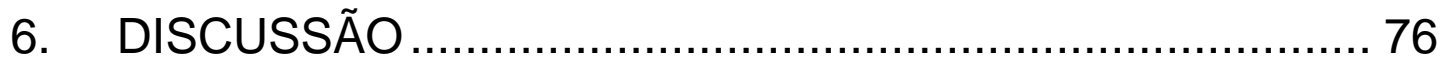

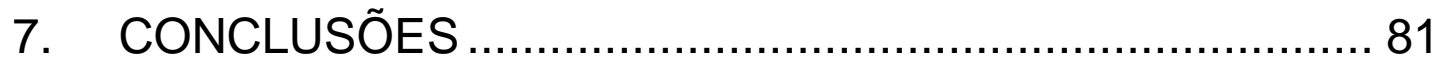

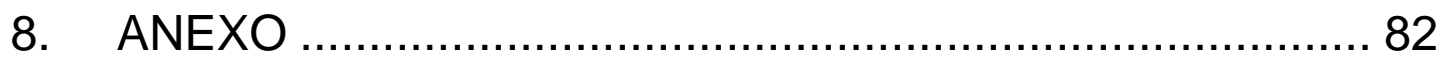

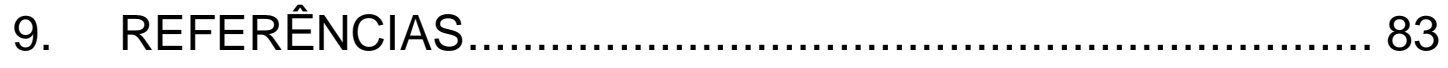




\section{LISTA DE FIGURAS}

FIGURA 1: Mecanismos de reação Tipo I e Tipo II de geração de ROS, pela combinação da luz, fotossensibilizador e oxigênio no estado fundamental. ..............22

FIGURA 2: Via Biossintética da Heme, conversão do ALA em protoporfirina IX. ......24

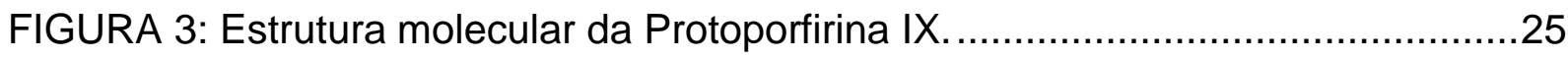

FIGURA 4: Banda de Soret e bandas Q espectro de absorção das porfirinas. .........26

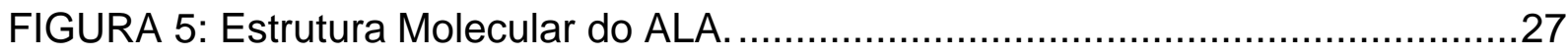

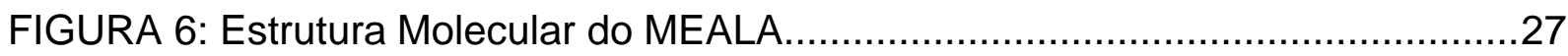

FIGURA 7: Diagrama de Jablonski. Mecanismo da Fluorescência............................29

FIGURA 8: Espectros de absorção e emissão de biomoléculas presentes na pele...30

FIGURA 9: Esquema de funcionamento do espectrômetro destacando o caminho óptico da luz de excitação, da reflexão e da fluorescência, além dos principais componentes: Laser de excitação, cabo de fibras ópticas em $\mathrm{Y}$, espectrofotômetro e computador

FIGURA 10: llustração esquemática de um arranjo OCT. .37

FIGURA 11: Imagens representativas da carcinogênese química. 40

FIGURA 12: Camundongos com carcinoma espinocelular em diferentes estágios. A esquerda, 9 semanas e a direita 28 semanas após a carcinogênese química.

FIGURA 13: Arranjo óptico da espectroscopia de fluorescência para monitoramento da fluorescência emitida pela PPIX induzida pelos FFS no tecido neoplásico. .45

FIGURA 14: Espectro representativo gerado nas leituras de fluorescência da PPIX.46

FIGURA 15: Irradiação das lesões com o Cluster de LED, $\lambda=630 \mathrm{~nm}$. 47 
FIGURA 16: Sistema de OCT utilizado para tomada de dados da pele dos grupos controle e experimentais.

FIGURA 17: Interface do Programa utilizado para análise das imagens de OCT......49

FIGURA 18: Intensidade média e erro padrão da fluorescência medida em $\lambda=635 \mathrm{~nm}$ (PPIX) do grupo controle fotossensibilizado pelo ALA (Grupo 2) em função do tempo.

FIGURA 19: Intensidade média e erro padrão da fluorescência medida em $\lambda=635 \mathrm{~nm}$ (PPIX) do grupo controle fotossensibilizado pelo MEALA (Grupo 3) em função do tempo. .52

FIGURA 20: Intensidade média da fluorescência medida em $\lambda=635 \mathrm{~nm}$ (PPIX) do grupo neoplásico fotossensibilizado pelo ALA (Grupo 4) em função do tempo. ........53

FIGURA 21: Intensidade média da fluorescência medida em $\lambda=635 \mathrm{~nm}$ (PPIX) do grupo neoplásico fotossensibilizado pelo MEALA (Grupo 5) em função do tempo. ...54

FIGURA 22: Correlação da irradiância entre os G2 (controle) e G4 (neoplásia) na incorporação do fotossensibilizador ALA. As barras representam o erro padrão. .....55

FIGURA 23: Correlação da irradiância entre os G3 (controle) e G5 (neoplasia) na incorporação do fotossensibilizador MEALA. As barras representam o erro padrão. 57

FIGURA 24: Imagens representativas da neoplasia maligna de pele induzida em camundongos: (A) antes da PDT (dia 0); (B) 10 dias após PDT; (C) 20 dias após PDT com ALA. 60

FIGURA 25: Resposta à $P D T$ em percentual de lesões com redução de área. Resposta dos ambos os tratamentos nos tempos de 0 à 10 dias e 0 à 20 dias.

FIGURA 26: Resposta à $P D T$ representada pelo percentual de redução de área de lesão nos tempos de 10 e 20 dias após o tratamento com os fotossensibilizadores ALA e MEALA. As barras representam o erro padrão.

FIGURA 27: Resposta clínica classificada em \% de redução de área das lesões dos grupos que foram submetidos ao tratamento de terapia fotodinâmica com 0 fotossensibilizadores ALA. 
FIGURA 28: Resposta clínica classificada em \% de redução de área das lesões dos grupos que foram submetidos ao tratamento de terapia fotodinâmica com 0 fotossensibilizadores MEALA. .65

FIGURA 29: Microscopia de luz de cortes histológicos representativos. (A), (C) e (E) Pele sadia do grupo controle (objetivas de 4X, 10X e 20X, respectivamente. (B), (D) e (F) Lesões neoplásicas no dia 0 (objetivas de 4X, 10X e 20X) respectivamente.......67

FIGURA 30: Microscopia de luz de cortes histológicos representativos. (A) e (B) Lesões Neoplásicas após a PDT com ALA -10 dias e 20 dias, respectivamente (objetivas de 10X). (C) e (D). Lesões Neoplásicas após a PDT com MEALA -10 dias e 20 dias, respectivamente (objetivas de 10X) ...................................................6

FIGURA 31: Imagens de OCT, (A) Pele Sadia e (B) Tecido Neoplásico. ..................70

FIGURA 32: Coeficiente de atenuação óptico relativo, dos grupos G1(controle), G4 e G5(neoplasia), G6 e G7 (neoplasia10 e 20 dias) calculado para profundidade de 0 á $400 \mu \mathrm{m}$. As barras correspondem ao erro padrão.

FIGURA 33: Coeficiente de atenuação óptico relativo, dos grupos G1(controle), G4 e G5 (neoplasia), G6 e G7 (neoplasia10 e 20 dias) calculada para profundidade de 20 á $400 \mu \mathrm{m}$. As barras correspondem ao erro padrão .72

FIGURA 34: Coeficiente de Atenuação óptico relativo, dos grupos G1(controle), G4 e G5 (neoplasia), G6 e G7 (neoplasia 10 e 20 dias) calculado para profundidade de 10

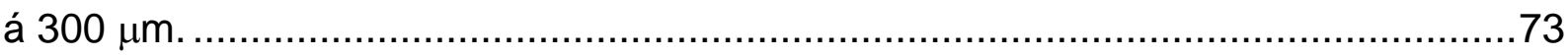




\section{Introdução}

O câncer é uma patologia caracterizada pelo descontrole nos processos básicos de proliferação, diferenciação e morte das células. Estas células possuem o material genético modificado que podem sofrer mutações desencadeadas por fenômenos externos como radiações, substâncias químicas, tabagismos etc. Apesar das características em comum, diferentes tipos de câncer têm causas muito diferentes, e possuem diferentes respostas ao tratamento ${ }^{1,2}$.

Segundo a Organização Mundial da Saúde (OMS) no ano 2030, podem-se esperar 27 milhões de casos incidentes de câncer, 17 milhões de mortes por câncer e 75 milhões de pessoas vivendo com câncer. $O$ maior efeito deste aumento vai incidir em países de baixa e média renda ${ }^{3}$.

As estimativas para o ano de 2012/2013 no Brasil apontam a ocorrência de aproximadamente 518.510 casos novos de câncer, incluindo os casos de câncer de pele não melanoma, com 134 mil casos novos, será o mais incidente na população brasileira, reforçando a magnitude do problema do câncer ${ }^{3}$.

Diante desta preocupante estatística se fazem necessárias medidas de ações preventivas e educativas, como a divulgação de efeitos prejudiciais causados pelo consumo de tabaco, álcool e pela exposição excessiva ao sol. Também são necessários investimentos na área da pesquisa, visando uma detecção precoce e um tratamento mais efetivo para esta doença não crônica que mais leva a população ao óbito.

A espectroscopia de fluorescência e a tomografia por coerência óptica $(O C T)$ são técnicas ópticas que vêm sendo apresentadas para detecção e como auxiliares para o diagnóstico de neoplasias, porque apresentam o potencial de discriminação tecidual de maneira segura, não invasiva e de resposta rápida, além de apresentar uma menor influência do avaliador, como podem ocorrer na técnica de padrão ouro histopatológica. Estas técnicas baseiam-se na interação da luz com o tecido biológico, a qual é influenciada pela composição química e da estrutura do 
tecido, de forma que as características ópticas de ambos os tecidos sadios e neoplásicos sejam claramente distintas ${ }^{4,5}$. Por isso, 0 monitoramento da fluorescência, reflectância ou absorbância podem ser correlacionados com as alterações celulares e teciduais malignas do tecido.

A terapia fotodinâmica (Photodynamic Therapy - PDT) é um método de tratamento que utiliza a interação entre um agente fotossensibilizador, luz e oxigênio molecular $^{6,7,8,9,10}$ e foi utilizada inicialmente para o tratamento de neoplasia ${ }^{41}$. A PDT envolve a aplicação sistêmica, intraperitoneal, tópica ou intralesional de uma substância química fotossensível não tóxica denominada fotossensibilizador e uma subsequente irradiação com luz de comprimento de onda específico no local acometido pela lesão ${ }^{11,12,13,14,15}$.

As principais pró-drogas em uso de forma tópica são ácido 5aminolevulínico (ALA) e do seu metil éster (MEALA). Ambos são precursores de um fotossensibilizante endógeno, a protoporfirina IX (PPIX), que é expresso em todas as células nucleadas de mamíferos, mas em níveis baixos, inferiores aos que poderiam causar fotossensibilidade. Após a aplicação de ALA ou MEALA no tumor da pele ou lesão o pró-fármaco é absorvido nas células anormais e convertido através do ciclo da heme PPIX'16.

O fotossensibilizador de porfirina, PPIX, possui banda de máxima absorção na região azul-violeta do espectro eletromagnético (Banda de Soret), mas esta faixa de comprimento de onda é de baixa penetração no tecido, menor que 1 $\mathrm{mm}$. Em vista disso, a excitação geralmente utilizada na $P D T$ é na região do vermelho (banda entre 630-635 nm), mesmo que este comprimento de onda possua menor intensidade no espectro de absorção da PPIX, sua penetração é maior, atingido até $6 \mathrm{~mm}^{16}$.

Apesar da $P D T$ já ter obtido um grande avanço desde sua origem, ainda há limitações a serem superadas que são: a distribuição da luz utilizada para excitar a molécula do fotossensibilizador no tecido, as variadas estruturas e composições teciduais que alteram a forma com que a luz se propaga; a oxigenação do tecido a 
ser tratado e o consumo de oxigênio que alteram o mecanismo de dano celular; e a variação da concentração do fotossensibilizador no tecido ${ }^{17}$.

Entre o grande número de parâmetros, o tipo de fotossensibilizador, a dose de luz, o intervalo de tempo entre a aplicação do fotossensibilizador e a irradiação luminosa são obviamente cruciais para a otimização da PDT. Sendo assim nosso trabalho visou otimizar o melhor tempo para realizar esta terapia em carcinoma espinocelular, realizar a terapia com o uso da formulação farmacêutica patenteada pelo grupo e assim caracterizar opticamente o tecido nas várias fases do experimento. 


\section{Objetivos}

- Estimar e otimizar o inicio da terapia fotodinâmica, utilizando a espectroscopia de fluorescência;

- Comparar a eficiência do ácido aminolevulínico (ALA-20\%) e o metil-ester aminolevulínico (MEALA-10\%) utilizando-se a terapia fotodinâmica no tratamento de carcinoma espinocelular induzido em pele.

- Determinar o coeficiente de atenuação óptico da pele a partir da tomografia por coerência óptica $(O C T)$ dos grupos antes e após a terapia fotodinâmica com os fotossensibilizadores ALA e MEALA no período de 10 e 20 dias. 


\section{Revisão Bibliográfica}

\subsection{Tumor, Câncer ou Neoplasia}

Tumor, sinônimo de neoplasma ou blastoma, é o crescimento anormal de tecidos. Células com um distúrbio genético passam a se reproduzir mais rapidamente do que as células normais levando à formação do tumor, podendo este ser caracterizado como benigno ou maligno. Quando o crescimento do tumor é muito acelerado, desorganizado e com tendência a se alastrar a outros órgãos, geralmente é maligno ${ }^{18,19,20}$.

Câncer ou neoplasia é a designação genérica e científica de qualquer tumor maligno; a palavra câncer é derivada do latim e significa caranguejo. O nome é decorrente da facilidade com que este crustáceo tem de se aderir firmemente em qualquer lugar, assim como a neoplasia se adere a um local do corpo humano em que se desenvolve ${ }^{21}$.

Segundo dados do Instituto Nacional do Câncer (INCA) no Brasil no ano de 2012/2013 os tipos mais incidentes de câncer serão os cânceres de pele não melanoma, próstata, pulmão, cólon e reto e estômago para o sexo masculino; e os cânceres de pele não melanoma, mama, colo do útero, cólon e reto e glândula tireóide para o sexo feminino ${ }^{3}$.

O câncer de pele é o mais frequente no Brasil e corresponde a $25 \%$ de todos os tumores malignos registrados no país. Apresenta altos percentuais de cura, se for detectado precocemente. Existem dois grupos distintos de câncer da pele: 0 não melanoma, mais frequente e menos agressivo, e os melanomas, mais agressivos, porém mais raro ${ }^{3}$.

Os fatores de risco para esses tipos de câncer envolvem características individuais tais como tipo de pele, pouca melanina para a proteção da pele à exposição solar, propensão a queimadura, histórico familiar e nível de exposição 
solar ao longo da vida ${ }^{18,22 .}$ Os radicais livres são produzidos em várias vias intracelulares e são aumentados durante a inflamação, infecção e exposição a poluentes e luz do sol. O estresse oxidativo gerado a partir de radicais livres, por sua vez oxida e danifica várias proteínas e DNA, levando a instabilidade genômica e câncer ${ }^{23}$.

O câncer de pele melanoma é o menos frequente dentre os tumores da pele, porém sua letalidade é mais elevada. Acomete principalmente os caucasianos que moram em países com alta intensidade de radiação ultravioleta. Se detectados em estágios iniciais, os melanomas são curáveis e seu prognóstico é considerado bom $^{24}$.

O câncer da pele não melanoma (NMSC) é uma doença que acomete mais as populações de pele clara. Hispânicos, asiáticos e negros desenvolvem menos esse tipo de câncer. São tumores de crescimento lento, localmente invasivos e raramente resultam em metástase à distância. Uma pequena proporção torna-se letal e o número de óbitos resultante desse câncer é muito baixo. É, portanto, uma neoplasia de bom prognóstico, com altas taxas de cura se tratado de forma adequada e oportuna. Contudo, em alguns casos em que há demora no diagnóstico, esse câncer pode levar a ulcerações e deformidades físicas graves ${ }^{24,25}$.

Em 2012, estima-se, para o Brasil, 62.680 casos novos de câncer da pele não melanoma entre homens e 71.490 em mulheres. O câncer de pele não melanoma pode apresentar tumores de diferentes linhagens. Os mais frequentes são carcinoma basocelular eles são responsável por 70\% dos diagnósticos é o menos agressivo e raramente apresenta metástase, e o carcinoma espinocelular ou epidermóide, representando $25 \%$ dos casos, sendo mais agressivo e pode apresentar metastase ${ }^{3}$.

O carcinoma basocelular ( $\mathrm{CBC}$ ) tem origem nas células basais da epiderme, é caracterizado por queratinócitos basais invadindo a derme. Sua ocorrência é maior em pessoas de meia idade e idosos de pele clara. Seu surgimento esta relacionado com a exposição à radiação solar, é localmente invasivo de crescimento lento ${ }^{26}$. 
O carcinoma espinocelular (CEC) é originado dos queratinócitos da epiderme tem um padrão de crescimento destrutivo e metastático, é reconhecido por suas crostas hiperqueratinócitas, ou ulcerações em estágios posteriores ${ }^{27}$. É frequentemente resultado de uma queratose actínica, ou seja, lesões pré-cancerosas sem tratamento. São localizadas em locais exposto ao sol como: dorso da mão antebraço, rosto e couro cabeludo ${ }^{26,28}$.

A prevenção e o diagnóstico são fundamentais para lidar como câncer de pele. A prevenção depende, principalmente, do uso de protetor solar ou vestimentas para o caso do trabalhador. Já o diagnóstico precoce pode evitar o agravamento da doença, a complexidade e custo do tratamento e a morte do paciente ${ }^{22,29}$.

O diagnóstico precoce é fundamental para alcançar um tratamento e resultado favorável a esta doença que acomete grande parte da população, no entanto o diagnóstico do câncer de pele pode ser difícil. Na prática clínica, o exame visual determina se uma lesão de pele é cancerosa com base na regra $A B C D E$ (assimetria, borda, cor, diâmetro, e evolução) e na alteração da aparência de uma verruga ou área pigmentada ao longo de um período de tempo. No entanto, a sensibilidade e especificidade do diagnóstico clínico podem variar muito, dependendo dos conhecimentos e habilidades visuais do médico. Os médicos passam por um desafio inicial de decidir quais e quantas lesões devem ser realizadas biopsias. Este processo é subjetivo e meticuloso, podendo ser particularmente fácil negligenciar a doença. A remoção desta lesão para um exame histopatológico parece ser a solução mais simples, porem é um procedimento invasivo que deixa cicatriz e em caso de lesões benignas pode resultar custos desnecessários e desconforto ao paciente ${ }^{3,26,30}$.

Atualmente 0 diagnóstico confiável ainda requer biópsia e exame histopatológico, processo que pode levar até duas semanas para sair o resultado. Este protocolo para diagnóstico de lesão de pele é o padrão ouro, porém como foi dito é invasivo, subjetivo, demorado e caro ${ }^{26,31}$. Esta limitação motivou o desenvolvimento de técnicas ópticas como: espectroscopia de fluorescência (FS), microscopia de fluorescência excitada por dois fótons (TPEF), tomografia por 
coerência óptica $(O C T)$ entre outras técnicas não invasivas capazes de caracterizar estas lesões de pele cancerosas de forma direta. Tais ferramentas têm o potencial para auxiliar na orientação das biopsias e, no futuro, contornar a necessidade de biopsia e exame histopatológico completamente ${ }^{32}$.

As formas tradicionais de tratamento para lesões pré-cancerosas dermatológicas incluindo queratose actínica (AQ), doença de Bowen (BD) e o câncer de pele não melanoma envolvem a excisão cirúrgica, curetagem, crioterapia, quimioterapia e radioterapia.

Uma alternativa e promissora forma de tratamento viável para uma variedade grande de neoplasias surgiu na década de 70 , é a terapia fotodinâmica $(P D T)^{33}$ que resulta na destruição seletiva de tecidos neoplásicos, através da produção de oxigênio singleto e outras espécies reativas de oxigênio (ROS), que induzem numerosas vias celulares resultando em morte celular via apoptose, necrose,e autofagia. Para o sucesso da PDT são necessários três componentes críticos: um fotossensibilizador, a irradiação com uma luz de comprimento de onda apropriado e oxigênio molecular suficiente ${ }^{34,35}$.

O uso da PDT em Medicina ainda está sob investigação6, ${ }^{7,36,37}$, entretanto, já esta sendo considerada sua aplicação clínica6 ${ }^{38}$. Com o desenvolvimento de novos fotossensibilizadores e tipos de luz, com custos viáveis, a terapia fotodinâmica certamente se tornará uma importante técnica de tratamento para neoplasias malignas.

\subsection{Terapia Fotodinâmica}

Durante os últimos anos, a PDT tem sido clinicamente estudada e aplicada como uma modalidade de tratamento local de uma variedade de alterações cutâneas, como a queratose actínica que é considerada uma lesão pré-neoplásica, a doença de Bowen, o carcinoma espinocelular (CEC) e o carcinoma de células basais

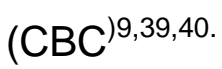


A terapia fotodinâmica $(P D T)$ combina a administração tópica ou sistêmica de um fotossensibilizador e a iluminação seletiva da lesão alvo com uma luz compatível com o espectro de absorção do fotossensibilizador, resultando em dano fotooxidativo localizado e subsequente morte celular ${ }^{8,11,12,16,41,83}$.

O objetivo da PDT é a destruição seletiva das células-alvo anormais, através de sua fotossensibilização, tanto pela administração de moléculas fotossensibilizadoras exógenas (porfirinas, clorinas, ftalocianinas, entre outras) quanto pelo uso de vias biossintéticas endógenas. A busca por novos fármacos fotossensíveis potencialmente ativos na PDT e com propriedades espectroscópicas melhores como absorção na região espectral das fontes de iluminação (laser ou não), maior penetração nos tecidos biológicos, melhores propriedades de biodistribuição in vivo, resultam em várias opções de fotossensibilizadores (FFS) ${ }^{33,42}$.

Dentre os fotossensibilizadores os que merecem destaque são os derivados de porfirinas: ácido aminolevulínico (ALA) e o metil éster aminolevulínico (MEALA), são precursores de protoporfirina IX (PPIX) substância fotossensível. A aplicação tópica desses agentes representa a técnica mais usual de PDT na Dermatologia ${ }^{42}$.

A ativação da substância fotossensível pela absorção da luz transfere a molécula de um estado energético fundamental para um estado excitado. No estado excitado a molécula pode decair diretamente de volta ao estado inicial e emitir fluorescência, que pode ser fotodetectada, ou ainda, atingir um estado tripleto e, na presença de oxigênio, a molécula excitada irá reagir diretamente com os substratos celulares por meio de transferência de prótons e elétrons para formar radicais que irão interagir com este oxigênio, produzindo produtos oxigenados (reação tipo I). Alternativamente, a energia da molécula fotossensível excitada também pode ser diretamente transferida para as formas de oxigênio singleto (reação tipo II), que é a forma de maior dano celular promovida pela PDT. Esta formação de espécies altamente reativas de oxigênio dentro da membrana celular, citoplasma ou organelas, libera reações perioxidativas causando danos no DNA e em outras 
moléculas, culminando na morte celular ${ }^{12,83,43,44}$. A FIGURA 1 ilustra os mecanismos de reações de tipo I e II.

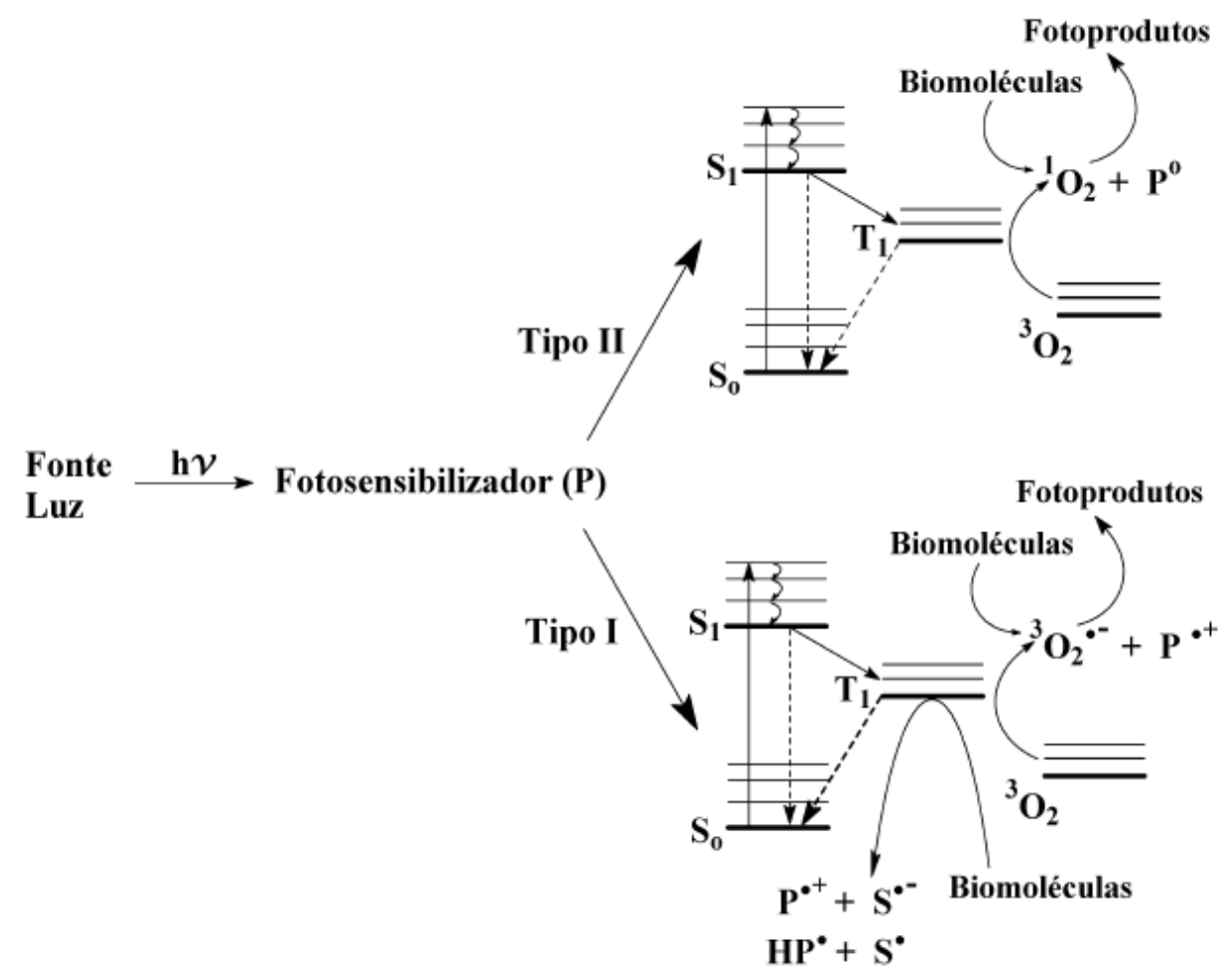

FIGURA 1: Mecanismos de reação Tipo I e Tipo II de geração de ROS, pela combinação da luz, fotossensibilizador e oxigênio no estado fundamental ${ }^{42}$.

A morte das células pelo agente citotóxico (oxigênio singleto ou ROS) pode se dar pela indução de apoptose e necrose, reações inflamatórias, reações imunes além da ocorrência de danos à vasculatura dos vasos do tumor e da vizinhança saudável, resultando na morte indireta do tumor via indução da hipóxia ou inanição. Para alguns fotossensibilizadores o mecanismo de efeito terapêutico é mais importante que o vascular ${ }^{45}$.

Há uma variedade de fontes de luz que têm sido utilizados em PDT. Geralmente, são luzes vermelhas, laser ou fonte não coerente, estudos demonstram não haver nenhuma diferença significativa na eficácia entre os dois ${ }^{16,46}$. 
Historicamente, fontes xênon foram utilizadas, mas o tempo mudou e uma gama de fluorescente, fontes de iodetos metálicos e de filamento de tungstênio foi empregado antes do desenvolvimento de matrizes de LED mais baratas. Os LED são agora as fontes mais utilizadas na $P D T$ tópica no uso de ambulatório portáti ${ }^{16}$.

Para garantir a efetividade da técnica de PDT fatores como: o fotossensibilizador utilizado, sua penetração no tecido tumoral e tempo de clearance no tecido, duração da aplicação, da fonte de irradiação, da habilidade da luz em penetrar no tecido alvo e da duração da exposição a essa luz, do tipo de células-alvo e da presença de oxigênio no tecido são de grande importância ${ }^{47,48}$.

\subsubsection{Fotossensibilizadores}

A qualidade dos fotossensibilizadores é importante para a eficácia do tratamento fotodinâmico. A pureza química, a capacidade de se localizar especificamente em tecidos neoplásicos, o curto intervalo de tempo entre a administração do fármaco e a sua acumulação máxima no tumor, semi-vida curta e rápida depuração do tecido normal, absorção de comprimentos de onda ideal para a penetração no tecido, elevados rendimentos quânticos para a geração de oxigênio singleto e ausência de toxicidade são características desejáveis de um fotossensibilizador ideal ${ }^{49,50}$.

Além de um fotossensibilizador eficaz outro pré-requisito fundamental para uma ótima resposta terapêutica da $P D T$ é uma quantidade suficiente de droga localizada no tecido tumoral. Inicialmente, os fotossensibilizantes são absorvidos pelas células normais e malignas, mas são retidos mais tempo em certos tecidos, especialmente em tumores com proliferação rápida. Os mecanismos desta prolongada retenção seletiva não são entendidos em detalhe ${ }^{51}$.

A evidência experimental para a acumulação desta molécula nas células neoplásicas foi que a atividade de ferroquelatase é reduzida, enquanto que a atividade da porfobilinogênio-desaminase é melhorada. A interrupção do estrato 
córneo, o aumento da permeabilidade e do número dos vasos sanguíneos, assim como a fraca drenagem linfática em tecidos neoplásicos, pode contribuir para a retenção do fármaco nas lesões neoplásicas. $\mathrm{O}$ valor de $\mathrm{pH}$ mais baixo do fluido intersticial em tumores facilita a biodistribuição seletiva dos fotossensibilizantes, aumentando o seu caráter lipofílico e sua captação em células malignas ${ }^{50,51}$.

Por razões históricas e devido à facilidade de administração do medicamento à pele, as principais atividades da dermatologia oncológica vêm utilizando aplicações do ALA em $P D T^{51}$.

$\mathrm{O}$ ácido 5-aminolevulínico (ALA) é aplicado topicamente à pele e convertido através da via biossintética do grupo heme, representada na FIGURA 2, para o fotossensibilizador endógeno protoporfirina IX, sendo assim o ALA não é em si mesmo um fotossensibilizador, mas todas as células eucarióticas metabolizam-no e induzem a produção de PPIX molécula fotossensível endógena ativa ${ }^{16,83}$.

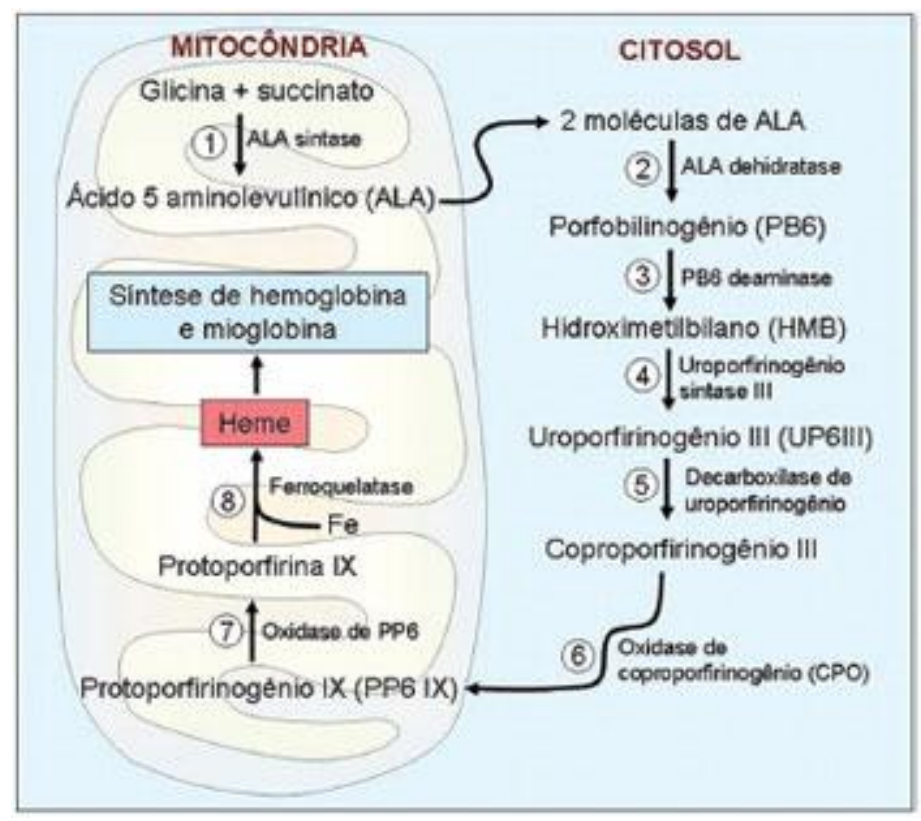

FIGURA 2: Via Biossintética da Heme, conversão do ALA em protoporfirina IX.

A síntese da PPIX é normalmente regulada por um mecanismo de feedback negativo. O ALA é formado na mitocôndria, pela condensação da glicina e 
succinato, pela ação da enzima ALA-síntase, em seguida a atividade da enzima porfobilinogênio-desaminase, que catalisa a formação do uroporfirinogênio a partir do porfobilinogênio, é maior em alguns tumores, enquanto a ferroquelatase, que converte a PPIX é menor, resultando em um maior acúmulo da PPIX nas células neoplásicas ${ }^{52,83}$.

A formação estimulada exogenamente da molécula de PPIX (FIGURA 3) está se tornando uma das áreas de maior desenvolvimento no campo da terapia fotodinâmica $(P D T)$ e fluorescência de fotodetecção (PD) de doenças malignas e não-malignas ${ }^{35,51}$.

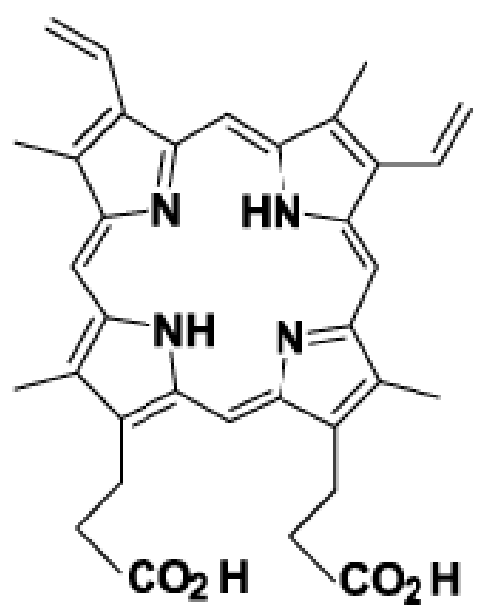

FIGURA 3: Estrutura molecular da Protoporfirina IX.

Após a exposição à luz, podendo esta ser um laser ou LED, a PPIX induz efeitos citotóxicos através de reações fotoquímicas dependentes de oxigênio que danificam principalmente a mitocôndria, onde é sintetizada, e nas membranas plasmática induzindo nas células malignas a morte celular ${ }^{53,54}$.

A PPIX pode ser ativada por comprimentos de onda que vão desde UV até $410 \mathrm{~nm}$ conhecida por banda de Soret (FIGURA 4) com um pico máximo em 375$405 \mathrm{~nm}$. A Banda de Soret é seguida por outras bandas de absorção mais fracas (bandas Q), em comprimentos de ondas maiores (450 a $700 \mathrm{~nm}$ ). Apesar do pico máximo de absorção desta molécula ser na faixa do azul este comprimento de onda 
é bastante espalhado atingindo predominantemente a superfície, sendo assim o comprimento de onda mais utilizado na $P D T$ é na faixa do vermelho para que haja uma melhor e mais profunda penetração no tecido tumoral ${ }^{48,55}$.

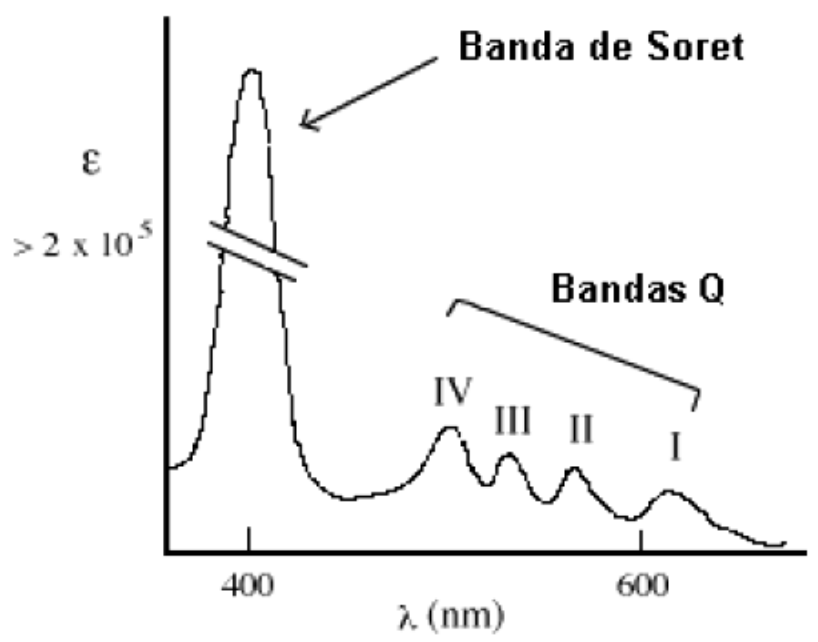

FIGURA 4: Banda de Soret e bandas Q espectro de absorção das porfirinas.

Apesar dos resultados promissores, o ALA (FIGURA 5) é uma molécula hidrofílica, sua penetração através das membranas celulares e para o espaço intersticial dos tecidos é baixa. Assim, a formação da PPIX induzida é muitas vezes limitada à camada superficial do tecido, por causa da falta de homogeneidade e sua distribuição parcial nas lesões profundas e nodulares. Portanto lesões profundas muitas vezes não são acessíveis para $P D T$, ou exigem mais aplicações tópicas de ALA. Consequentemente, doses relativamente elevadas de ALA deve ser aplicada por períodos longos de tempo, aumentando o risco de complicações ${ }^{51,56}$. 


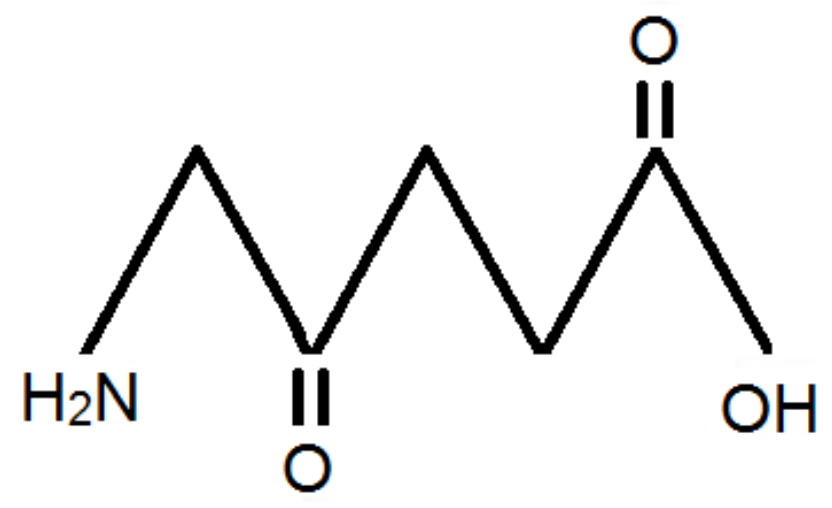

FIGURA 5: Estrutura Molecular do ALA.

Devido a estas desvantagens, nos últimos anos iniciou-se a busca por derivados mais lipofílicos de ALA, a fim de melhorar a fraca biodisponibilidade do mesmo. Vários grupos mostraram que a utilização de pró-fármacos como o MEALA (FIGURA 6) pode aumentar a concentração de PPIX por até duas ordens de grandeza em comparação com a molécula original ${ }^{51,56}$.

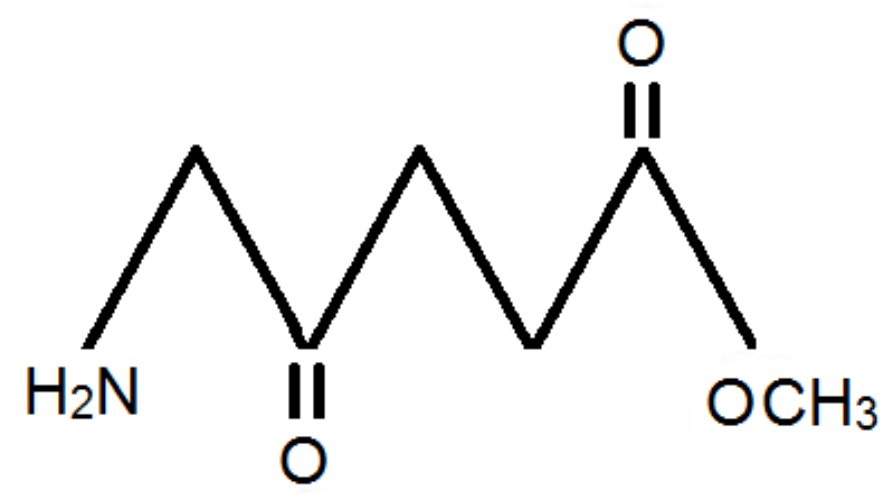

FIGURA 6: Estrutura Molecular do MEALA.

Estudos in vitro e in situ comprovam que o MEALA apresenta uma maior penetração no tecido tumoral e seletividade por células neoplásicas, consequentemente é mais eficaz e causa menos efeitos colaterais em tecidos normais, quando comparado com o ALA. A redução da concentração do MEALA 
também demonstra ser mais efetivo na produção de PPIX, o que pode reduzir o custo do tratamento ${ }^{83}$.

Sendo assim a PDT com estes e outros fotossensibilizadores foi provada, em laboratórios de todo o mundo e em estudos clínicos, como uma ferramenta promissora de tratamento para uma variedade de tumores de pele, incluindo carcinoma espinocelular ${ }^{41}$.

\subsection{Técnicas Ópticas de Diagnóstico}

\subsubsection{Espectroscopia de Fluorescência}

A fluorescência é um fenômeno óptico que ocorre em uma molécula cromófora depois da mesma absorver fótons do ambiente. Os fótons absorvidos pela estrutura eletrônica elevam a energia dos elétrons desta molécula a estados quânticos excitados e menos estáveis. Para a molécula excitada atingir a estabilidade necessária ela deve dissipar a energia absorvida por processos de decaimentos radiativos e/ ou não radiativos.

Os processos de decaimento não radiativos envolvem vibrações, rotações e translações da biomolécula ou transferência de energia às moléculas vizinhas por choques (cruzamentos intersistemas). A energia dissipada nesses processos está distribuída no espectro eletromagnético desde radiações no infravermelho próximo até o infravermelho distante ${ }^{57}, 58$.

Os processos radiativos envolvem a emissão de fótons. Quando a fotoemissão depende de estados quânticos singleto e tripleto ela é chamada fosforescência, quando só depende dos estados singletos da molécula ela é chamada fluorescência. Em geral a fluorescência ocorre com maior probabilidade que a fosforescência, por isso é mais comum de ser observada. Algumas características distinguem os dois fenômenos, como o tempo de vida, por exemplo. A 
emissão da fluorescência evanesce na ordem de nanosegundos enquanto que a da fosforescência pode durar até alguns segundos ${ }^{57}$. O tempo de vida $(\tau)$ de um fluoróforo é o tempo médio entre a sua excitação e retorno ao estado fundamental. Devido ao curto espaço de tempo da fluorescência, a medição da emissão necessita de um arranjo complexo de óptica e eletrônica ${ }^{58}$.

Os dados espectrais de fluorescência são geralmente apresentados com espectro de emissão, onde é representado por intensidade de fluorescência versus comprimento de onda. Uma característica importante da fluorescência é sua elevada sensibilidade.

O processo que ocorre entre a absorção e a emissão da luz é representado pelo Diagrama de Jablonski (FIGURA 7). A luz com um determinado comprimento de onda, da região espectral entre 400 a $700 \mathrm{~nm}$, é absorvida pelo tecido, e emitida em um comprimento de onda maior de menor energia.

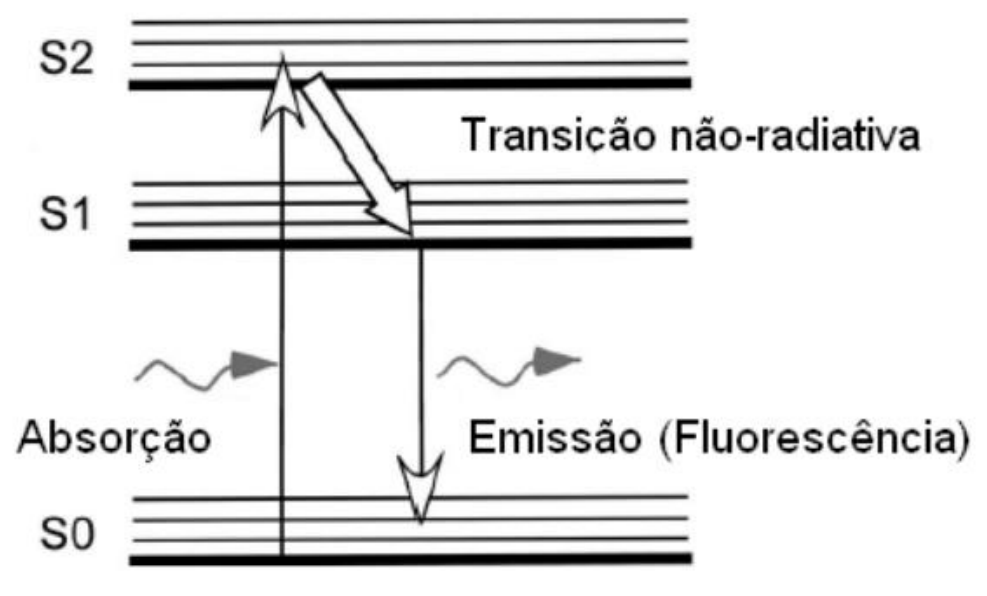

FIGURA 7: Diagrama de Jablonski. Mecanismo da Fluorescência ${ }^{5}$.

A fluorescência emitida depende da característica eletrônica da molécula que a emitiu, logo pode ser empregada como uma ferramenta de identificação de moléculas, dependendo da luz utilizada para realizar a excitação, alguns compostos tem a fluorescência bem característica.

Para utilizar a fluorescência, como método de identificação de moléculas de interesse no tecido biológico, é necessário conhecer as regiões de absorção e 
emissão destas amostras, a (FIGURA 8) representa os respectivos espectros de algumas biomoléculas, da região de $200 \mathrm{~nm}$ e $500 \mathrm{~nm}$.
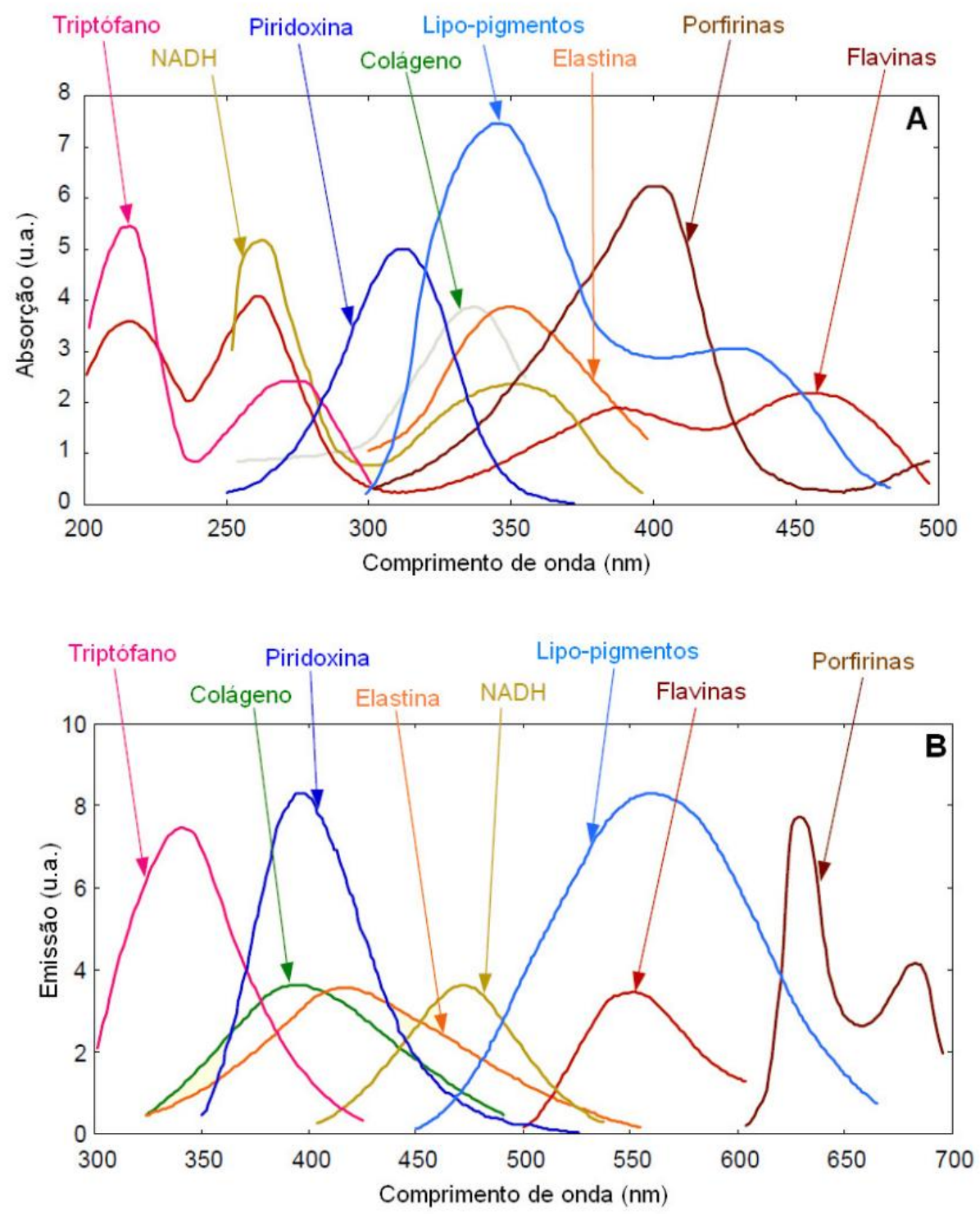

FIGURA 8: Espectros de absorção e emissão de biomoléculas presentes na pele ${ }^{58}$.

A magnitude da fluorescência detectada é inerente a concentração de fluoróforo, no entanto, também é dependente das propriedades ópticas do tecido, ou seja, a absorção e espalhamento reduzido. Esta dependência da propriedade óptica ocorre tanto na excitação quanto na emissão de comprimentos de onda. Em geral, as 
propriedades ópticas do tecido e o comprimento de onda de excitação vão influenciar na profundidade e distribuição da fonte no interior do tecido. Isto vai determinar a distribuição da fluorescência gerada dentro do volume dos tecidos. Uma vez que a emissão de fluorescência foi gerada, as propriedades ópticas do tecido descrevem a probabilidade de os fótons saírem do tecido e serem detectadas pelo sistema de detecção de fluorescência ${ }^{59}$.

No entanto, a capacidade de quantificar com precisão a medida de fluorescência in vivo é fundamental. O sinal de fluorescência de origem não só a partir do fotossensibilizador, mas também a partir de várias outras moléculas fluorescentes presentes naturalmente no tecido, podem causar uma quantidade desconhecida e variável de autofluorescência de fundo ${ }^{60}$. Além disso, a medida do sinal de fluorescência é também influenciada por fatores geométricos (a distância e o ângulo de excitação e detecção da fonte em relação à superfície do tecido) e a óptica de tecidos (dispersão e absorção da excitação e da emissão de fluorescência no tecido). Por exemplo, os tecidos com maiores coeficientes de absorção devido à elevada quantidade de melanina ou ao conteúdo do sangue, pode diminuir a propagação de ambos excitação e emissão da fluorescência. Isto é ainda mais complicado pelo fato de que o espectro de absorção de sangue depende da sua oxigenação. Além disso, o espalhamento do tecido tumoral é menor do que o tecido normal e a espessura interna dos tecidos são diferentes. Em geral, o tumor apresenta uma camada interna mais espessa do que o tecido normal ${ }^{61},{ }^{62}$.

A espectroscopia de fluorescência é um método óptico que está sendo usualmente empregado na identificação de elementos químicos e biomoléculas aplicado a área médica de diagnóstico de lesões teciduais. Recentemente, métodos espectroscópicos não invasivos têm sido estudados para o diagnóstico de tecidos, vários sistemas de órgãos, incluindo a pele, do trato gastrointestinal, colo do útero, e mama. A absorção de luz pode fornecer informação da composição bioquímica da pele. A propriedade de dispersão de luz da pele pode fornecer informações sobre sua microarquitetura. Espectroscopia de fluorescência pode detectar estados de doença. Porque a fluorescência é uma manifestação do ambiente bioquímico da 
célula, isto deve ser um indicador específico de alterações celulares causadas pela doença ${ }^{26}, 63$.

Esta técnica se baseia no principio de que a luz interage de maneira diferente dependendo da composição do tecido investigado, ou seja, na análise de um sinal óptico em regiões espectrais definidas, coletando o sinal de fluorescência emitido pela amostra com uma ou mais fibras ópticas as quais conduzem tal sinal para ser tratado e detectado. Portanto é o diâmetro da fibra que determina a resolução da área de interesse estudada na amostra.

Um desafio inerente para as técnicas de fluorescência é a profundidade de penetração superficial da excitação da luz. A excitação por um único fóton (ultravioleta) atinge uma profundidade inferior a $0,5 \mathrm{~mm}$ no tecido. No entanto, esta técnica é muito sensível às alterações moleculares patológicas precoces que ocorrem normalmente no tecido ou superfície do órgão. Geralmente, imagens convencionais ou técnicas espectroscópicas com maior penetração não podem perceber transformações patológicas recentes. Além disso, a maior parte das técnicas convencionais de imagem (por exemplo, a tomografia de coerência óptica) fornece informação estrutural, em vez de bioquímica e funcional ${ }^{64}$.

Em geral a espectroscopia de refletância é estudada em uma larga banda espectral, desde o visível até o infravermelho próximo (400 nm a $2500 \mathrm{~nm})$. O espectrômetro é o equipamento utilizado na espectroscopia de refletância, sendo composto por fonte emissora, fibras ópticas, elementos difrativos, componentes ópticos e uma matriz linear de fotodetectores. Em geral uma lâmpada halógena de tungstênio é usada para emissão em toda a banda estudada, mas também há instrumentos que utilizam outras fontes, entre as quais diodos emissores de luz. As fibras ópticas conduzem a radiação desde a fonte à amostra e da amostra ao espectrofotômetro.

O espectrofotômetro é composto por elementos difrativos, como prismas ou grades de difração, e pela matriz linear de fotodetectores. Uma vez que, tanto os elementos difrativos como os fotodetectores são produzidos para operar na região do 
visível ou na do infravermelho próximo, é necessário um caminho óptico para cada tipo de radiação $0^{65}, 66$.

Tradicionalmente a espectroscopia da fluorescência é realizada com laser como fonte de luz, pois é monocromático (induz a fluorescência seletivamente) e pode ser acoplado na fibra com maior eficiência que as demais fontes de luz; atualmente os diodos emissores de alto brilho surgem como uma alternativa para miniaturização dos sistemas mantendo alta intensidade para excitação das moléculas ${ }^{67}$.

O feixe laser é entregue na amostra através da fibra central do cabo em $\mathrm{Y}$, e o sinal da fluorescência e da reflexão são coletados por seis fibras periféricas, antes da entrada ao espectrofotômetro um filtro de passa alta é inserido para que a intensidade do laser seja minimizada. No espectrofotômetro a luz coletada é colimada por um espelho esférico e é difratada por uma grade de difração. Sendo assim a imagem da difração incide sobre um sensor linear tipo CCD, a qual permite a leitura do espectro em conjunto com um software fornecido pelo fabricante no nosso caso o Spectrasuite. A FIGURA 9 abaixo ilustra um sistema para fluorescência induzida por laser. 


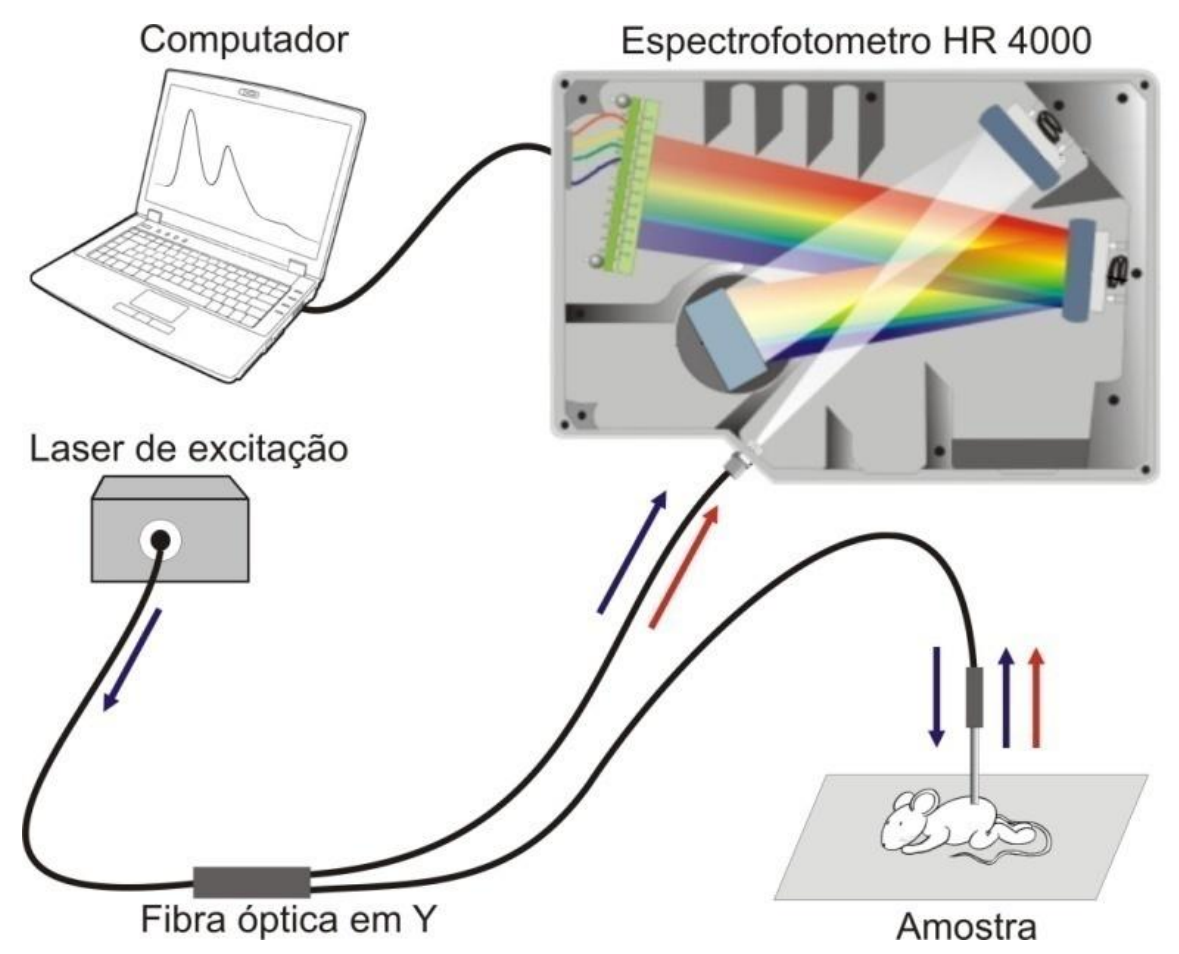

FIGURA 9: Esquema de funcionamento do espectrômetro destacando o caminho óptico da luz de excitação, da reflexão e da fluorescência, além dos principais componentes: Laser de excitação, cabo de fibras ópticas em $\mathrm{Y}$, espectrofotômetro e computador.

Para ser alcançado o melhor desempenho de um arranjo óptico que combina reflectância e espectroscopia de fluorescência e que permite a medição de todos os parâmetros com uma única fibra.

Os principais requisitos do sistema de medição podem ser resumidos da seguinte forma:

(1) medições precisas de PPIX e fotoprodutos de tecido;

(2) iluminação o mais baixo possível para evitar efeitos de PDT causado por medição;

(3) medições precisas de conteúdo no sangue e na oxigenação de tecidos;

(4) ideal, uma sonda de não contato para evitar a pressão sobre o tecido que pode alterar as propriedades do tecido; 
(5) medição e análises rápidas dos dados para fornecer informação em tempo real sobre as propriedades do tecido,

(6) para reduzir erros de operação humana, o sistema deve ser simples de ser operado por uma enfermeira ou pesquisador ${ }^{68}$.

Sendo assim a espectroscopia de fluorescência é uma técnica óptica que pode ser utilizada clinicamente para a detecção e diagnóstico de tumores e para auxiliar no monitoramento da PDT. Quando utilizada para estes fins a PPIX é excitada com luz de comprimento de onda de aproximadamente $400 \mathrm{~nm}$, assim causa a emissão de fluorescência com um pico dominante em $635 \mathrm{~nm}^{69}$.

De acordo com Argell-Petersen, et $a^{7^{0}}$, a intensidade e a seletividade da fluorescência da PPIX depende do fotossensibilizador e do tempo de aplicação antes da $P D T$, e a espectroscopia de fluorescência é ideal para alcançar a otimização da $P D T$ tópica.

\subsubsection{Tomografia por Coerência Óptica}

A técnica de tomografia de coerência óptica $(O C T)$ tem se desenvolvido rapidamente desde que foi realizada pela primeira vez em $1991^{72}$. Há vários anos o OCT tem sido disponível comercialmente e aceito como um padrão dentro de clínica de oftalmologia para o diagnóstico de doenças da retina. Desde a comercialização dos primeiros sistemas de OCT pela Carl Zeiss Meditec, em 1996, o mercado tem crescido rapidamente. Presentemente, existem mais de 20 fabricantes de sistemas e fornecedores de componentes e equipamentos. Aplicações emergentes nos domínios da biologia e medicina e vários domínios técnicos são continuamente explorados por muitos grupos de pesquisa em todo o mundo. Em paralelo, intensos esforços que visam fornecer melhorias técnica sem imagens, velocidade, resolução, qualidade de imagem, e capacidades funcionais estão em andamento ${ }^{71,72,73,74}$.

A técnica de OCT tem o potencial de visualizar estruturas da pele com resolução de alta profundidade. Uma profundidade de penetração aproximada de 
$1 \mathrm{~mm}$ é suficiente para fornecer alta resolução de imagem transversal da derme e epiderme. Enquanto isso, várias aplicações de OCT têm sido introduzido na medicina. Além de especialidades médicas como oftalmologia e medicina interna, o OCT está cada vez mais sendo usado em pesquisa em dermatologia e cosmetologia $^{75}$. Em estudos anteriores, anexos da pele e folículos de cabelo foram identificados por imagens de OCT e confirmados com observação de alterações histológicas e morfológicas tais como vesículas de tecido tumoral, processos fotoadaptativos, tais como espessamento da pele e condições inflamatórias, incluindo a psoríase e dermatite de contato ${ }^{74,76}$.

A tomografia por coerência óptica baseia-se no sinal de interferometria, no qual é utilizada uma fonte de luz com grande largura espectral e comprimento de onda próximo ao infravermelho, devido ao fato desta região do espectro sofrer menor absorção pelos principais componentes dos tecidos biológicos e, portanto ter alta penetração de fótons. Esta técnica reconstrói o perfil de retro-espalhamento óptico em profundidade de 1 a $3 \mathrm{~mm}$ para a maioria dos tecidos biológicos, pois devido ao coeficiente de espalhamento, coeficiente de absorção e suas dependências com 0 comprimento de onda, a quantidade de luz retroespalhada deste tecido pode ser insuficiente para detectar estruturas em profundidades maiores que as descritas $^{80,74,77,78}$.

São utilizados como fonte de luz, vários tipos de laser, em particular o laser de Titânio-Safira, assim como LED Superluminescentes ${ }^{79}$. A luz emitida atravessa um elemento óptico que divide o feixe em dois caminhos ópticos, sendo um direcionado para o espelho do braço de referência do interferômetro do OCT e o outro para a amostra. A luz refletida do espelho presente no braço de referência e a luz retroespalhada da amostra são recombinadas no divisor de feixe, ocorrendo interferência entre elas. A intensidade do feixe recombinante é mensurada por um detector óptico, permitindo obter informações oriundas de diferentes profundidades do tecido em estudo (FIGURA10) ${ }^{80,81}$. Os sinais de intensidade captados pelo detector são transmitidos a um computador, onde são analisados. 


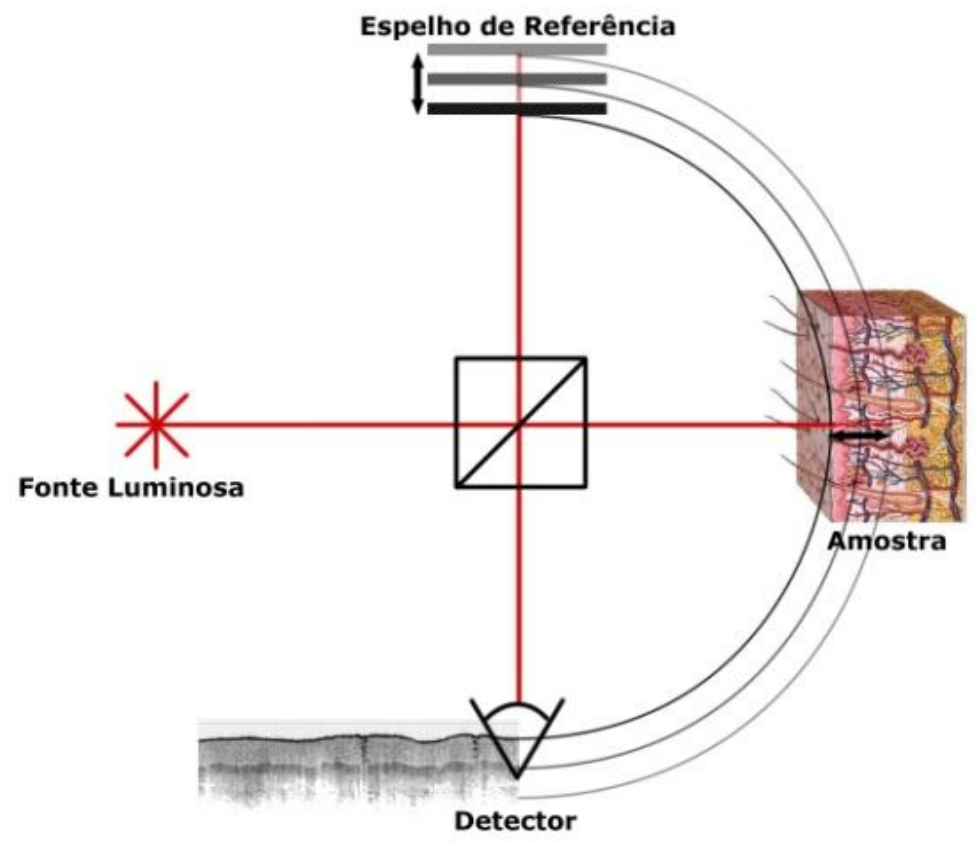

FIGURA 10: Ilustração esquemática de um arranjo $O C T^{81}$.

A especificidade da OCT pode ser também melhorada utilizando em combinação com a espectroscopia de fluorescência de tecidos, que é baseado na diferença de parâmetros espectrais de regiões patológicas e saudáveis do tecido. Para aumentar a intensidade de emissão de tumor, fluoróforos exógenos são utilizados ou sensibilizadores endógenos, como por exemplo, o ALA. A aplicação tópica ou venosa de ALA induz uma acumulação seletiva de porfirinas endógenas em células cancerosas, resultando num drástico aumento da intensidade de fluorescência de tumores comparada com a de um tecido normal, onde as porfirinas são acumuladas. A intensidade de fluorescência caracteriza a quantidade de porfirinas acumuladas nas células cancerosas e, portanto, a malignidade do processo $^{78,79}$.

Contudo, nota-se que as porfirinas não sejam acumuladas apenas nos tecidos malignos, mas também em tumores benignos, bem como em tecidos em 
proliferação que de certa forma prejudica a capacidade de diagnóstico deste método. Ao mesmo tempo, OCT visualiza variações estruturais nos tecidos, enquanto a espectroscopia de fluorescência permite estimar a quantidade de protoporfirina acumulada nos tecidos, a profundidades de até 1-2 mm. Portanto, uma combinação destes métodos representa um diagnóstico de doenças cancerosas ${ }^{78}$. 


\section{Material e Métodos}

Este trabalho teve aprovação do Comitê de Ética em Pesquisa Animal do IPEN, parecer nำ1/10- CEUA-IPEN/SP (ANEXO).

$O$ delineamento experimental deste trabalho consta com a carcinogênese química para a indução do tumor nos camundongos, para que então fosse possível a otimização e monitoração da fluorescência induzida pelo fotossensibilizadores ALA e MEALA. A partir destes resultados foi definido o melhor tempo para iniciarmos a terapia fotodinâmica nos grupos com tratamento. Após os procedimentos em todos os grupos realizamos a análise por OCT, seguida pela eutanásia dos animais e posterior coleta de tecido para avaliação histopatológica.

\subsection{Carcinogênese Química}

Para a indução do tumor foram utilizados 50 camundongos fêmeas da raça Swiss, com idades de 8 a 10 semanas, massa de $20 \mathrm{~g}$, provenientes do Biotério do IPEN-CNEN/SP. Os animais foram mantidos em condições apropriadas com acesso livre a água e ração padrão, temperatura ambiente constante, com ciclos de 12 horas de luz e escuridão.

Os animais foram anestesiados com quetamina $(0,35 \mathrm{ml} / \mathrm{Kg})$ e xilasina $(0,20 \mathrm{ml} / \mathrm{Kg})$, dose anestésica utilizada em todos procedimentos e etapas do estudo. Seu dorso foi submetido a assepsia e a tricotomia, em seguida, iniciou-se a carcinogênese química composta por duas fases ${ }^{82}$.

A primeira fase consistiu na iniciação,com aplicação tópica de dose única de $50 \mu \mathrm{g}$ de DMBA (7,12-dimetil-benzantraceno) diluídos em $100 \mathrm{ml}$ de acetona para a pipetagem, como ilustra a FIGURA 11. 

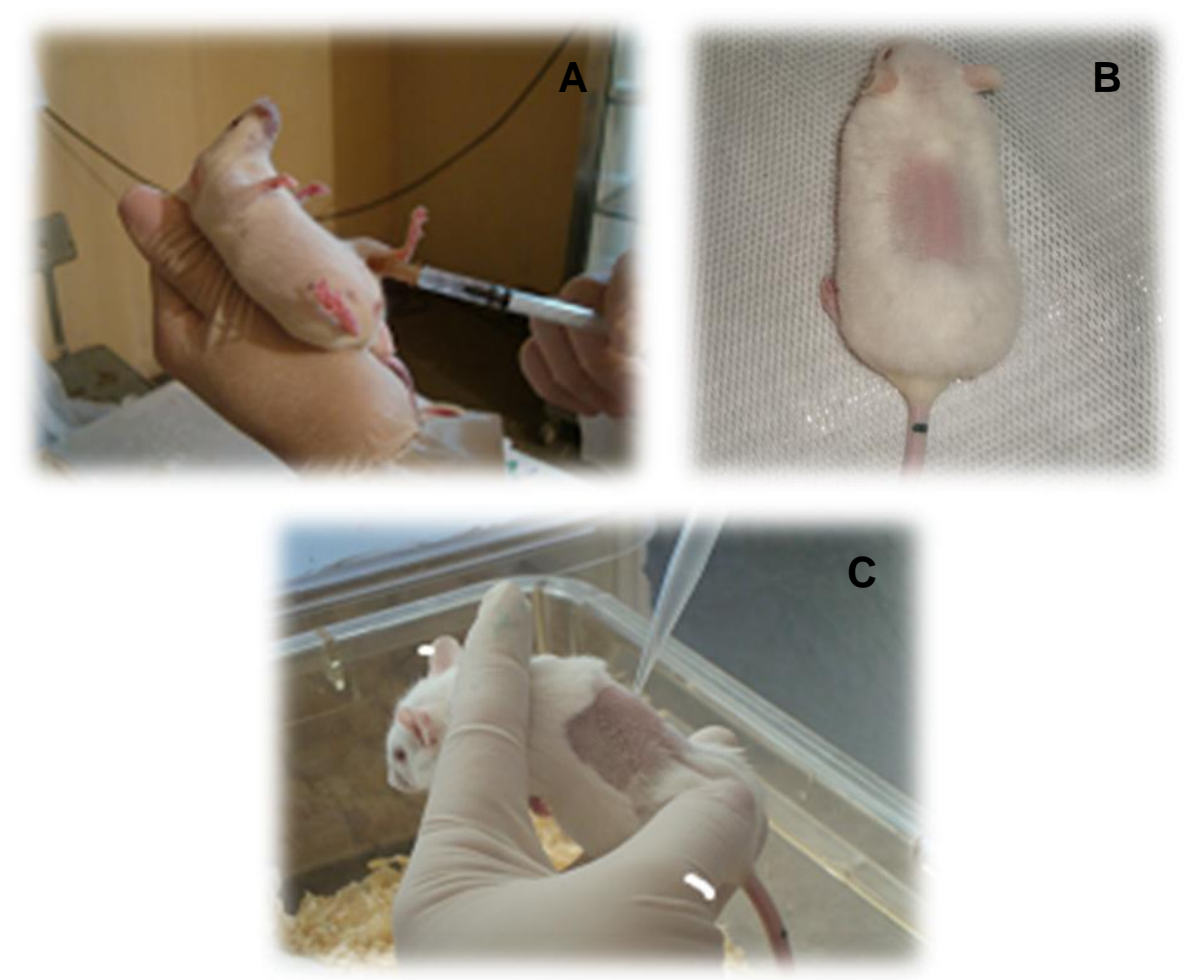

FIGURA 11: Imagens representativas da carcinogênese química. (A) anestesia, (B) dorso tricotomizado e $(C)$ aplicação tópica do carcinogênico.

Após uma semana da aplicação do DMBA, iniciou-se a segunda fase chamada de promoção, na qual $5 \mu \mathrm{g}$ de TPA(12-O-tetradecanoil-forbol-13 acetato) diluídos em $200 \mathrm{ml}$ de acetona foram aplicados duas vezes por semana, por um periodo de 28 semanas.Os animais controle receberam apenas aplicações de acetona.Todo o procedimento de aplicação foi realizado em uma capela para garantir a segurança do manipulador.

Após um período de vinte e oito semanas, obtivemos 25 animais com nódulos de tumores visíveis (FIGURA12). A morte de 50\% dos animais ocorreu devido ao longo tempo de indução e o estado debilitado que o tumor causa nos animais. 


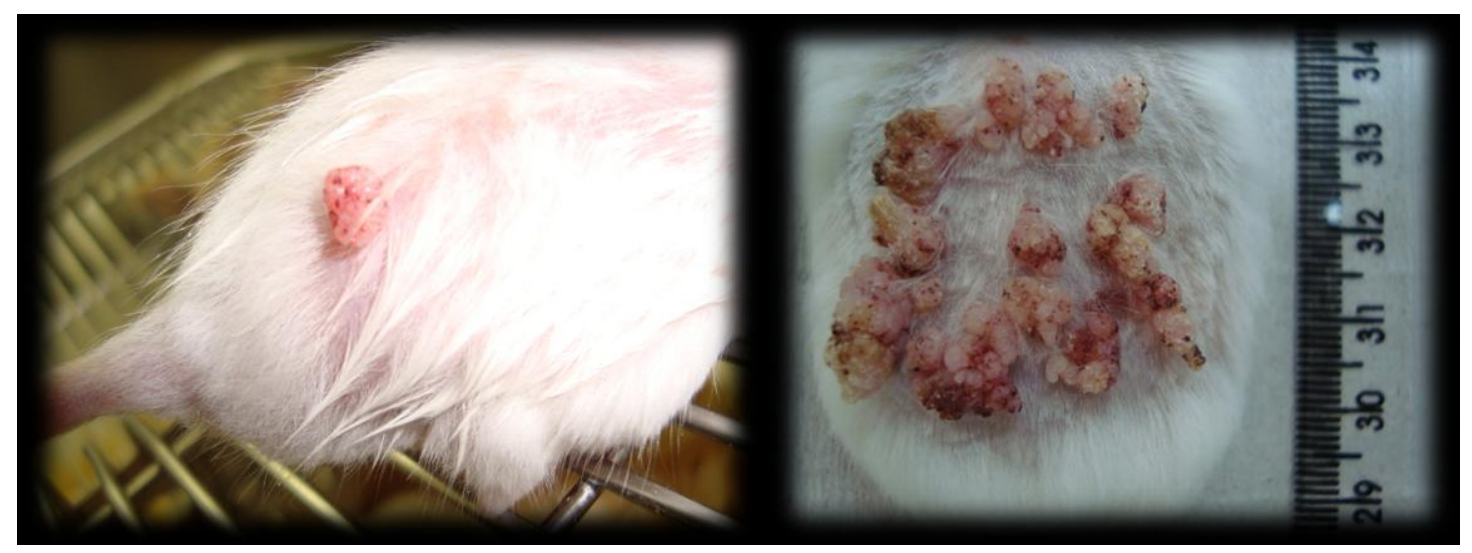

FIGURA 12: Camundongos com carcinoma espinocelular em diferentes estágios. A esquerda, 9 semanas e a direita 28 semanas após a carcinogênese química.

O modelo de carcinogênese química composta por duas etapas representa um modelo in vivo bem estabelecido para indução de tumor de pele. $O$ modelo permite avaliar mutações genéticas, estudar estratégicas de prevenção, progressão e até a extinção deste tumor, como é o caso do nosso estudo.

\subsection{Preparação da Pomada}

Os fotossensibilizadores utilizados neste estudo foram de uso tópico, sendo preparadas a base de lanolina e vaselina; apresentavam um aspecto homogêneo, inerte, inodoro e de boa consistência.

A concentração utilizada foi $20 \%$ para o ALA e $10 \%$ para o MEALA, sendo os demais componentes da formulação mantidos sob sigilo de patente (PINN0705591-9) desenvolvida no Laboratório de Biofotônica do Centro de Lasers e Aplicações do IPEN. A escolha por diferentes concentrações baseia- se em resultados prévios de tese de doutorado onde já foram testadas concentrações de ALA e MEALA em carcinoma espontâneo em felinos ${ }^{83,84}$. Além disso, há relatos na literatura de uso em paciente humano ALA à $20 \%{ }^{38,85,86}$. 
A opção pelo uso da pomada com concentrações diferentes, sendo menor para o MEALA, se deve também a propriedade lipofílica deste FFS, sendo assim sua penetração no tecido é maior.

As pomadas eram preparadas 24 horas antes do experimento, armazenadas em frascos escuros, vedada com parafilme (película flexível), embrulhada com papel alumínio e guardadas sob refrigeração a $4^{\circ} \mathrm{C}$ na geladeira até o momento de uso.

\subsection{Aplicação da Pomada}

Os animais foram distribuídos em sete grupos como mostra a TABELA 1, de forma sequencial, não randomizada. A aplicação da pomada foi feita mediante 0 uso de luvas de procedimento (suficientes para proteção do operador durante o manuseio do produto) e espátula de plástico descartável, sendo realizada sobre as lesões de tumor com uma margem adicional de aproximadamente cinco milímetros do tecido aparentemente normal. Todos os animais foram mantidos sedados e a sala experimental foi mantida com a luz apagada durante todo experimento. A aplicação da pomada foi repetida a cada 30 minutos, totalizando $5 \mathrm{~h}$ ou $5 \mathrm{~h} 30 \mathrm{~min}$, dependendo do fotossensibilizador, antes da irradiação para tratamento. Quando necessário, foi realizada uma anestesia complementar com meia dose de quetamina $(0,35 \mathrm{ml} / \mathrm{Kg})$ e xilasina $(0,20 \mathrm{ml} / \mathrm{Kg})$ via subcutânea. 
Tabela 1: Descrição dos Grupos

\begin{tabular}{|c|c|c|c|}
\hline Grupo & Tratamento & Descrição & Excitação \\
\hline Grupo 1 & Controle Negativo & Pele Sadia & $O C T$ \\
\hline Grupo 2 & Controle ALA & $\begin{array}{l}\text { Pele Sadia } \\
\text { ALA }\end{array}$ & $405 \mathrm{~nm}$ \\
\hline $\begin{array}{c}\text { Grupo } 3 \\
N=3\end{array}$ & Controle MEALA & $\begin{array}{c}\text { Pele Sadia } \\
\text { MEALA }\end{array}$ & $405 \mathrm{~nm}$ \\
\hline$\underset{N=5}{\text { Grupo }} 4$ & Neoplasia ALA & $\begin{array}{c}\text { Tecido } \\
\text { Neoplásico } \\
\text { ALA }\end{array}$ & $\begin{array}{c}405 \mathrm{~nm} \\
\text { OCT }\end{array}$ \\
\hline $\begin{array}{c}\text { Grupo } 5 \\
\mathrm{~N}=5\end{array}$ & Neoplasia MEALA & $\begin{array}{c}\text { Tecido } \\
\text { Neoplásico } \\
\text { MEALA }\end{array}$ & $\begin{array}{c}405 \mathrm{~nm} \\
\text { OCT }\end{array}$ \\
\hline$\underset{N=5}{\text { Grupo } 6}$ & PDT ALA & $\begin{array}{c}\text { Tecido } \\
\text { Neoplásico } \\
\text { ALA/PDT }\end{array}$ & $\begin{array}{c}630 \mathrm{~nm} \\
\text { OCT }\end{array}$ \\
\hline $\begin{array}{c}\text { Grupo } 7 \\
N=5\end{array}$ & PDT MEALA & $\begin{array}{c}\text { Tecido } \\
\text { Neoplásico } \\
\text { MEALA/PDT }\end{array}$ & $\begin{array}{c}630 \mathrm{~nm} \\
O C T\end{array}$ \\
\hline
\end{tabular}

\subsection{Espectroscopia de fluorescência}

Para medir a fluorescência das lesões utilizamos um espectrômetro portátil comercial (modelo HR4000(Ocean Optics, EUA) o qual conta com uma grade de difração de 4.600 linhas $/ \mathrm{mm}$, com resposta entre 200 e $1100 \mathrm{~nm}$, largura de banda de 0,3-10 nm e uma fenda de $100 \mu \mathrm{m}$. A resolução óptica calculada de $4,4 \mathrm{~nm}$. Para a conversão do sinal óptico para digital foi utilizado um detector CCD (Toshiba TCD1304AP).

A fonte de excitação utilizada foi um laser de diodo semicondutor de InGaAIN com o comprimento de onda de $405 \mathrm{~nm}$, e potencia máxima de $150 \mathrm{~mW}$ 
aferida com um detector (LM-2UV, Ser \# 0066E08R, Coherent, EUA) e por um medidor de energia (Power Energy Meter - Fieldmaster, Coherent, EUA). Este comprimento de onda $(\lambda)$ foi utilizado por ser coincidente com a máxima absorção da protoporfirina IX (PPIX). A fibra acoplada ao espectrômetro foi R 600-7-UV/125F (Ocean Optics, EUA), caracterizada por ser em forma de Y. Em uma das extremidades desta fibra é acoplado o laser de excitação que conduz o feixe até a segunda extremidade a qual faz com que $0 \lambda$ de excitação incida no tecido. Esta extremidade tem outras seis fibras ópticas acopladas ao redor que coletam a fluorescência emitida do tecido e a conduzem até a terceira extremidade que se conecta ao espectrofotometro. Um filtro passa-alta comprimentos de onda $(\lambda>590 \mathrm{~nm})$ foi inserido no arranjo óptico antes da entrada do espectrofotômetro para atenuar a intensidade do feixe laser de excitação. A FIGURA13 representa 0 arranjo óptico utilizado.

O arranjo óptico foi calibrado tomando como referência o espectro de uma lâmpada halógena branca (HL-2000-FHSA, Mikropack) para assegurar a detecção reproduzível do comprimento de onda e intensidade. O padrão de aquisição dos espectros utilizado foi: tempo de integração de 500 ms e 5 scans. 


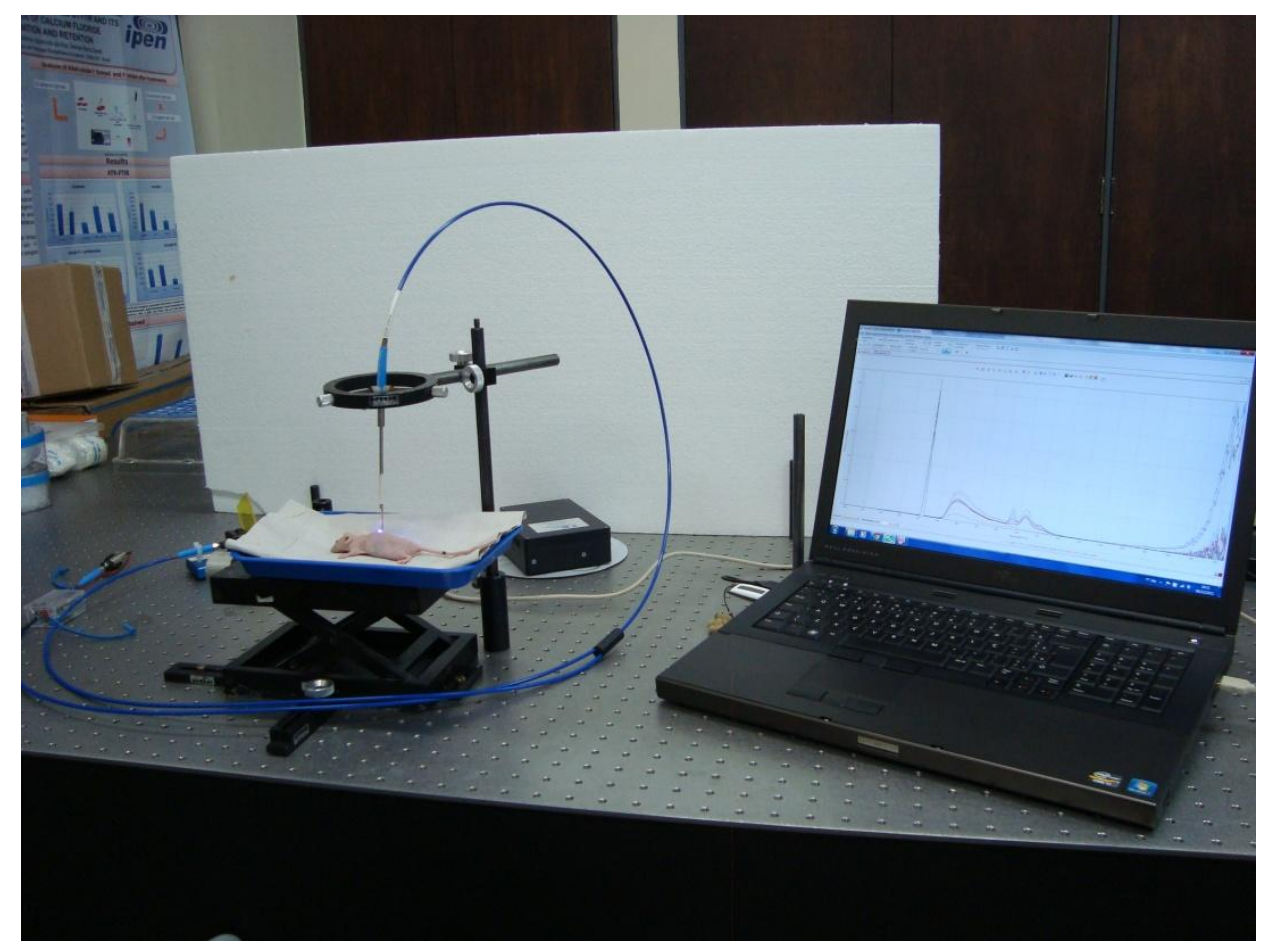

FIGURA 13: Arranjo óptico da espectroscopia de fluorescência para monitoramento da fluorescência emitida pela PPIX induzida pelos FFS no tecido neoplásico.

Os animais foram devidamente anestesiados, conforme descrito, para a aplicação do fotossensibilizador, e em seguida foi mensurada a fluorescência emitida da pele normal e da lesão respectivamente grupos 2, 3, 4 e 5, todos os animais foram mantidos no escuro durante e após os procedimentos. As leituras geraram espectros, conforme a FIGURA 14, que foram armazenadas no computador por meio do Programa Spectrasuite (Ocean Optics, EUA), para serem tratados e nos fornecer dados quantitativos dos resultados obtidos. 


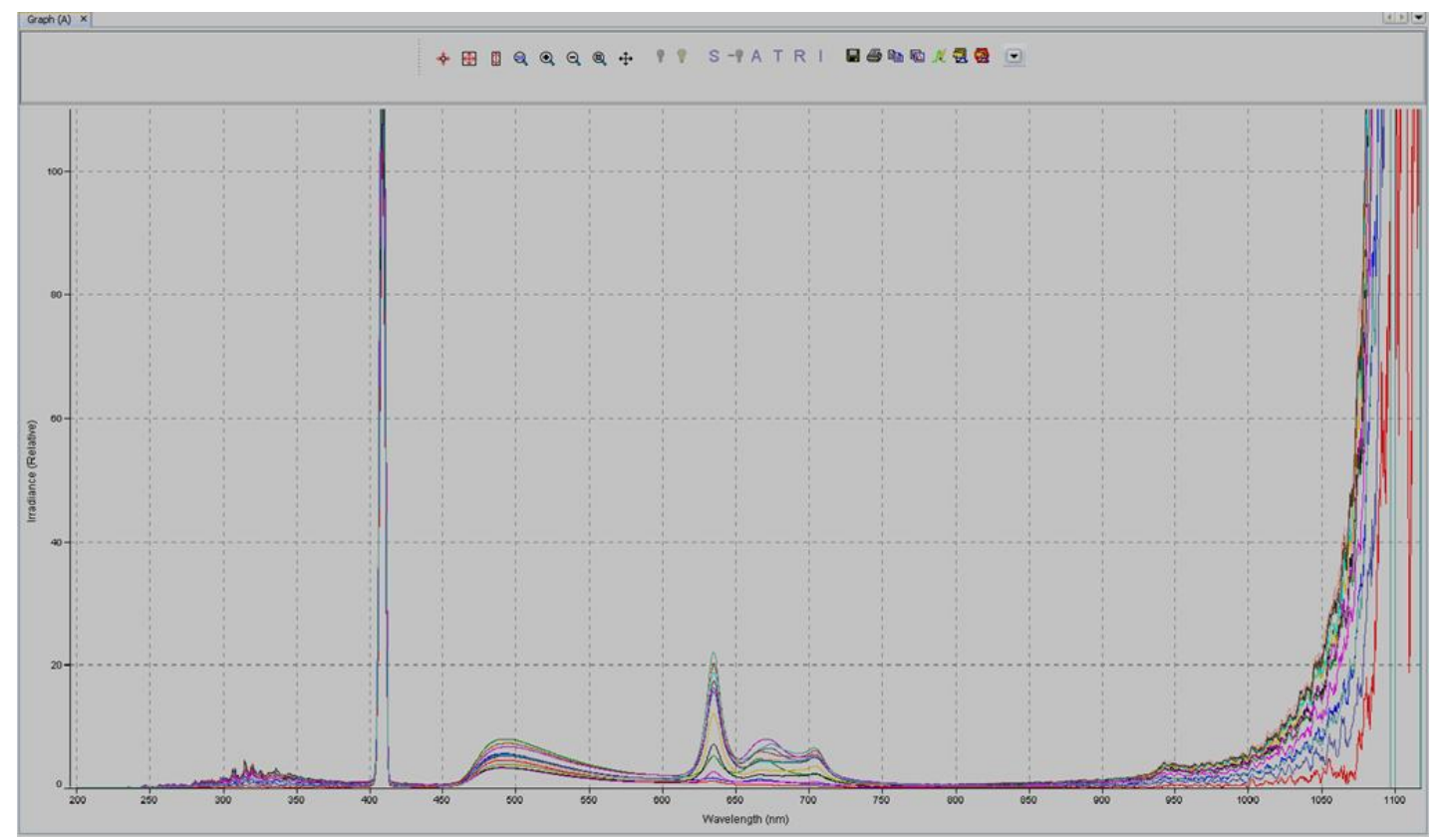

FIGURA 14: Espectro representativo gerado nas leituras de fluorescência da PPIX.

O sinal de fluorescência em $\lambda=635 \mathrm{~nm}$ do espectro, emitido pela PPIX presente no tecido, foi normalizado pela intensidade do laser de excitação ( $\lambda=405 \mathrm{~nm})$ dos espectros, a fim de remover efeitos de distância ou angulação entre a ponta de prova e o tecido alvo, permitindo assim comparações ao longo do tempo.

A normalização consistiu na divisão de todos os pontos do espectro pela intensidade do pico de excitação, após esta normalização foi realizada a média da intensidade máxima dos espectros de cada grupo para minimizar possíveis erros das variações biológicas do próprio tecido. Este procedimento permite comparar a incorporação dos fotossensibilizadores e o seu pico de máxima incorporação no tecido normal e neoplásico.

\subsection{Terapia Fotodinâmica}

\subsubsection{Procedimento de Irradiação}


Antes do procedimento de iluminação da área a ser tratada, o excedente da pomada nas lesões foi removido com o auxilio de uma gaze umedecida em água. Para a realização da terapia fotodinâmica foi utilizado um protótipo composto por um cluster de 30 LED. Esse protótipo contém as seguintes especificações: potência de $180 \mathrm{~mW}$, densidade de potência de $5 \mathrm{~mW} / \mathrm{cm}^{2}$ e comprimento de onda de $630 \mathrm{~nm}$. Durante toda a exposição à terapia o operador e pessoas presentes no laboratório utilizaram óculos de proteção adequados ao comprimento de onda da luz emitido pelos LED e a sala experimental foi mantida com a luz apagada, para não interferir no tratamento. A densidade de energia utilizada para a terapia foi de $12 \mathrm{~J} / \mathrm{cm}^{2}$, sendo o tempo de irradiação calculado para essa fluência de 40 minutos (FIGURA15) ${ }^{83}$.

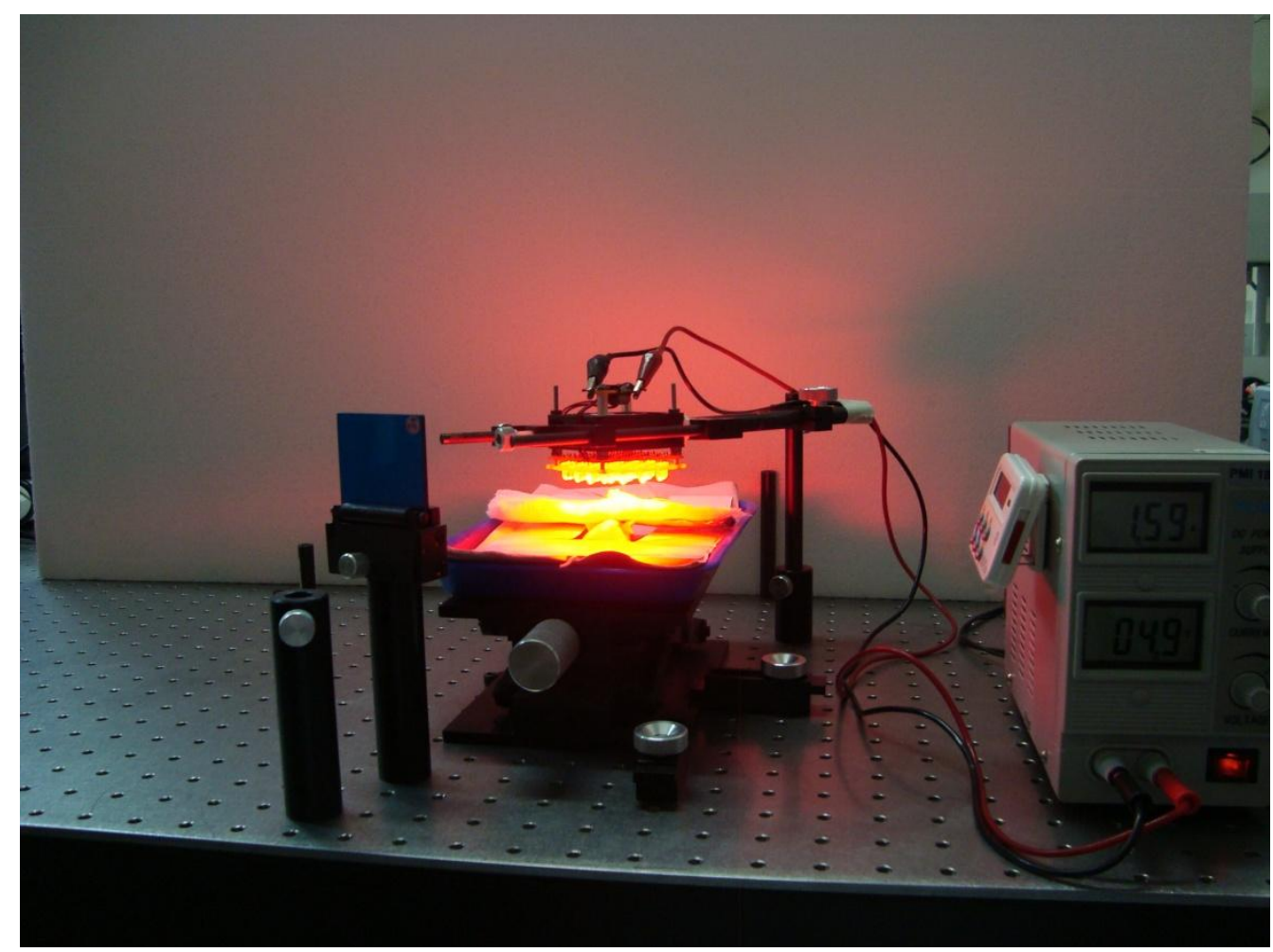

FIGURA 15: Irradiação das lesões com o Cluster de LED, $\lambda=630 \mathrm{~nm}$.

\subsection{Tomografia por Coerência Óptica}

As análises por tomografia de coerência óptica foi realizada nos grupos 1,4, 5 e grupo 6 e 7 após 10 e 20 dias da PDT. O sistema de OCT utilizado neste 
estudo (OCP930SR, Thorlabs Inc., USA) disponível no laboratório de Tomografia Óptica do Centro de Lasers e Aplicações - IPEN-CNEN/SP (FIGURA16), possui fonte de LED superluminescente, com comprimento de onda $930 \mathrm{~nm}$, largura de banda de $100 \mathrm{~nm}$, e resolução axial calculada $1,38 \mu \mathrm{m}$ e lateral de $6,1 \mu \mathrm{m}$. As imagens geradas possuem dimensão de $1000 \times 512$ pixels, correspondendo a um alcance lateral de 5,0 $\mathrm{mm}$ e uma profundidade axial de $1,5 \mathrm{~mm}$.

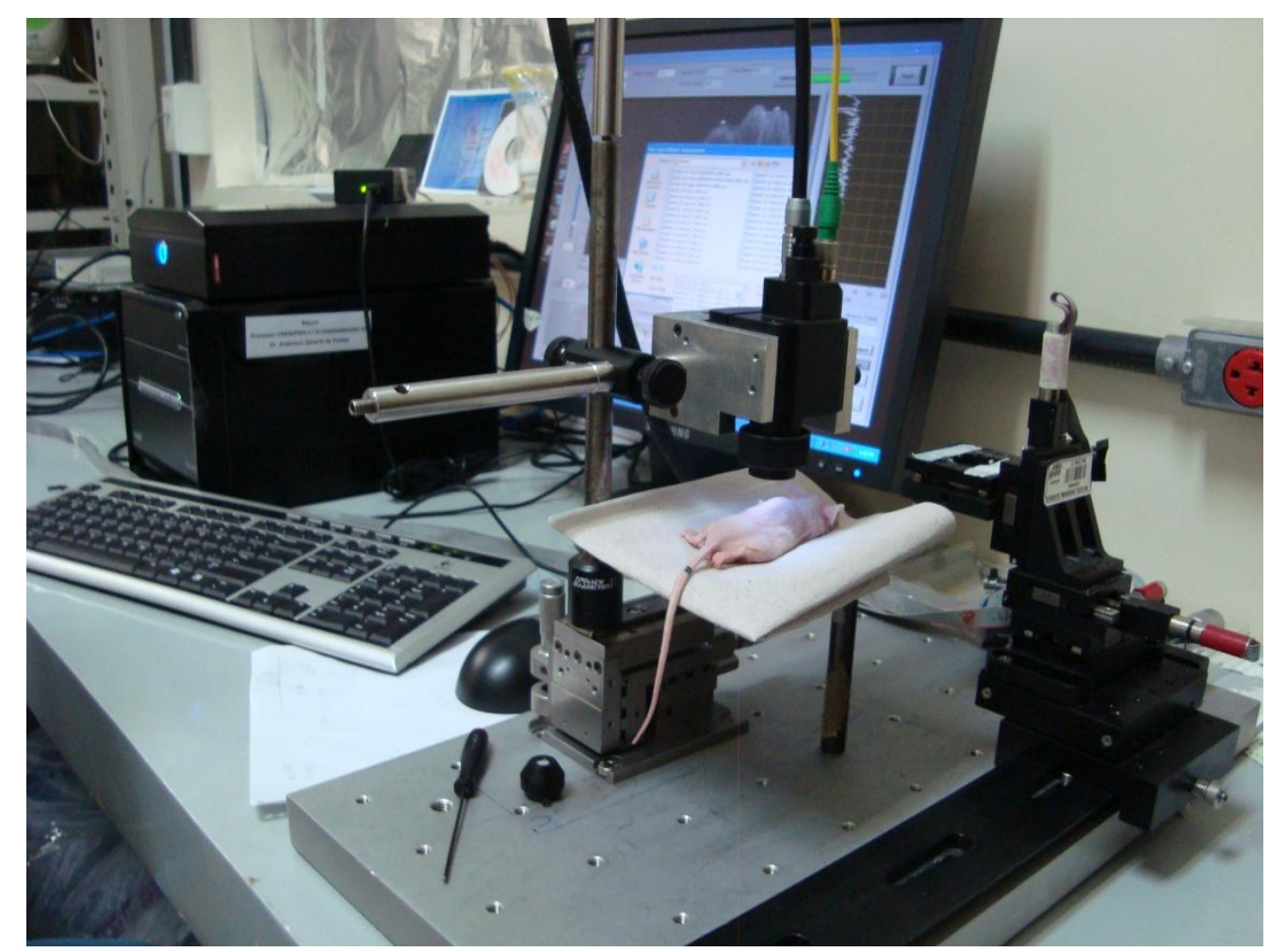

FIGURA 16: Sistema de OCT utilizado para tomada de dados da pele dos grupos controle e experimentais.

Para o cálculo do coeficiente de atenuação óptico, foi utilizado um modelo simples de decaimento exponencial da intensidade da luz detectada (retroespalhada), de acordo com a equação:

$$
I(Z)=I_{0} e^{-2 \alpha z}+c
$$


onde, I representa o valor da intensidade detectada, $I_{0}$ é o valor da intensidade da fonte luminosa, $\alpha$ é o coeficiente de atenuação óptico total, z é a profundidade analisada, $C$ é uma constante utilizada em decorrência do ruído de fundo do sinal e $e^{-2 a}$ é a função matemática exponencial $\left.\right|^{87}$.

Um programa desenvolvido pelo mesmo laboratório permite selecionar uma região de interesse ( $\mathrm{ROI}$ - Region Of Interest) com o uso dos delimitadores (linhas branca e vermelha) na parte superior da FIGURA 17, sendo que a região selecionada aparece em destaque no canto inferior, facilitando a localização da neoplasia e a exclusão dos folículos pilosos que interferem no sinal óptico. As linhas delimitadoras branca e vermelha na região inferior da FIGURA 17 permitem escolher a que profundidade da amostra será realizada a análise. As análises foram realizadas, em três faixas de profundidades, 0 a $400 \mu \mathrm{m}, 20$ a $400 \mu \mathrm{m}$ e 10 a $300 \mu \mathrm{m}$.

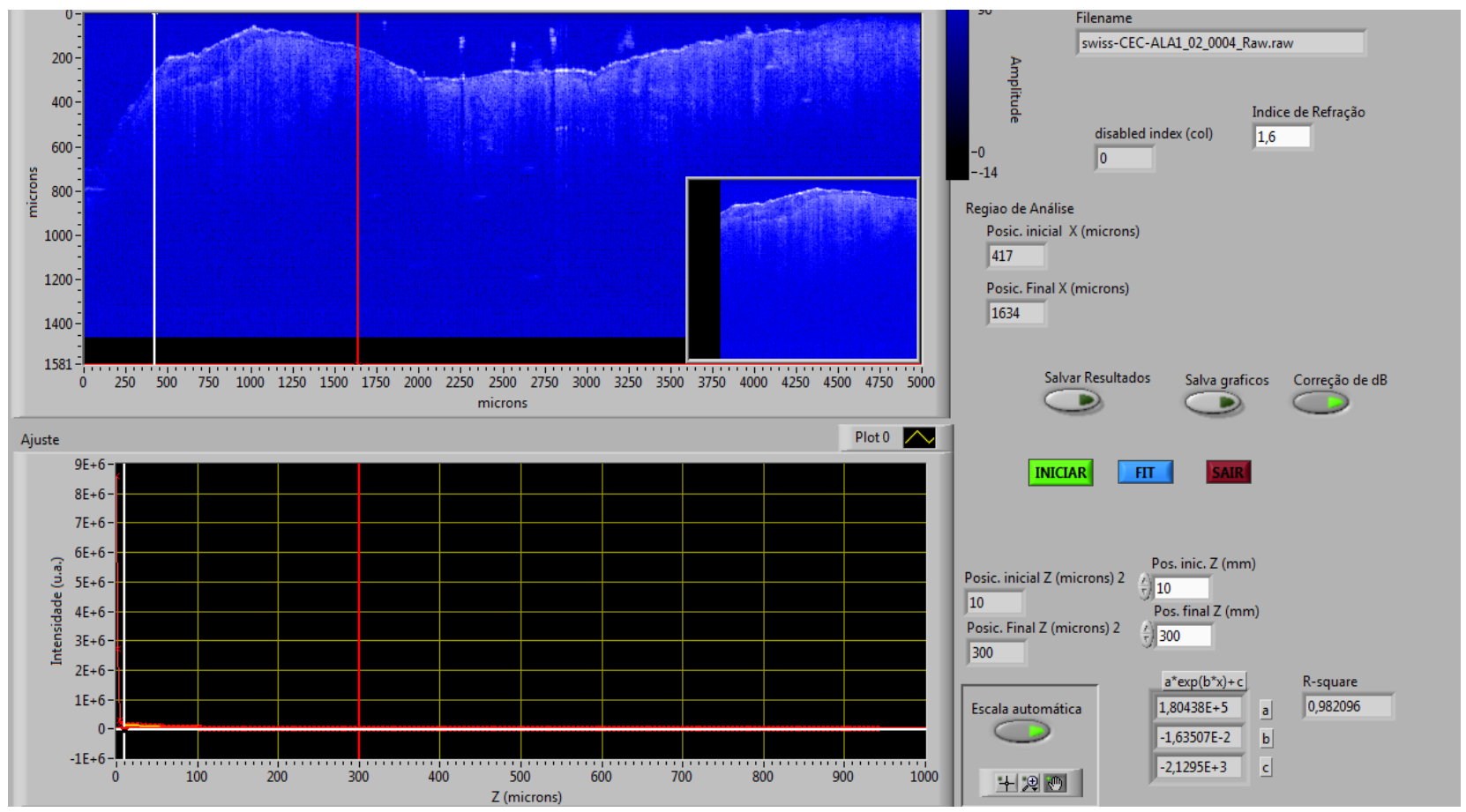

FIGURA 17: Interface do Programa utilizado para análise das imagens de OCT. 
O perfil de decaimento utilizado para a análise, curva apresentada na parte inferior da FIGURA 17, é obtida pela média aritmética dos valores de espalhamento de todas as colunas da imagem de OCT na ROI (entre as linhas branca e vermelha na parte superior da FIGURA17).

O coeficiente de atenuação óptico de cada amostra foi obtido a partir da média aritmética dos valores de coeficiente de atenuação provenientes de cada uma das imagens analisadas. 


\section{Resultados}

\subsection{Monitoração da fluorescência emitida pela PPIX}

Por meio de espectroscopia de fluorescência verificamos o tempo em que ocorre a máxima emissão da protoporfirina IX nos fotossensibilizadores ALA e MEALA, molécula que é fotossensível à luz e cuja produção ou acúmulo no local de aplicação da pomada é induzida pelos fotossensibilizadores ALA e MEALA. Sendo assim a ação da $P D T$ depende da concentração de protoporfirina IX no local a ser irradiado.

O comprimento de onda de interesse avaliado neste trabalho foi o $635 \mathrm{~nm}$,

proveniente da protoporfirina IX por ser o mais intenso. Após a normalização já descrita no item 4.4, para analisar a diferença de intensidade deste $\lambda$, calculamos uma média de cada ponto medido dos espectros nos grupo 2 a 5 em função do tempo.

Os gráficos da intensidade relativa do pico da PPIX pelo tempo são apresentados na FIGURA 18 (G2-controle ALA), FIGURA 19 (G3-controle MEALA). 


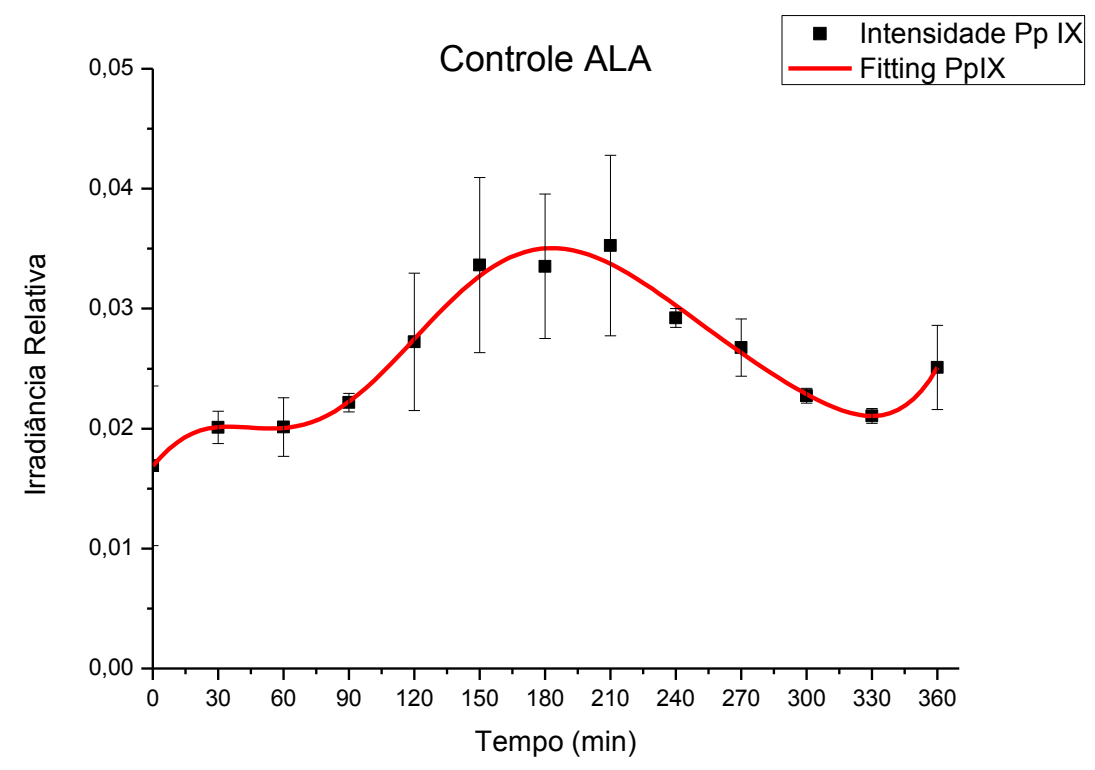

FIGURA 18: Intensidade média e erro padrão da fluorescência medida em $\lambda=635 \mathrm{~nm}$ (PPIX) do grupo controle fotossensibilizado pelo ALA (Grupo 2) em função do tempo.

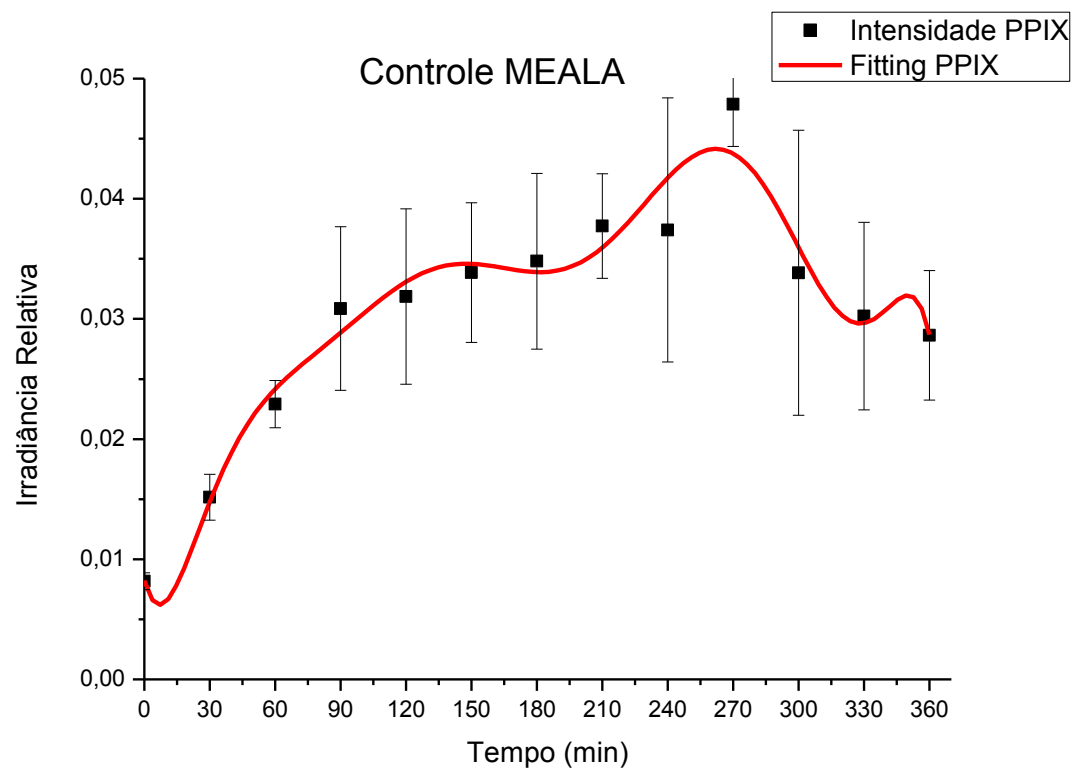

FIGURA 19: Intensidade média e erro padrão da fluorescência medida em $\lambda=635 \mathrm{~nm}$ (PPIX) do grupo controle fotossensibilizado pelo MEALA (Grupo 3) em função do tempo. 
Os tempos para os quais foram registradas a máxima intensidade de fluorescência foram 180 e 270 minutos para os fotossensibilizadores ALA e MEALA respectivamente. O grupo controle MEALA (G3) apresentou uma emissão secundária em 90 minutos o que não ocorreu com o grupo controle ALA (G2), evidenciando uma maior penetração deste fotossensibilizador.

As FIGURAS 20 e 21 representam a monitoração da intensidade relativa de emissão dos tecidos neoplásicos (G4 e G5). Em ambos foi realizada a normalização e a média dos espectros em função do tempo.

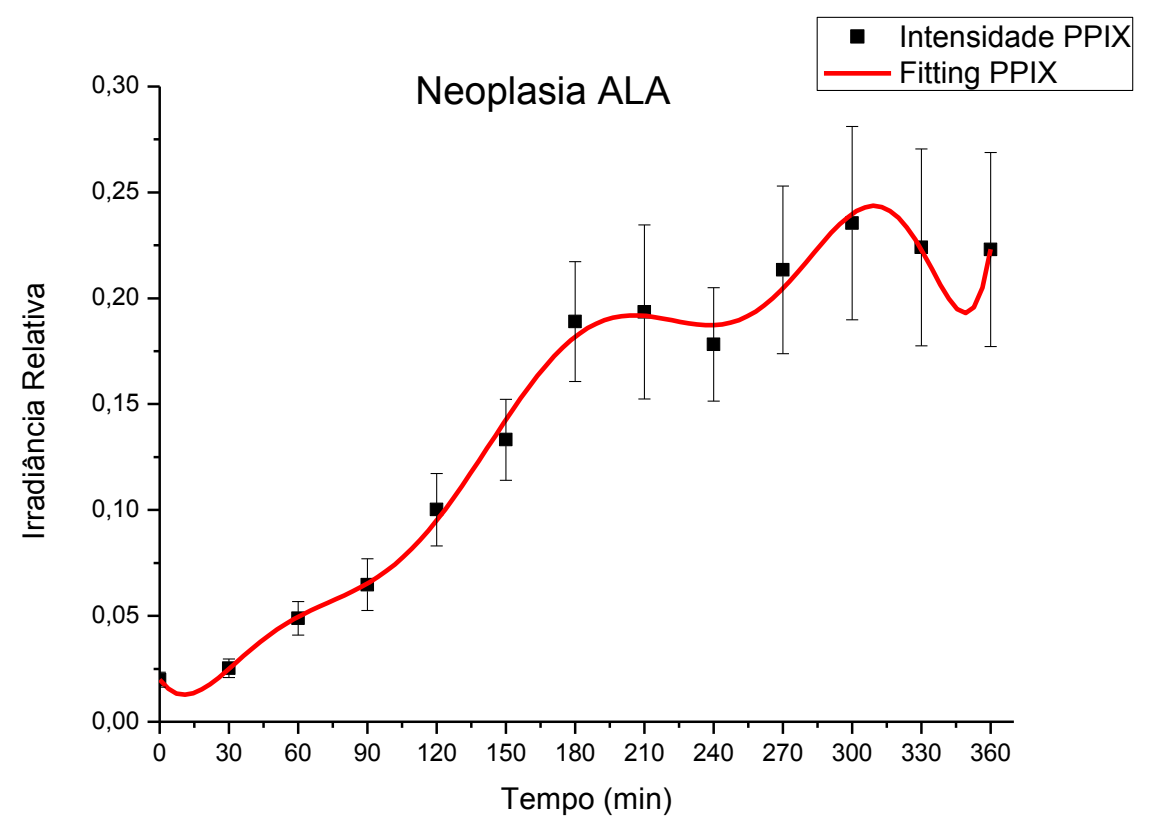

FIGURA 20: Intensidade média da fluorescência medida em $\lambda=635 \mathrm{~nm}$ (PPIX) do grupo neoplásico fotossensibilizado pelo ALA (Grupo 4) em função do tempo. 


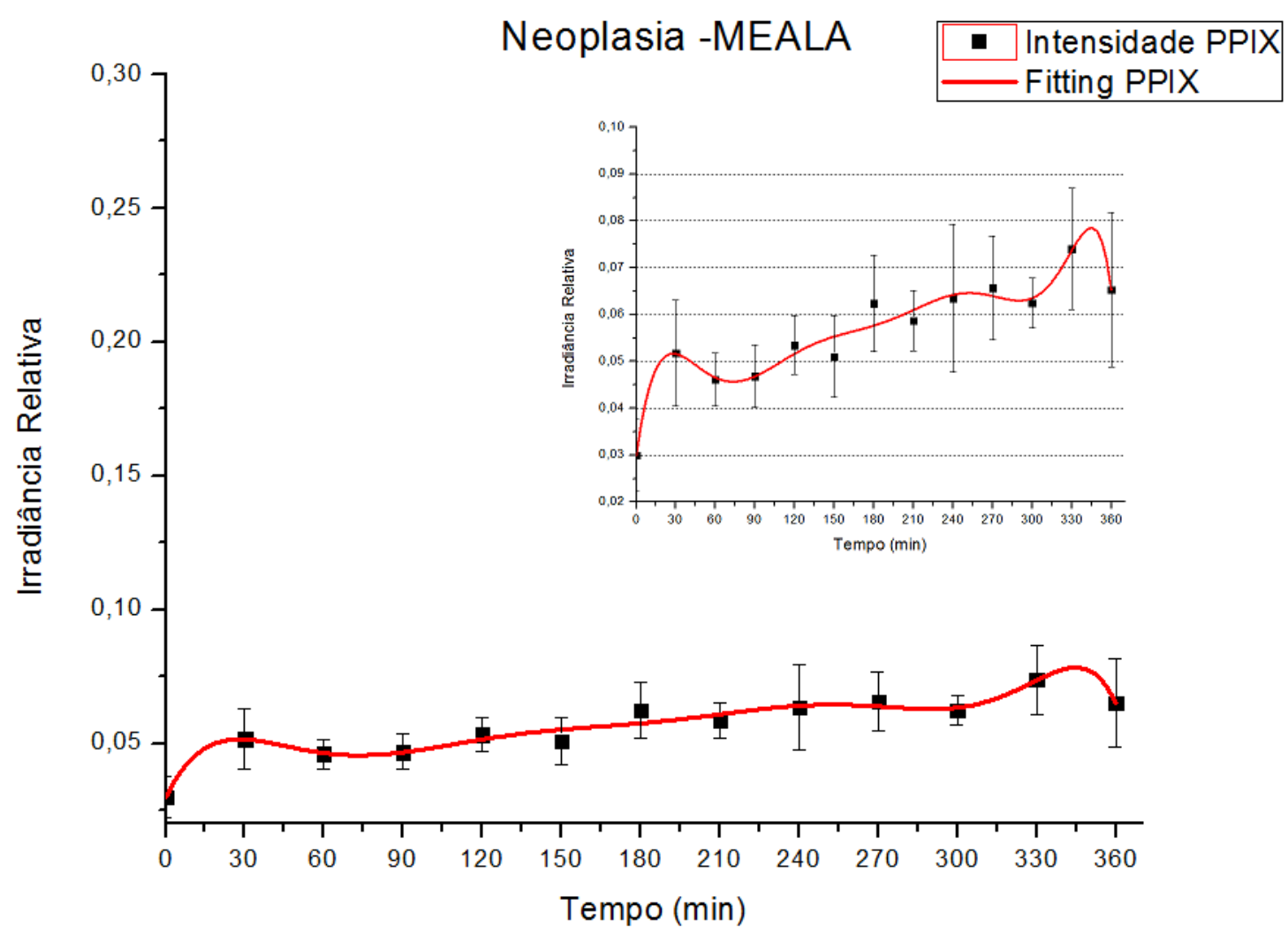

FIGURA 21: Intensidade média da fluorescência medida em $\lambda=635 \mathrm{~nm}$ (PPIX) do grupo neoplásico fotossensibilizado pelo MEALA (Grupo 5) em função do tempo. A figura acima utiliza uma escala maior para evidenciar os picos de maior intensidade.

Avaliando os resultados dos grupos 4 e 5 que apresentavam neoplasias malignas, o tempo para qual ocorre a maior intensidade relativa de fluorescência foi 300 minutos para o ALA e 330 minutos após a aplicação do fotossensibilizador MEALA. A intensidade de fluorescência do grupo ALA foi quase o triplo em relação ao grupo na qual foi utilizado o MEALA como fotossensibilizador. Esta maior produção de PPIX pelo ALA também foi evidenciada em demais trabalhos ${ }^{88,89,90,93}$. Isso ocorreu possivelmente devido à diferença na concentração dos fotossensibilizadores que foi o dobro para o ALA e o metil éster do ácido aminolevulínico possui maior penetração nas lesões neoplásicas devido a suas propriedades lipofílicas, uma vez que a medida foi realizada na superfície da lesão é provável que não tenha sido detectado o sinal de fluorescência da protoporfirina presente mais internamente ao tecido neoplásico. Uma emissão secundária em 30 
minutos após a aplicação do FFS esteve presente na evolução de todos os animais monitorados. A observação deste pico de emissão após 30 min pode ser promissora para customização do tempo de inicio para a terapia fotodinâmica, porém mais estudos são necessários para validar esta hipótese.

Os gráficos das FIGURAS 22 e 23 representam uma comparação dos grupos controles G2 e G3 com os grupos com neoplasias G4 e G5. A fim de evidenciar a forte incorporação dos fotossensibilizadores nas lesões.

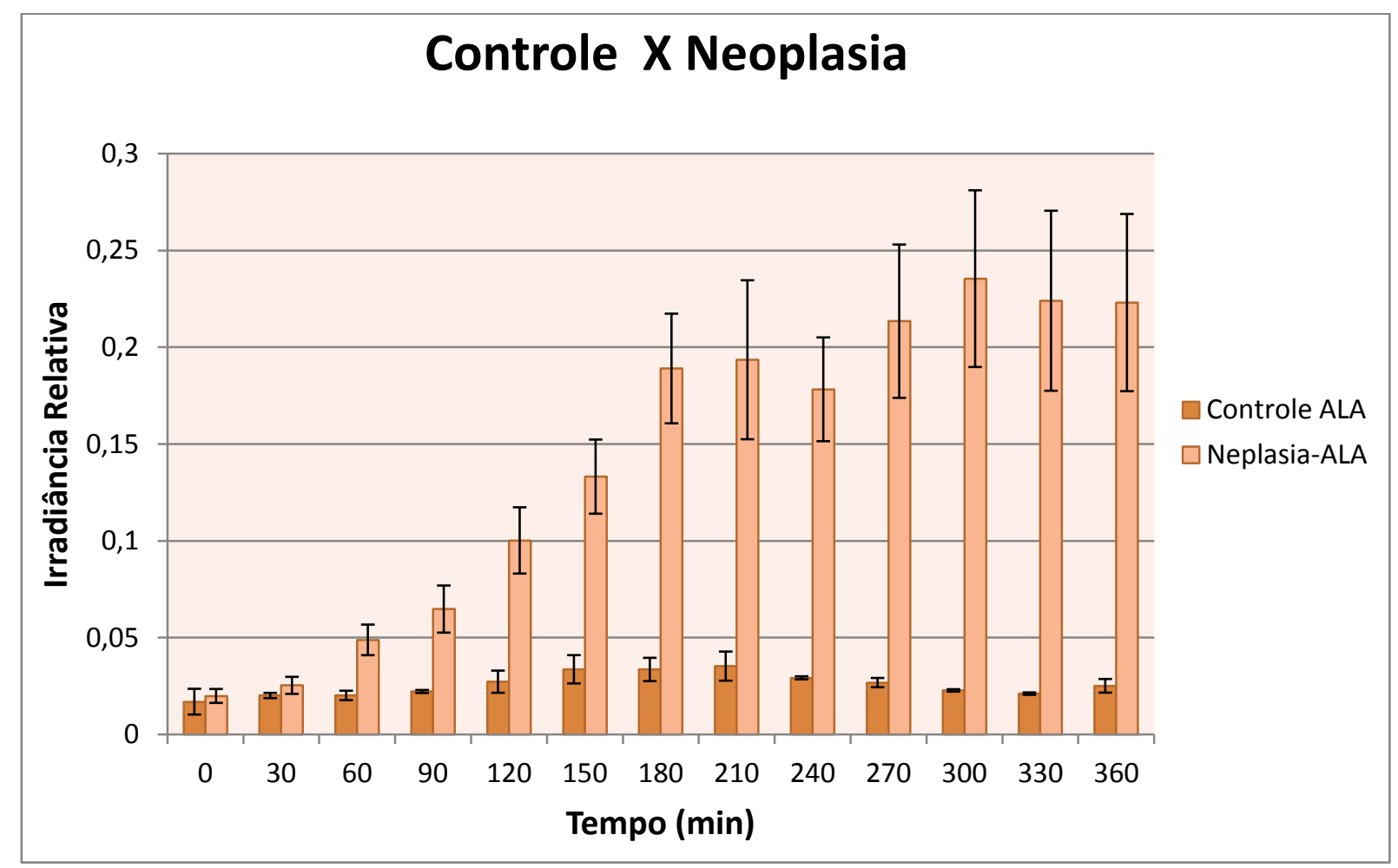

FIGURA 22: Correlação da irradiância entre os G2 (controle) e G4 (neoplasia) na incorporação do fotossensibilizador ALA. As barras representam o erro padrão. 
A análise estatística foi realizada utilizando-se a análise de variância com dois fatores (ANOVA Two-Way, com 5\% de significância, sendo a comparação entre os grupos foram realizadas com o Teste de Bonferroni, também com $5 \%$ de significância. Os valores de $\mathrm{p}$ encontrados na comparação entre os grupos são apresentados na Tabela 2 e Tabela 3.

Tabela 2 - Valores de $p$ encontrados com o teste de BONFERRONI na comparação do grupo controle $X$ grupo neoplasia com FFS ALA.

\begin{tabular}{c|c}
\hline $\begin{array}{c}\text { Cont. ALA vs Neoplasia } \\
\boldsymbol{A L A} \text { ( } \min )\end{array}$ & Valor de $\boldsymbol{p}$ \\
\hline 0 & $\mathrm{~ns}$ \\
30 & $\mathrm{~ns}$ \\
60 & $\mathrm{~ns}$ \\
90 & $\mathrm{~ns}$ \\
120 & $\mathrm{~ns}$ \\
150 & $0,001-00,1$ \\
180 & $0,001-00,1$ \\
210 & $0,001-00,1$ \\
240 & $<0,001$ \\
270 & $<0,001$ \\
300 & $<0,001$ \\
330 & $<0,001$ \\
360 &
\end{tabular}


Nos primeiros intervalos de tempo 0 a 150 minutos, não houve diferença estatística entre G2 e G4, nos tempos de 180 a 240 min houve diferença com $p>0,001$ e nos tempos de 270 a 360 min foi observada uma diferença significativa de $p<0,001$.

A irradiância relativa foi maior para 0 grupo com neoplasia fotossensibilizado com ALA em todos os intervalos de tempo monitorados.

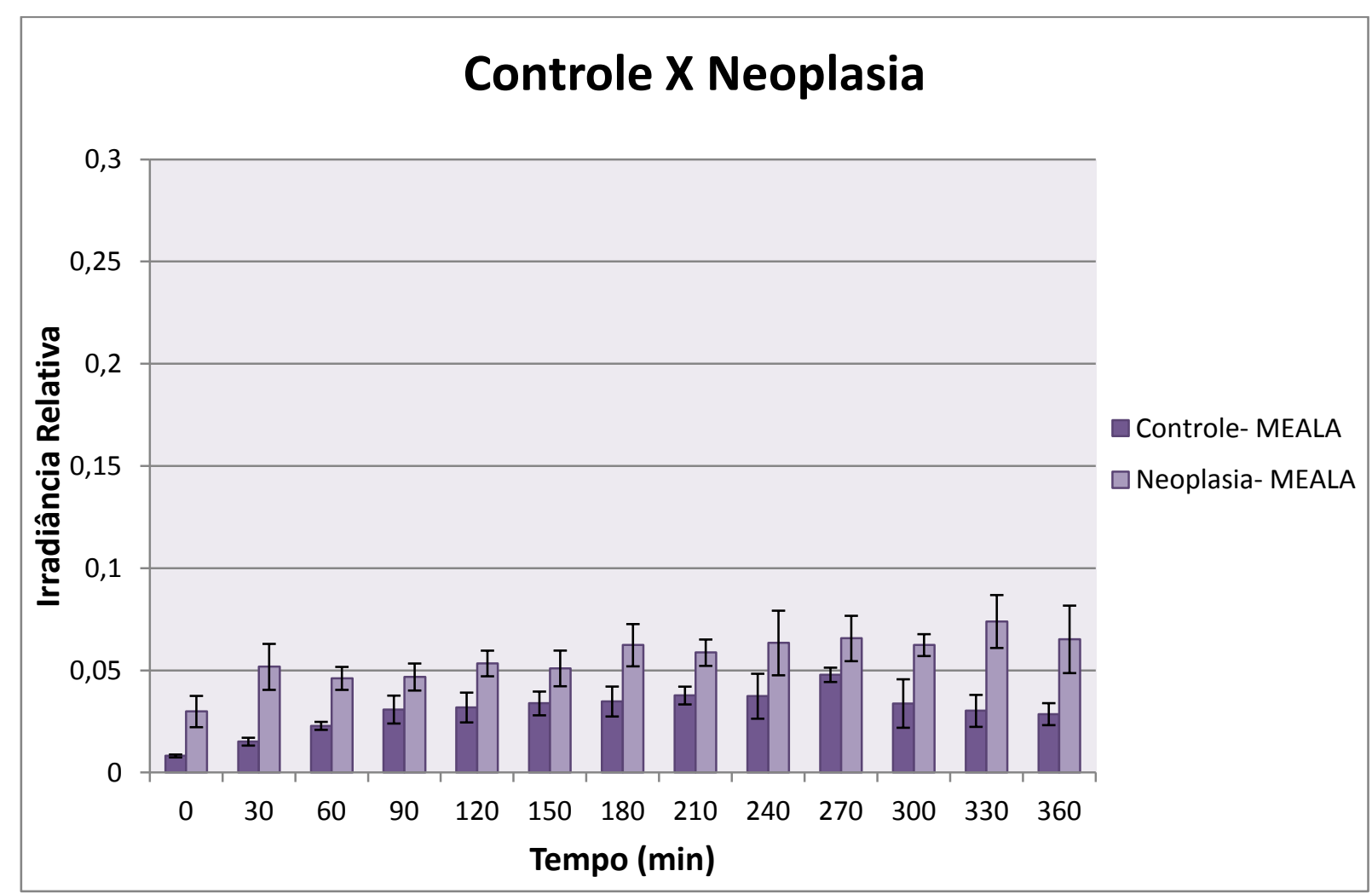

FIGURA 23: Correlação da irradiância entre os G3 (controle) e G5 (neoplasia) na incorporação do fotossensibilizador MEALA. As barras representam o erro padrão. 
Tabela 3 - Valores de $p$ encontrados com o teste de BONFERRONI na comparação do grupo controle $\mathrm{X}$ grupo neoplasia com FFS MEALA.

\begin{tabular}{c|c}
\hline $\begin{array}{c}\text { Cont. MEALA vs Neoplasia } \\
\text { MEALA ( } \text { min) }\end{array}$ & Valor de $\boldsymbol{p}$ \\
\hline 0 & ns \\
30 & ns \\
60 & ns \\
90 & ns \\
120 & ns \\
150 & ns \\
180 & ns \\
210 & ns \\
240 & ns \\
270 & ns \\
300 & ns \\
330 & $0,01-0,05$ \\
360 & ns \\
\hline
\end{tabular}

Nos grupos G3 e G5 que utilizaram o MEALA como fotossensibilizador, somente no tempo de 330 minutos houve diferença estatisticamente significante com $p$ entre 0,01 e 0,05 .

Quando comparamos a intensidade de fluorescência relativa dos grupos controles com os grupos que apresentavam lesões neoplásicas, observamos uma diferença na intensidade e no tempo de maior intensidade de fluorescência para 
ambos os grupos. Outros estudos ${ }^{91,92,93}$ também têm relatado esta maior intensidade de concentração da PPIX em tecidos neoplásicos, sugerindo que este tecido possui sua permeabilidade alterada em relação à pele sadia, favorecendo assim a penetração dos fotossensibilizadores no tecido. Esta característica é de grande importância para a terapia fotodinâmica de tumores, pois demonstra uma grande seletividade por células neoplásicas provocando assim uma quantidade menor de efeitos deletérios ou morte celular em tecido normal. Sabendo que o máximo da intensidade de fluorescência das células sadias ocorre mais precocemente em relação ao tecido neoplásico, é esperada uma maior seletividade e eficiência para o tratamento da terapia fotodinâmica neste tipo de tecido.

\subsection{Avaliações Clínicas}

A fim de verificar o efeito do tratamento uma avaliação clínica com o calculo da área das lesões, por meio do programa Image J, antes e após a PDT foi realizada nos grupos que foram submetidos a terapia fotodinâmica.

A FIGURA 24 ilustra a evolução clínica da neoplasia maligna, nos vários momentos 0,10 e 20 dias. $O$ percentual de redução das áreas das lesões em 10 dias e 20 dias após a PDT é apresentada graficamente na Figura 25. 

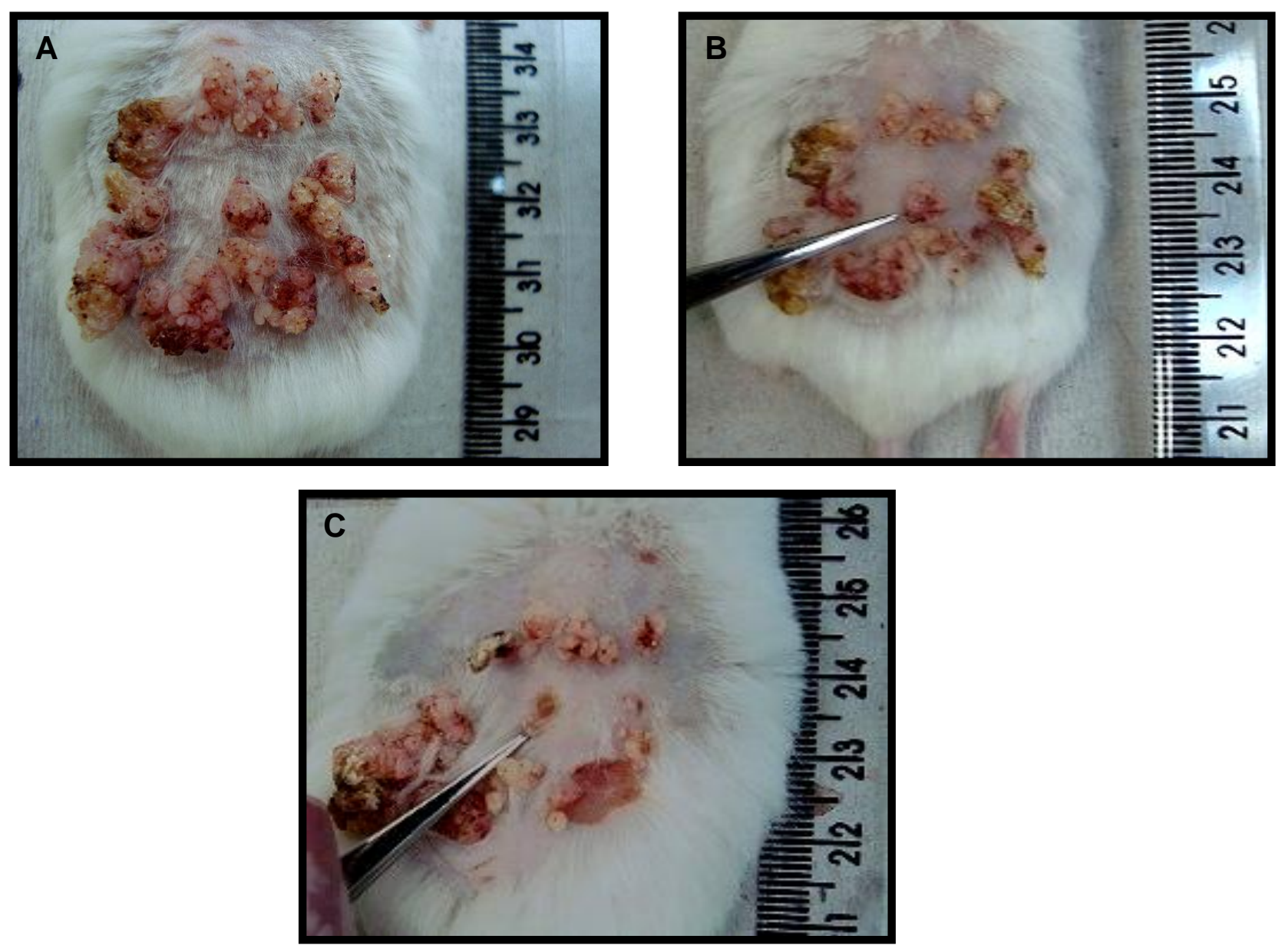

FIGURA 24: Imagens representativas da neoplasia maligna de pele induzida em camundongos: (A) antes da PDT (dia 0); (B) 10 dias após PDT; (C) 20 dias após PDT com ALA. 

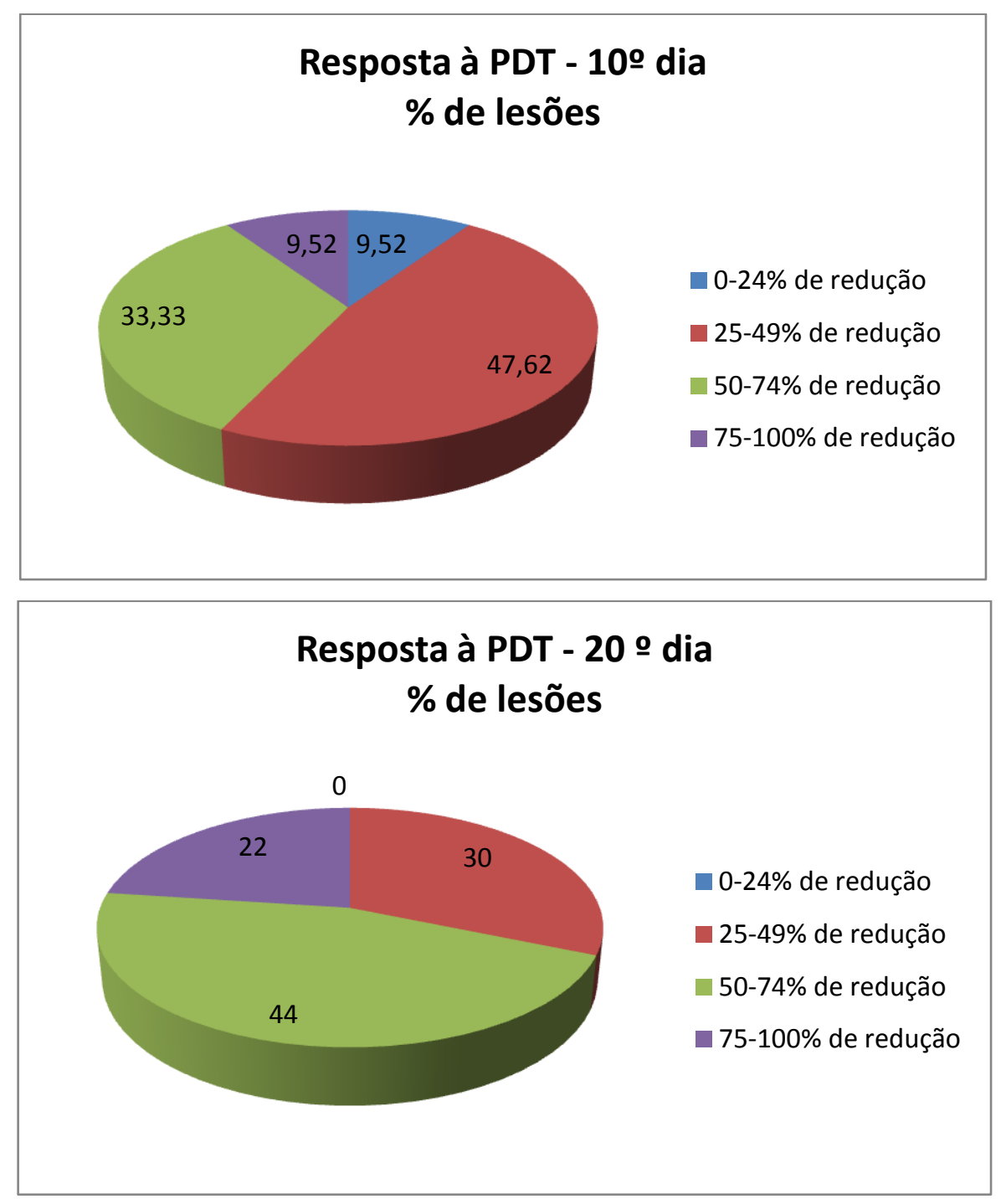

FIGURA 25: Resposta à $P D T$ em percentual de lesões com redução de área. Resposta de ambos os tratamentos após 10 e 20 dias.

De acordo com resultados representados na FIGURA 24 e FIGURA 25 foi possível verificar que ocorreu resposta positiva em todas as lesões submetidas a PDT. A FIGURA 25 mostra que no periodo 0 a 10 dias houve uma redução entre 25 a $49 \%$ em $47 \%$ das lesões e uma redução entre 50 a $74 \%$ em $33 \%$ das lesões. Este percentual foi alterado, no periodo de 0 à 20 dias, para 50 à $74 \%$ de redução em $44 \%$ das lesões e 75 e $100 \%$ de redução em $22 \%$ de todas as lesões após 0 tratamento com a $P D T$. 
Para verificar a resposta de redução das área das lesões em função do fotossensibilizador utilizado no tratamento, foi realizada uma quantificação do percentual de redução em função do fotossensibilizador utilizado nos tempos de $10 \mathrm{e}$ 20 dias após o tratamento.

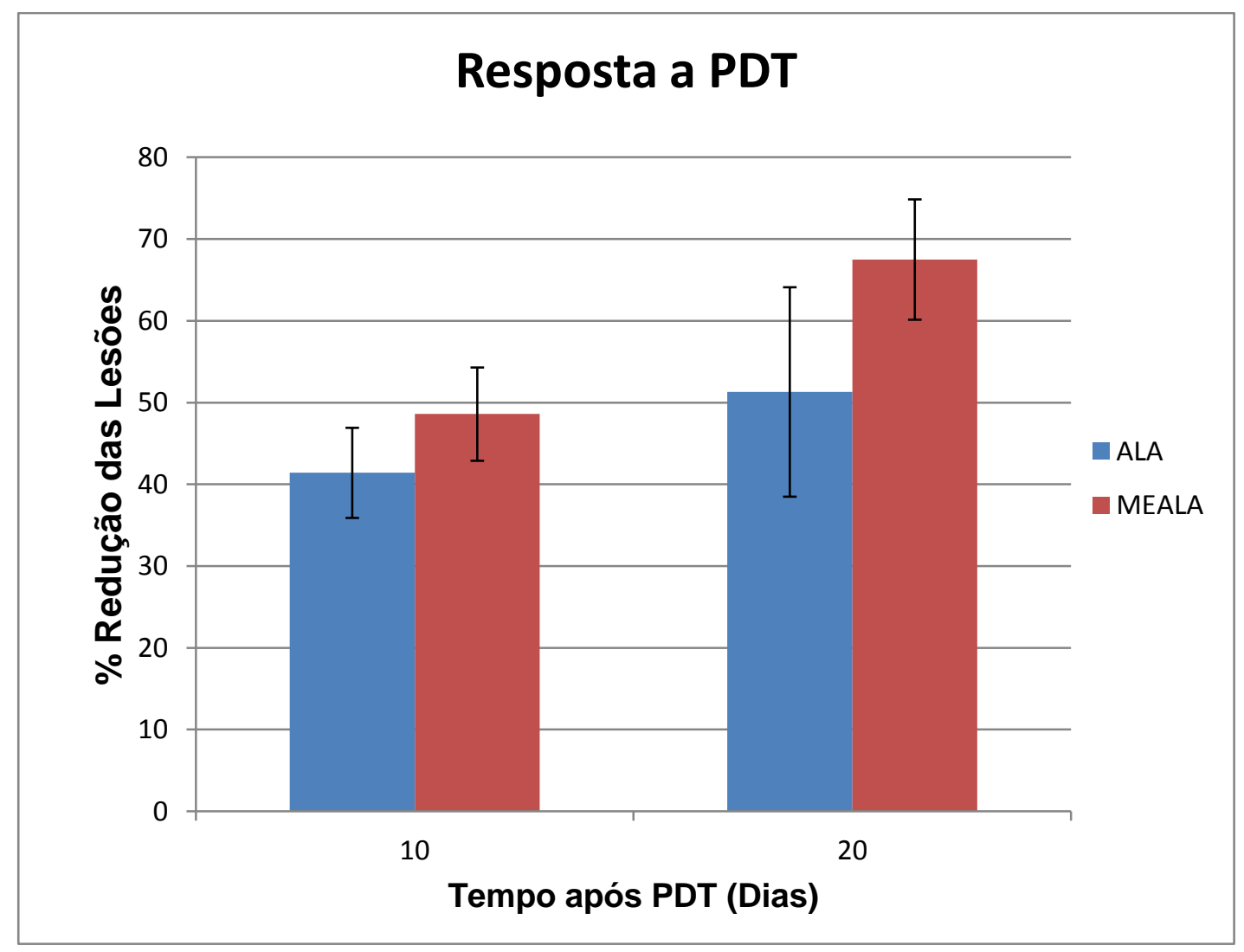

FIGURA 26: Resposta à $P D T$ representada pelo percentual de redução de área de lesão nos tempos de 10 e 20 dias após o tratamento com os fotossensibilizadores ALA e MEALA. As barras representam o erro padrão.

A FIGURA 26 nos revela uma tendência de maior redução nas lesões do grupo tratado com o fotossensibilizador MEALA tanto em 10 como em 20 dias após o tratamento. A maior barra de erro verificada no grupo ALA 20 dias ocorreu devido à morte de mais um animal deste grupo no intervalo de tempo, o que reduziu o número total de lesões avaliadas neste grupo e pode ter influenciado o resultado deste grupo. 
Para a análise estatística dos resultados, a normalidade dos dados foi avaliada com o teste de Shapiro-Wilk, e a homogeneidade ente as variâncias com o teste de Bartlett's, ambos com 5\% de significância. Uma vez que os dados se encontraram dentro dessas condições, eles foram analisados estatisticamente por análise de variância (ANOVA), com $5 \%$ de significância, sendo a comparação entre os grupos realizadas com o teste de Tukey-Kramer, também considerando $5 \%$ de significância.

Apesar do MEALA nos dois períodos avaliados apresentar uma média de percentual de redução da lesão maior que o ALA, os tratamentos não apresentam diferenças significativa entre si em nenhum dos períodos.

As FIGURAS 27 e 28 representam o perfil de redução de área de cada fotossensibilizador ALA e MEALA respectivamente. 

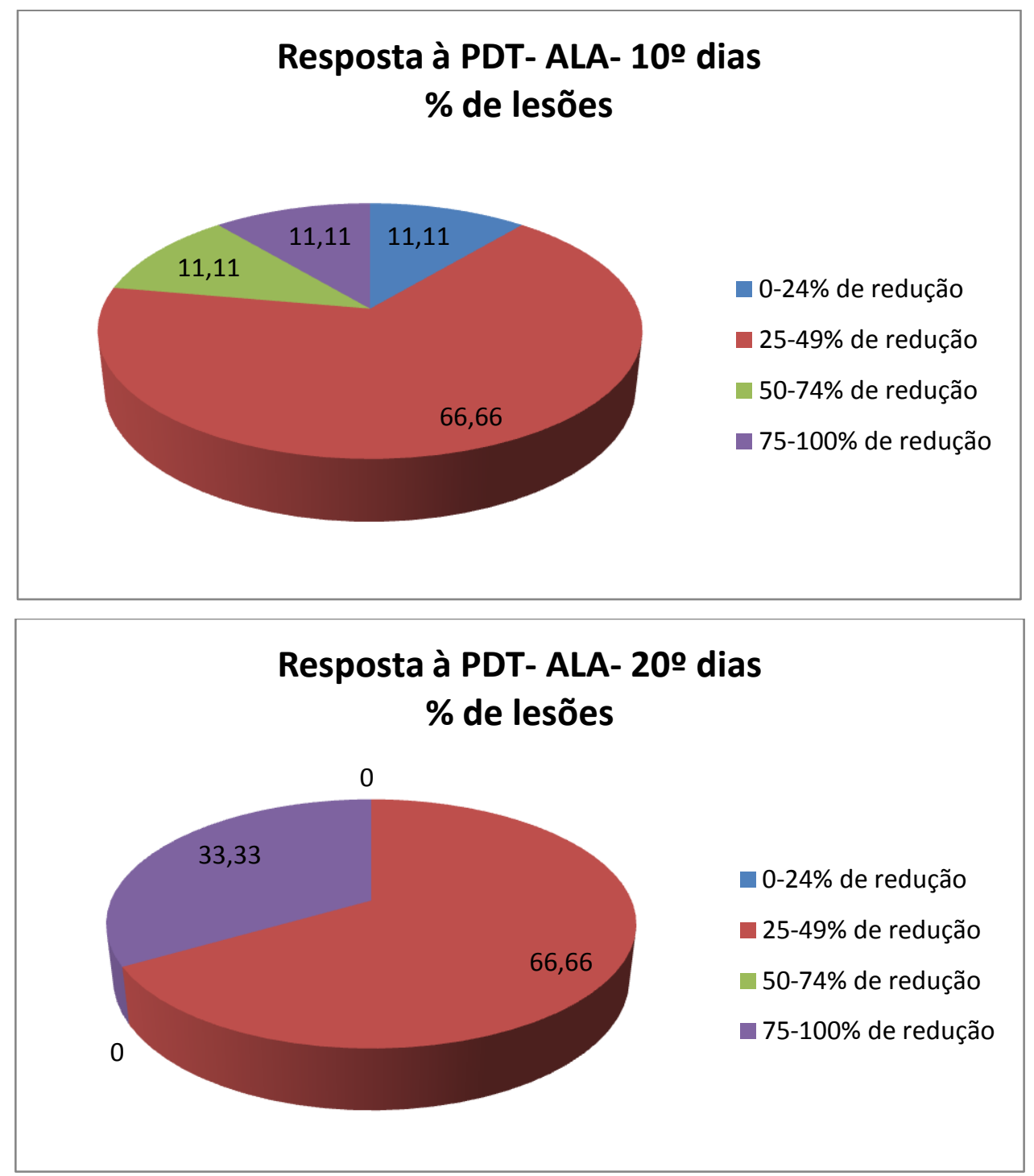

FIGURA 27: Resposta clínica em \% de redução de área das lesões dos grupos que foram submetidos ao tratamento de terapia fotodinâmica com o fotossensibilizadores ALA.

A FIGURA 27 demonstra que os animais tratados com o ALA, tiveram $66 \%$ das lesões reduzindo sua área entre 25 a $49 \%$ nos 10 dias após a PDT, este percentual se manteve 20 dias após a PDT havendo um aumento na quantidade de lesões com redução entre 75 a 100\% (33\%). 

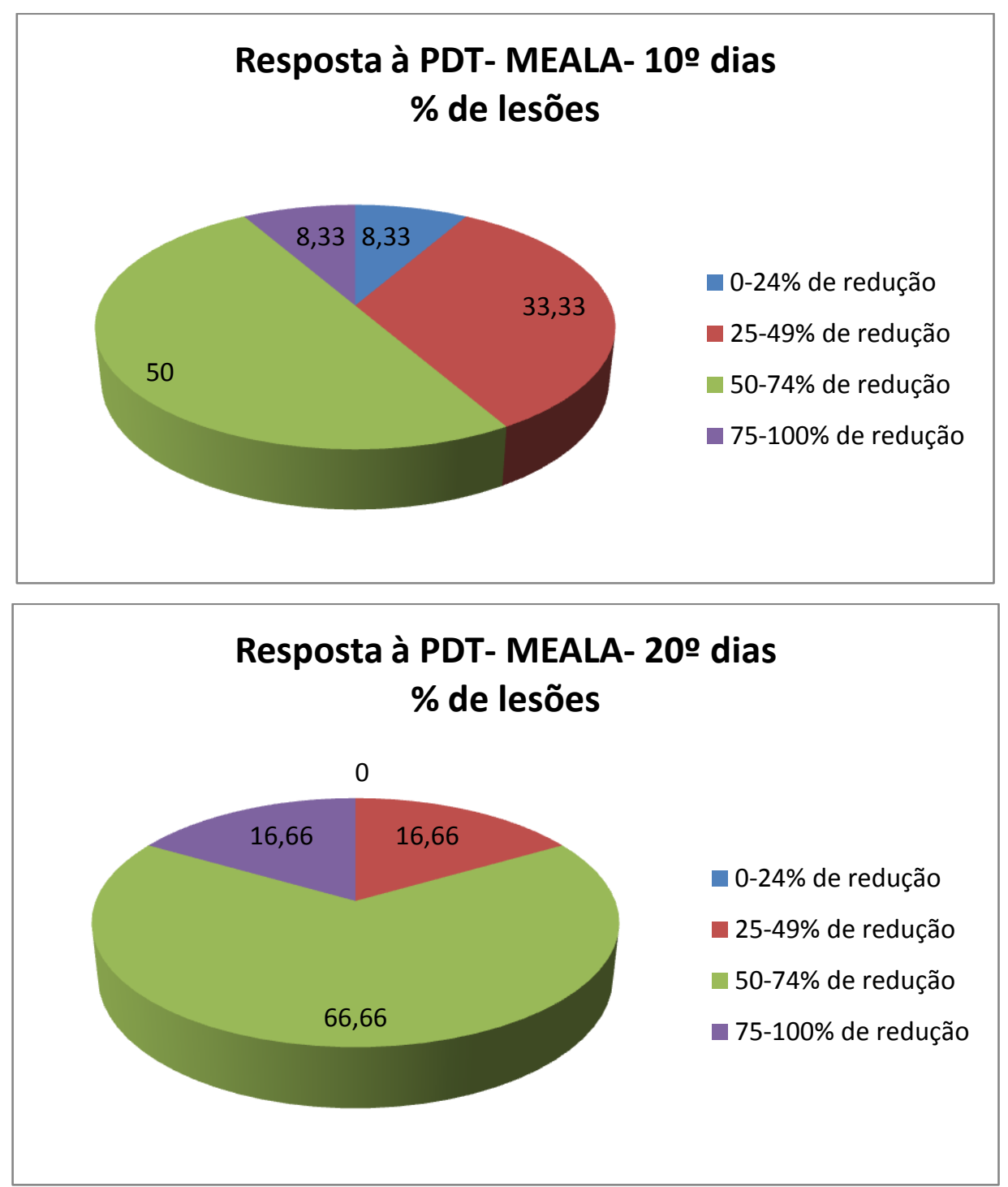

FIGURA 28: Resposta clínica em \% de redução de área das lesões dos grupos que foram submetidos ao tratamento de terapia fotodinâmica com o fotossensibilizadores MEALA.

A FIGURA 28 evidencia uma redução de área entre 50 à $74 \%$ na metade das lesões que utilizaram MEALA após 10 dias. Após 20 dias o número de lesões entre 50 a $74 \%$ e entre 75 à 100\% de redução aumentam com apenas uma sessão de terapia fotodinâmica.

No período de 0 à 20 dias, o percentual de lesões com redução de área maior que $50 \%$, foi de $33 \%$ na PDT com ALA e $83 \%$ para o MEALA, reforçando que este, apesar de sua menor concentração, foi mais eficiente que o ALA na PDT. 
Este resultado revela a terapia fotodinâmica como promissora para tratamento de lesões neoplásicas cutâneas de caráter maligno como é o caso do carcinoma espinocelular deste trabalho.

\subsection{Avaliação Histopatológica}

Considerando a avaliação histopatológica o padrão ouro para a análise do tratamento, foi realizada uma análise do perfil histológico da pele sadia e neoplásica e uma descrição de ambos tecidos estão ilustrados na FIGURA 29.

Os cortes histológicos de peles sadias evidenciam epiderme com 3 a 4 camadas de células, uma camada de queratina discreta. A derme é composta de tecido conjuntivo denso, folículos pilosos evidentes e uma hipoderme organizada características presente na FIG. 29 E.

Nos cortes histológicos de lesões neoplásicas nota-se uma proliferação intensa de queratinócitos de padrão exofítico originando cordões sólidos. A camada basal do epitélio exibe uma displasia moderada, camada de queratina espessa e hipercromatismo. O estroma apresenta um tecido conjuntivo denso bem celularizado. 

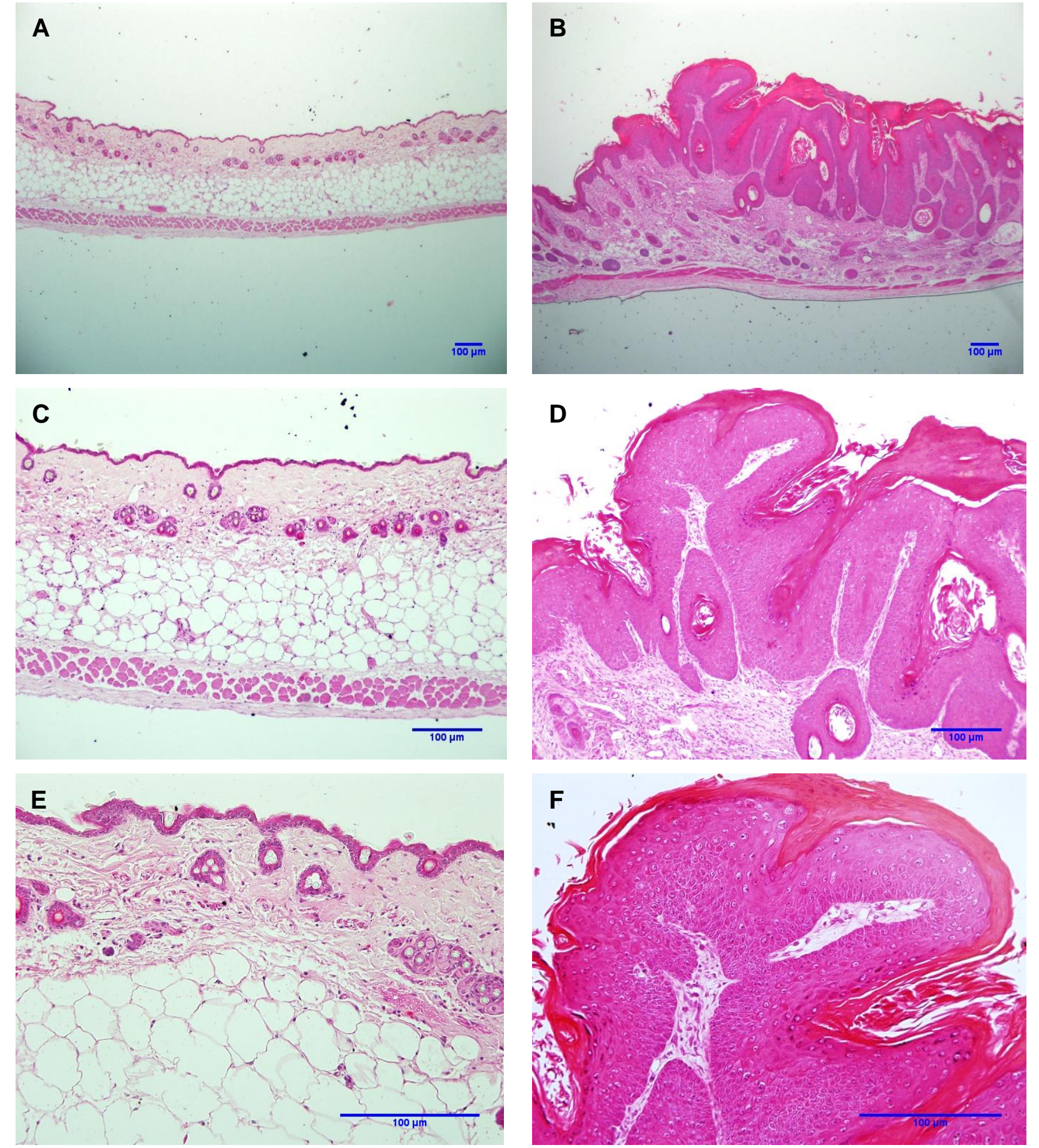

FIGURA 29: Microscopia de luz de cortes histológicos representativos. (A), (C) e (E) Pele sadia do grupo controle (objetivas de 4X,10X e 20X, respectivamente. (B), (D) e (F) Lesões neoplásicas no dia 0 (objetivas de 4X, 10X e 20X) respectivamente. 
Uma análise histopatológica das lesões dos grupos submetidos à $P D T$ foi realizada e está representada na FIGURA 30.
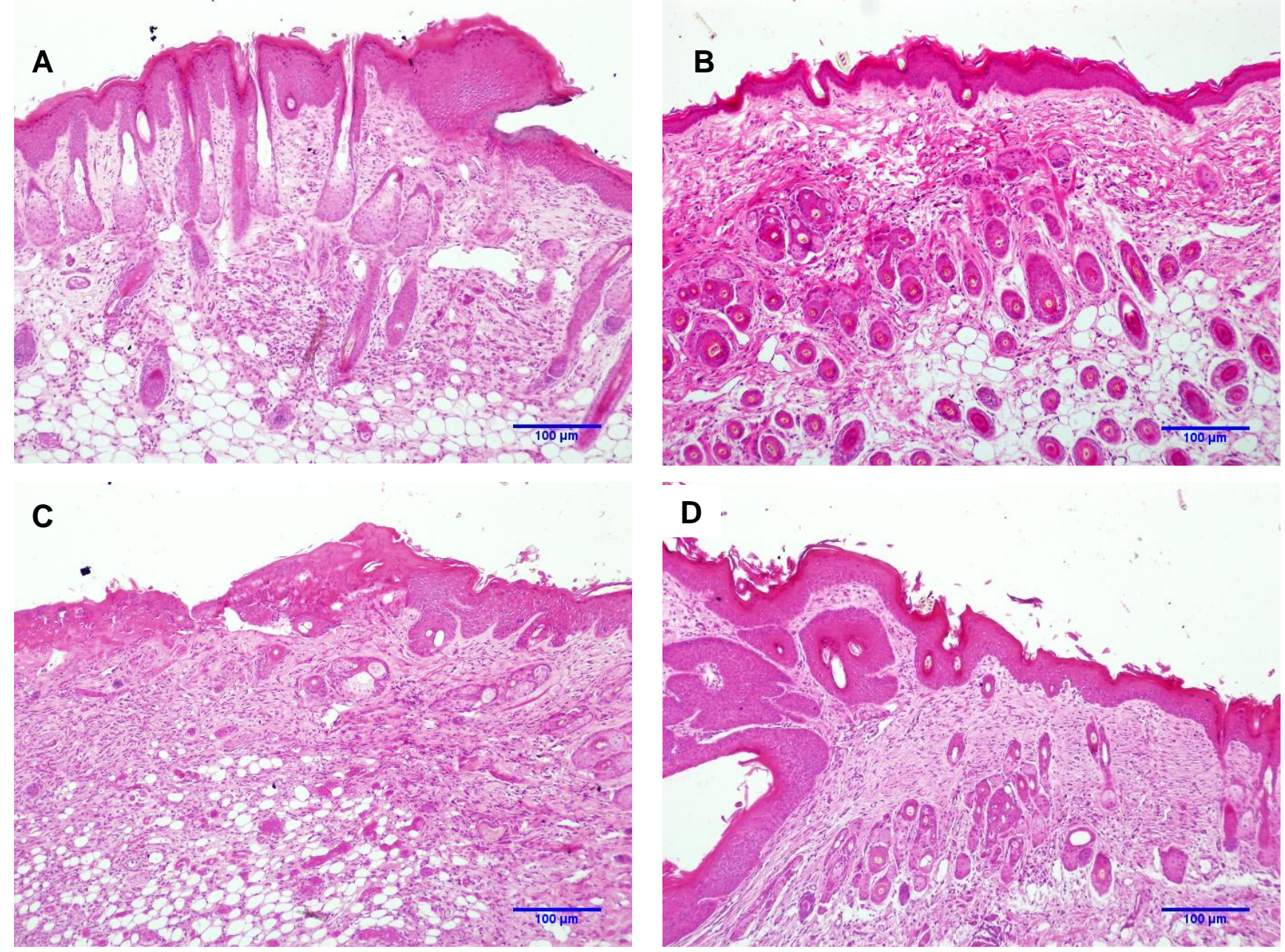

FIGURA 30: Microscopia de luz de cortes histológicos representativos. (A) e (B) Lesões Neoplásicas após a PDT com ALA -10 dias e 20 dias, respectivamente (objetivas de 10X). (C) e (D). Lesões Neoplásicas após a PDT com MEALA -10 dias e 20 dias, respectivamente (objetivas de 10X).

Nos grupos submetidos a $P D T$, os cortes histológicos da lesão (FIGURA 30) demonstram a presença de ulceração com necrose superficial, hiperplasia do epitélio, um estroma com tecido conjuntivo denso substituindo a proliferação papilomatosa de potencial maligno e com ausência de padrão exofítico e/ou infiltrativo. Baseando-se na avaliação clínica é possível relatar uma redução 
significativa das lesões neoplásicas nos grupos tratados com ambos fotossensibilizadores.

A comparação histopatológica das respostas entre os grupos PDT ALA (G6) e PDT MEALA (G7) com 10 e 20 dias indica que a PDT com MEALA foi mais eficiente.

As avaliações clínica e histopatológica indicam que a $P D T$ realizada no momento de máxima incorporação de protoporfirina IX foram eficazes no tratamento deste tipo de neoplasias de pele.

\subsection{Tomografias por Coerência Óptica}

A partir da análise de sinal de OCT foi obtido o coeficiente de atenuação óptico médio relativo para cada grupo do estudo. Os dados foram correlacionados com a pele sadia, ou seja, quanto mais próximo do coeficiente de atenuação da pele sadia melhor foi o efeito da PDT. Para a utilização desta técnica como diagnóstico, dois fatores podem ser levados em conta: o coeficiente de atenuação óptico e a imagem captada. Com relação ao primeiro fator, quanto maior for à relação entre os coeficientes de atenuação da pele sadia e da neoplasia, mais alterações este tecido possui. Com o auxilio da imagem gerada e uma avaliação clínica também é possível identificar o tecido neoplásico. A FIGURA 31 apresenta imagens representativas de OCT da pele sadia e do tecido neoplásico. 

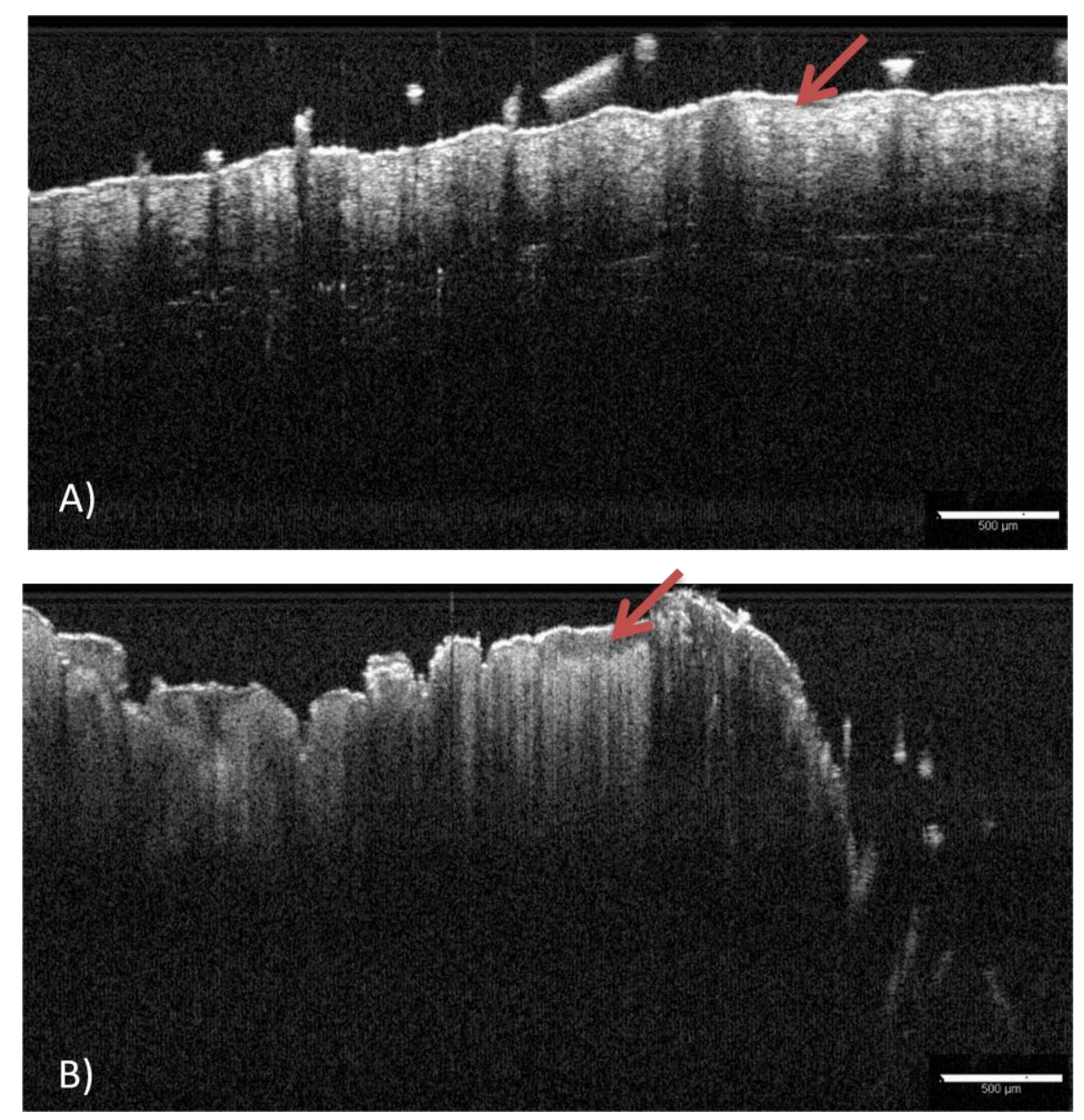

FIGURA 31: Imagens de OCT, (A) Pele Sadia e (B) Tecido Neoplásico.

De acordo com as imagens de OCT, foi possível visualizar, indicado pela seta vermelha, o epitélio sadio com fina camada de células e o neoplásico muito mais espesso demonstrando a hiperplasia característica do tecido.

Para avaliarmos o coeficiente de atenuação relativo dos grupos, foi realizada a razão com o valor médio do grupo controle.

Consideramos três faixas de profundidade para análise a fim de verificar a especificidade de análise e a interferência da luz refletida ao mudar do meio propagador ar para a pele. Os valores de coeficientes de atenuação relativo de cada grupo G1 (controle), G4 e G5 (neoplasia), G6 e G7 (neoplasia PDT 10 e 20 dias) foram comparados em função da profundidade 0 a $400 \mu \mathrm{m}, 20$ a $400 \mu \mathrm{m}$ e 10 a $300 \mu \mathrm{m}$, representados nas FIGURAS $(32,33,34)$. 


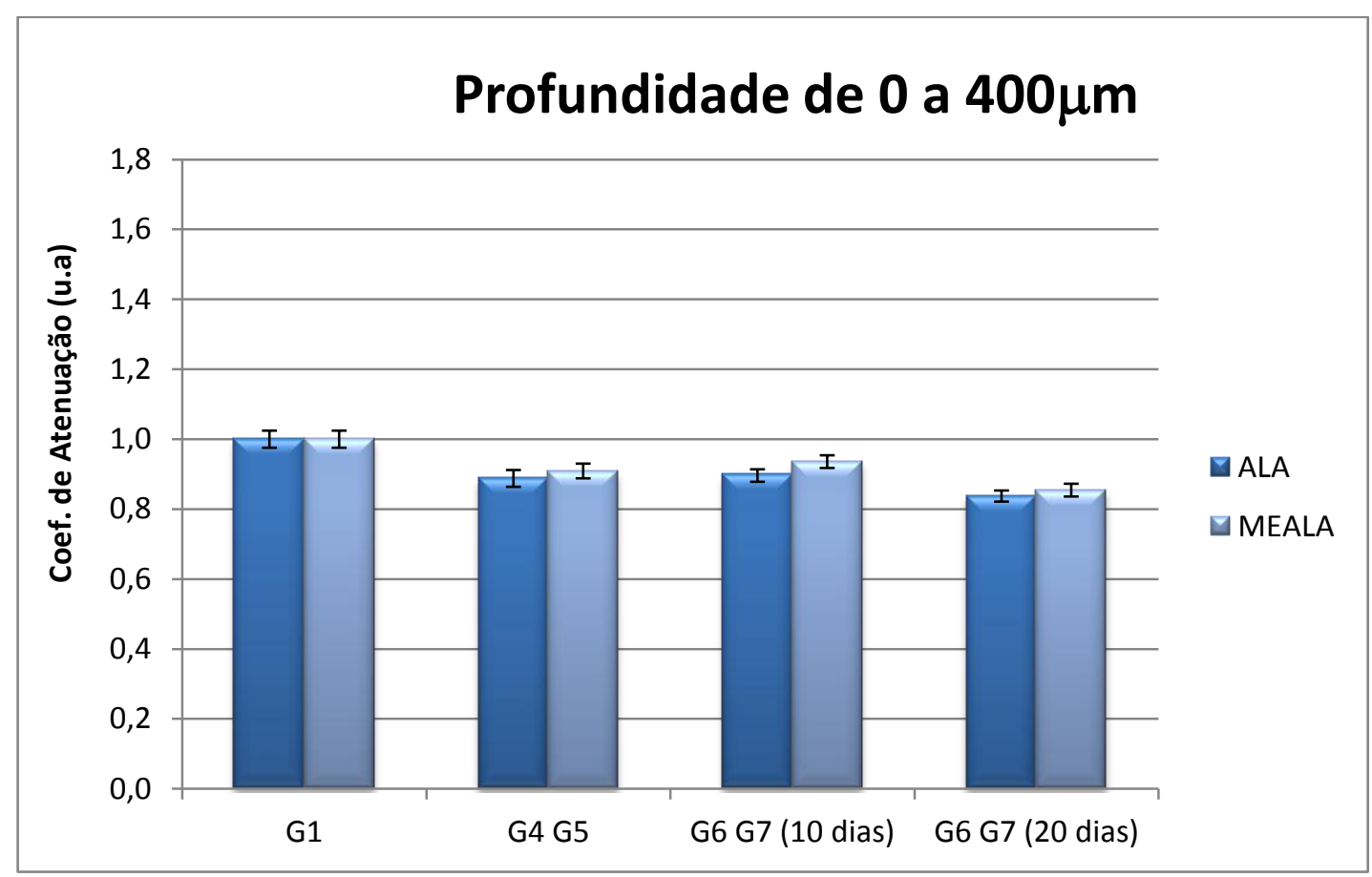

FIGURA 32: Coeficiente de atenuação óptico relativo, dos grupos G1(controle), G4 e G5(neoplasia), G6 e G7 (neoplasia10 e 20 dias) calculado para profundidade de 0 a $400 \mu \mathrm{m}$. As barras correspondem ao erro padrão.

A FIGURA 32 indica que a técnica exige uma precisa delimitação da profundidade de interesse, pois como já foi mencionado o perfil de decaimento utilizado para a análise é obtida pela média aritmética de todas as colunas da imagem de OCT na região de interesse, fato ilustrado na FIGURA 17.

O carcinoma espinocelular é caracterizado por alterações principalmente no epitélio, ou seja, na superfície.

A profundidade de 0 a $400 \mu \mathrm{m}$ abrange a luz retroespalhada de todas as camadas da pele: epiderme, derme hipoderme e na pele sadia até a camada muscular e inclusive a luz refletida ao mudar de meio, indicando que os dados refletem um efeito de "bulk", isto é, incluem informações a respeito do tecido neoplásico, mas principalmente contribuições de regiões mais profundas com características mais próximas à normalidade. Portando não foi possível obter a diferenciação entre os grupos e a resposta ao tratamento para esta faixa. 


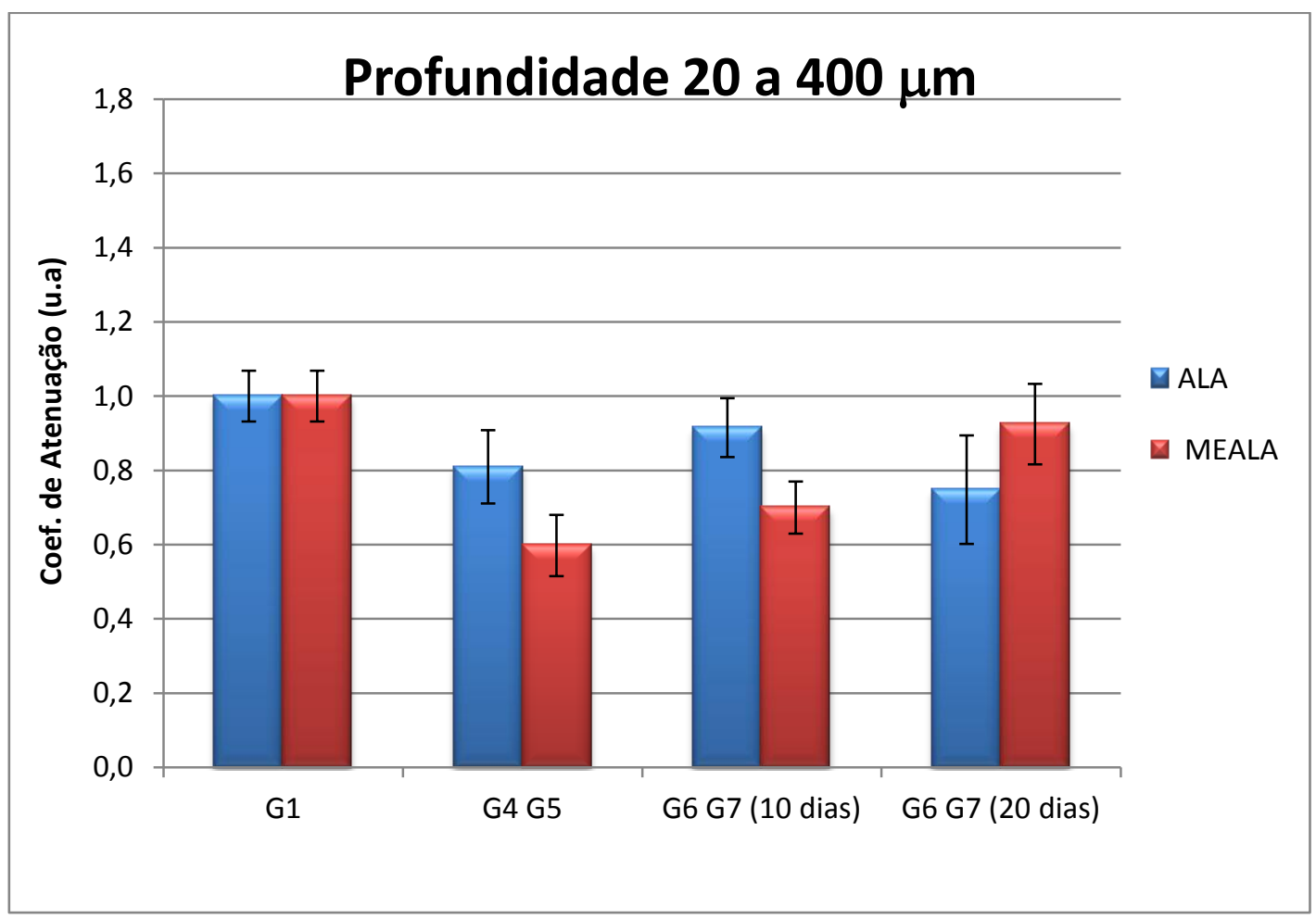

FIGURA 33: Coeficiente de atenuação óptico relativo, dos grupos G1(controle), G4 e G5 (neoplasia), G6 e G7 (neoplasia10 e 20 dias) calculada para profundidade de 20 á $400 \mu \mathrm{m}$. As barras correspondem ao erro padrão.

Novamente, a normalidade dos dados foi avaliada com o teste de ShapiroWilk, e a homogeneidade entre as variâncias com o teste de Bartlett's, ambos com $5 \%$ de significância. Como os dados se encontravam dentro das condições de normalidade, eles foram analisados estatisticamente por análise de variância (ANOVA), com 5\% de significância, sendo a comparação entre os grupos realizada com o teste de Tukey-Kramer, também considerando 5\% de significância, entretanto não foi encontrada diferença estatística significativa entre os grupos.

A profundidade de 20 a $400 \mu \mathrm{m}$ representada na (FIGURA 33) permitiu a diferenciação do tecido sadio (G1) do neoplásico (G4 e G5), porém a resposta ao tratamento não foi claramente evidenciada. Este fato é relacionado a neoplasia ser no epitélio ou seja na primeira camada da pele, e esta faixa de avaliação não considerar os mais proveniente micrometros da região de interesse. 
Com base nos resultados da FIGURA 32 e 33 e pela avaliação da espessura média do epitélio do grupo sadio e neoplásico uma análise dos dados na profundidade de 10 á $300 \mu \mathrm{m}$ (FIGURA 33), foi determinada, pois nesta faixa, primeiramente ignoramos a interferência da luz refletida e do retroespalhamento da camada de queratina que envolve a pele e a lesão neoplásica.

Já a limitação em $300 \mu \mathrm{m}$ faz com que a análise não considere sinal de regiões mais profundas da pele como hipoderme, que praticamente não é alterada pela neoplasia, logo não interfere na média do perfil de decaimento da intensidade de luz retroespalhada, tornando a análise deste tipo de tecidos e a resposta ao tratamento mais especifica por este método.

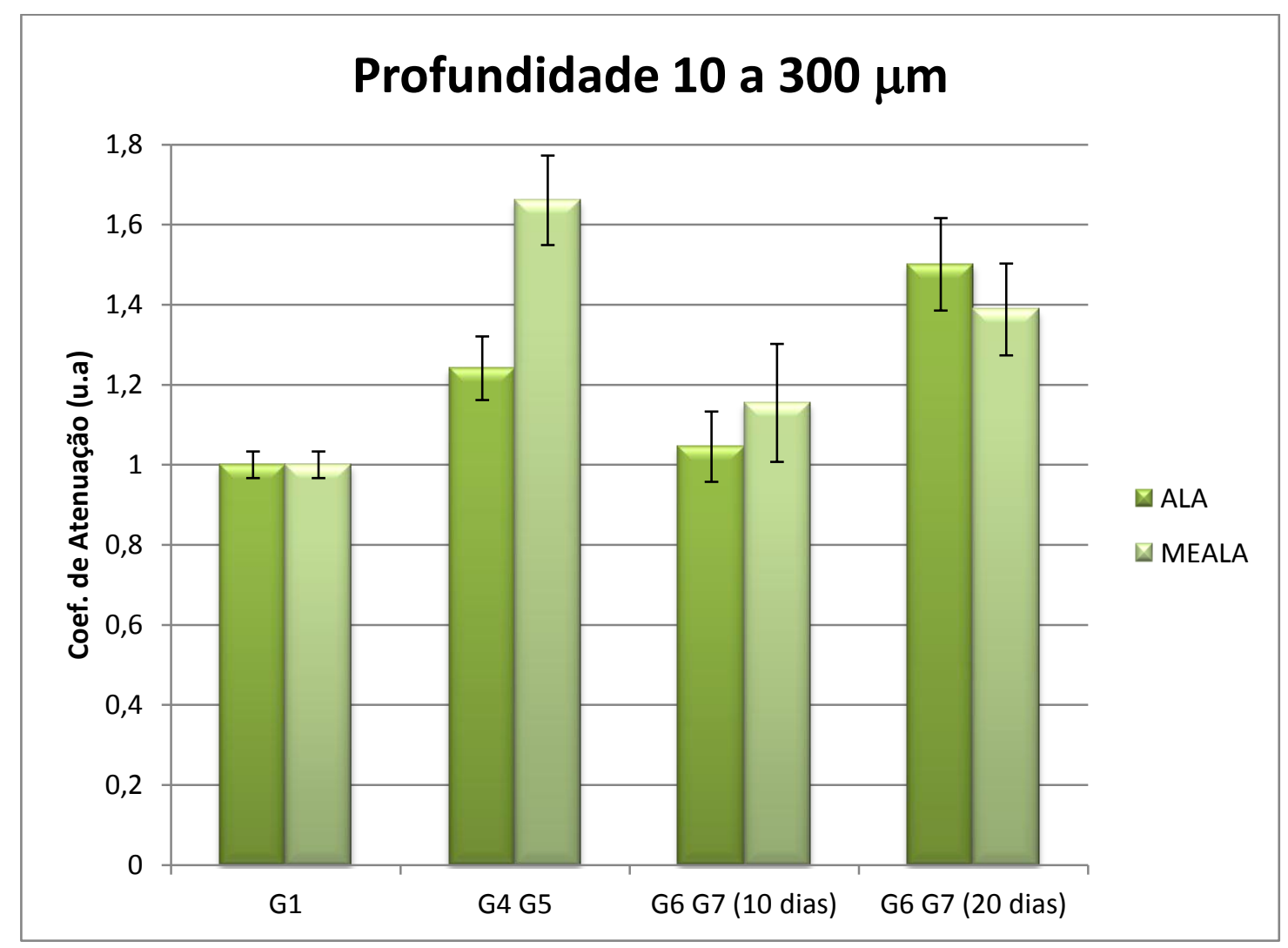

FIGURA 34: Coeficiente de Atenuação óptico relativo, dos grupos G1 (controle), G4 e G5 (neoplasia), G6 e G7 (neoplasia 10 e 20 dias) calculado para profundidade de 10 á $300 \mu \mathrm{m}$.

Como anteriormente os dados se encontravam dentro das condições de normalidade, eles foram analisados estatisticamente por análise de variância 
(ANOVA), com $5 \%$ de significância, sendo a comparação entre os grupos foi realizada com o teste de Tukey-Kramer, também considerando $5 \%$ de significância. Nesta análise foi observada diferença estatística entre os grupos, sendo os valores de $p$ encontrados apresentados na Tabela 7.

Os resultados mostrados na FIGURA 34 comprovam que esta região de análise nos permite verificar uma maior diferenciação tanto do tecido sadio e neoplásico quanto da resposta ao tratamento em 10 e 20 dias. Com esta delimitação conseguimos analisar a região de interesse de forma mais peculiar.

O menor coeficiente de atenuação óptico relativo foi do grupo G1 (Controle) e o maior foi dos grupos G4 e G5 (neoplasia). Os coeficientes de atenuação dos grupos tratados com $P D T$ tendem a se aproximar dos valores obtidos para a pele sadia (G1) evidenciando a resposta ao tratamento. A diferenciação do grupo controle com o grupo neoplasia e do grupo neoplásico com o grupo PDT 10 dias somente foi estatisticamente significante no grupo que utilizou o FFS MEALA.

$\mathrm{O}$ que utilizou o ALA apresentou diferença estatisticamente significante entre os grupos controle, PDT 10 dias e PDT 20 dias, mas ocorreu um aumento do coeficiente de atenuação em relação a pele sadia em 10 e 20 dias.

A redução do coeficiente de atenuação relativo do grupo ALA (G6) após 10 dias da $P D T$ pode estar relacionada à maior intensidade de fluorescência verificada por espectroscopia deste grupo.

O grupo MEALA (G7) possui um coeficiente de atenuação menor em 10 dias após $P D T$, aumentando aos 20 dias, entretanto não há diferença significativa. Este fato também foi observado no grupo ALA (G6), porém com diferença significativa. Isto se deve possivelmente a uma resposta de defesa da própria neoplasia e ao tratamento ter sido realizado com apenas uma sessão de PDT.

TABELA 7: Valores de $p$ encontrados com o Teste de TUKEY na comparação entre o coeficiente de atenuação dos grupos G1(controle), G4 e G5 (neoplasia), G6 e G7 (neoplasia 10 e 20 dias) em profundidade de 10 á $300 \mu \mathrm{m}$. 


\begin{tabular}{c|c}
\hline Teste deTukey & Valor de $\boldsymbol{p}$ \\
Controle vs & \\
\hline Neoplasia PDT MEALA & $\mathrm{ns}$ \\
Controle vs & $0,01-0,05$ \\
Neoplasia PDT MEALA 20d & \\
Neoplasia MEALA vs & $0,001-0,01$ \\
Neoplasia PDTMEALA & \\
Neoplasia MEALA vs & $\mathrm{ns}$ \\
Neoplasia PDT MEALA 20d & \\
Neoplasia PDT MEALA vs & $\mathrm{ns}$ \\
Neoplasia PDT MEALA 20d & \\
Controle vs Neoplasia ALA & $\mathrm{ns}$ \\
Controle vs & $0,01-0,05$ \\
Neoplasia PDT ALA & \\
Controle vs & $<0,001$ \\
Neoplasia PDT ALA 20d & \\
Neoplasia ALA vs & $\mathrm{ns}$ \\
Neoplasia PDT ALA & \\
Neoplasia ALA vs & $<0,001$ \\
Neoplasia PDT ALA 20d & \\
Neoplasia PDT ALA vs & \\
\hline Neoplasia PDT ALA 20d & \\
\hline
\end{tabular}




\section{Discussão}

O modelo de carcinogênese química ${ }^{82}$ realizado para a indução e promoção do tumor nos animais de estudo, se mostrou eficaz no desenvolvimento de carcinoma espinocelular (FIGURA 12) O modelo de carcinogênese cutânea em camundongos oferece uma boa oportunidade de estudar vários fatores relacionados ao câncer de pele desde prevenção, resposta e otimização de tratamento como foi o nosso caso. As fases de iniciação e promoção ocorrem com aplicações tópicas de carcinógenos como DMBA que induz a inflamação e o estresse oxidativo relacionado com o dano ao DNA como mutações nos genes p53 e ras que podem desempenhar um papel na iniciação e progressão de proliferação celular ${ }^{23}$, provocando angiogênese e ocasionando alterações na pele, como papilomas. A desvantagem deste modelo é o longo tempo de indução e a grande perda ocasionada pelo estado debilitado dos animais em 31 semanas de experimento, fazendo com que reduzisse o número de amostras ( $n_{\text {inicial }}=50$ e $\left.n_{\text {final }}=25\right)$ e a significância estatística das análises, baixa.

O carcinoma espinocelular é caracterizado por tecido epitelial hiperplásico e com intensa proliferação, acompanhado de células inflamatórias ${ }^{27}$. Com a progressão do tumor aumenta-se o número de camada do epitélio apresentando uma displasia severa e elevada queratinização das camadas superiores, resultado mostrado na FIGURA 29.

Este estudo otimizou o momento ideal para iniciar o tratamento de PDT em carcinomas espinocelular induzidos em camundongos por meio de espectroscopia de fluorescência, técnica bem estabelecida e utilizada por vários grupos de pesquisa que analisam a intensidade de fluorescência da PPIX ${ }^{34,48,53,54,59}$.

O arranjo experimental utilizado consta de um laser para excitação da fluorescência, fibra óptica e espectrômetro, entretanto a grande diferença do nosso trabalho é a normalização nos dados antes da análise. Assim, pequenas variações da inclinação da fibra ou a distância da fibra à lesão que influencia a luminosidade ambiente, não contribuíram para o resultado deste trabalho. Este cuidado raramente 
tem sido tomado em trabalhos similares na literatura ${ }^{34,56,60,61}$. A importância desta normalização foi comprovada por Drakaki, et $a \beta^{\beta 1}$ onde somente após uma normalização dos dados, dois pico de fluorescência foram constatados no espectro do tecido tumoral, permitindo diferenciá-lo do tecido normal. Portanto, reforça-se aqui a importância e imprescindibilidade da normalização utilizada em nosso trabalho.

Os resultados da monitoração da concentração das moléculas de PPIX revelaram que a máxima intensidade de fluorescência ocorre em momentos diferentes para os grupos controles e grupos neoplásicos, assim como diferentes intensidades para os fotossensibilizadores ALA e MEALA como mostram as FIGURAS: 18, 19, 20 e 21. Quanto maior a concentração da protoporfirina IX, mais espécies reativas de oxigênio presentes no tecido poderão ser formadas e consequentemente maior o potencial de morte de células. $O$ fato da máxima intensidade de fluorescência no tecido controle ter sido diferente do tecido neoplásico garante à terapia fotodinâmica a vantagem da seletividade e menor efeito ao tecido sadio adjacente.

A maior intensidade de fluorescência encontrada no grupo neoplásico discorda dos achados de Panjehpour, et $a^{\beta 4}$, onde o tecido normal obteve maior intensidade de emissão e concorda com Brancaleon, et al, no qual a intensidade de emissão do tumor foi maior e atribuída a hiperatividade e proliferação epidermal do tumor, embora ambos os trabalhos não envolvessem a aplicação de fotossensibilizadores.

O grupo no qual foi utilizado o ALA como fotossensibilizador apresentou uma intensidade maior de fluorescência (FIGURA 22), resultado também encontrado pelo grupo de Lesar, et $a l^{90}$, entretanto houve divergência quanto ao tempo de máxima intensidade pois nosso estudo relatou o pico após $5 \mathrm{~h}$ e $5 \mathrm{~h} 30 \mathrm{~min}$ da aplicação do ALA e MEALA respectivamente. Lesar et a ${ }^{88,90}$ relatou a máxima fluorescência em 7 e 24 horas, para ambos FFSs em pele humana. Nosso estudo não acompanhou a fluorescência por período tão longo por considerar que em $24 \mathrm{hs}$ poderia ocorrer à degradação da PPIX acumulada, assim como por ser um período considerado inviável para tratamentos clínicos, sobretudo em ambiente ambulatorial. 
O resultado da baixa intensidade de fluorescência constada do grupo MEALA (FIGURA 23) pode ter ocorrido devido a menor concentração utilizada e este FFS ter maior penetração na lesão quando comparado ao $\operatorname{ALA}^{25}$. Como o comprimento de onda do laser de excitação utilizado possui alta absorção pela PPIX na pele e, portanto baixa penetração no tecido de acordo com Nadeau, et $a{ }^{48}$, não atingiu a PPIX induzida pelo MEALA em maiores profundidades.

Após a otimização do tempo de acumulo da PPIX foi realizada a PDT 5h e 5h30min após a aplicação do ALA e MEALA, respectivamente. A avaliação clínica (FIGURAS 25 e 26) e histopatológica (FIGURA 30) verificou que houve a resposta ao tratamento no tempo ideal e a eficácia de cada fotossensibilizador. Verificamos que 0 MEALA foi o FFS mais eficaz. Clinicamente este grupo apresentou uma redução de área de lesão maior, sendo que mais da metade das lesões obtiveram redução entre 50 a 74\%. De acordo com a avaliação histopatológica este FFS promoveu uma redução da hiperplasia e atípia celular.

Os resultados comprovam que a realização da $P D T$ com os fotossensibilizadores ALA e MEALA, no momento de maior intensidade de fluorescência promove resultados promissores para o tratamento do carcinoma espinocelular de pele, porém mais estudos avaliando múltiplas sessões da terapia são recomendados, para aumentar as possibilidades de cura.

Uma abordagem original deste trabalho consistiu em avaliar a resposta do tratamento por meio do $O C T$, técnica óptica não invasiva que vem sendo empregada como uma nova técnica de diagnóstico ${ }^{95}$. Na técnica de OCT características lineares como espalhamento, absorção, birrefringência, e índice de reflexão são mensuradas para produção de imagens com resolução micrométricas ${ }^{96}$. Na literatura geralmente as imagens de OCT são comparadas com a histologia. Nosso estudo avaliou a diferença do coeficiente de atenuação dos grupos: 1, 4, 5, 6 e 7, propriedade óptica que não apresenta relatos na literatura quanto ao tecido tumoral.

A medição localizada do coeficiente de atenuação óptico pode fornecer importantes informações adicionais à imagem de OCT, podendo aumentar o potencial clínico do uso de $O C T$, o que permite a discriminação quantitativa entre diferentes tipos de tecidos. 
O coeficiente de atenuação pode ser medido a partir de um software desenvolvido no Centro de Lasers e Aplicações - IPEN/CNEN que permite o ajuste do sinal de espalhamento na região de interesse de uma imagem OCT. Dois modelos estão disponíveis na literatura, O modelo de espalhamento único, utilizado no software de nosso estudo, é o modelo mais utilizado e pressupõe que apenas fótons que tenham sido retroespalhados uma única vez contribuam para o sinal de OCT. O modelo de espalhamento múltiplo que foi introduzido por Thrane, et $a^{\beta 7}$, tem sido usado recentemente para extrair propriedades ópticas de lesões ateroscleróticas e da pele humana ${ }^{98}$.

O coeficiente de atenuação óptico relativo do tecido neoplásico foi maior que da pele sadia (FIGURA 34). Isto ocorreu devido ao maior número de células, ou seja, a hiperplasia presente no tumor, que aumenta o espalhamento da luz. Outro fato importante é a desorganização presente no tecido neoplásico, que também aumenta o número de interfaces e consequentemente, o coeficiente de atenuação. Após 10 dias do tratamento de $P D T$, verificamos uma redução do coeficiente de atenuação elucidando a resposta ao tratamento, ou seja, um epitélio menos denso facilitando a penetração da luz, similar a pele sadia. Ressalta-se que é essencial a correta escolha da faixa de profundidade de análise do sinal de OCT, neste estudo baseada nas características da imagem histológica.

Como já mencionado, no melhor de nosso conhecimento, são inexistentes estudos que avaliem o coeficiente de atenuação para diagnóstico ou para avaliação da eficácia do tratamento do câncer, como verificado em nosso estudo. Sendo assim, não há relatos que permitam uma comparação direta dos valores do coeficiente de atenuação óptico relacionado com a hiperplasia local.

Assim, apenas foi possível realizar uma comparação qualitativa de nossos resultados para coeficiente de atenuação óptico com os resultados de Korde, et a ${ }^{99}$ que verificaram a atenuação do sinal de $O C T$ da pele exposta ao sol e de lesões pré cancerígena $(A Q)$ cujo sinal apresentou uma maior atenuação para as lesões de queratose actínica comparada com a pele sadia. A maior atenuação do sinal de OCT foi justificada pelo retroespalhamento causado pela hiperqueratose e células displásicas presente nas lesões, como também ocorreu em nosso estudo. 
Apesar da análise por coeficiente de atenuação óptico ser inovadora e necessitar de uma delimitação da região de interesse, esta propriedade óptica pode nos fornecer informações relevantes a respeito dos tecidos avaliados, mostrando-se uma ferramenta promissora para diagnóstico de lesão de pele. 


\section{Conclusões}

Os resultados deste estudo indicam que o melhor momento para iniciar a $P D T$ é aproximadamente 300 e 330 minutos após a aplicação dos fotossensibilizadores ALA e MEALA respectivamente.

O MEALA mesmo em concentração inferior ao ALA foi 0 fotossensibilizador mais eficiente para terapia fotodinâmica no tratamento de carcinoma espinocelular induzido em pele, verificados pelas técnicas de OCT, avaliação clínica e avaliação histopatológica.

A técnica de OCT foi capaz de diferenciar os coeficientes de atenuação ópticos na profundidade de 10 a $300 \mu \mathrm{m}$. Os grupos com neoplasia obtiveram os maiores valores de coeficiente do que os do grupo controle. Os grupos tratados com $P D T$ apresentaram valores de coeficiente de atenuação que se aproximam dos valores obtidos para a pele sadia, evidenciando a resposta ao tratamento. 


\section{Anexo}

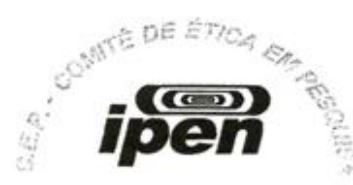

Parecer - Projeto $N^{\circ}$ 71/10 - CEUA-IPEN/SP

Com base nos pareceres apresentados pelos relatores, o protocolo de pesquisa "ESPECTROSCOPIA DE FLUORESCÊNCIA NA MONITORAÇÃO E OTIMIZAÇÃO DA TERAPIA FOTODINÂMICA DE CARCINOMA ESPINOCELULAR IN VIVO" de responsabilidade do pesquisador DENISE MARIA ZEZELL foi considerado APROVADO.

Tendo em vista a legislaçăo vigente, devem ser encaminhados, a este Comitê, relatórios anuais (parciais ou finais, dependendo da duração do projeto) referentes ao andamento da pesquisa. Após o término da pesquisa, uma cópia do trabalho deve ser encaminhada a este CEUA.

Săo Paulo, 21 de dezembro de 2010

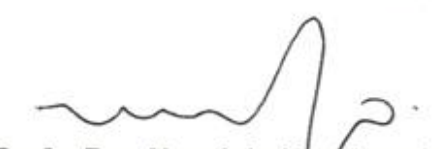

Profa. Dra. Nanci do Nascimento Coordenadora do CEUA-IPEN

IPEN-CNEN/SP
COMITE DE ÉTICA EM PESQUISA ANIMAL

Ctes, 2242 - Cidade Universitária - CEP 05508-000 - Săo Paulo - SP

Telefone: (011) 3133-9698 - Fax (011) 3133-9709

E-mail: nnascime@ipen,br 


\section{Referências}

1 BOYLE, P.; LEVIN, B. World Cancer Report. Lyon: IACC, 2008.

${ }^{2}$ STEWART, B.W.; KLEIHUES, P. World Cancer Report. Lyon: IARC, 2003.

${ }^{3}$ INSTITUTO NACIONAL DO CÂNCER. Estimativa 2012/2013: Incidência de câncer no Brasil. INCA, 2012.

${ }^{4}$ BADIZADEGAN, K. et al. Spectroscopy diagnosis and imaging of invisible precancer. Faraday Discuss, v. 126, p. 265-79, 2009.

${ }^{5}$ WAGNIERES, G.A.; STAR, W.M.; WILSON, B. C.; In vivo fluorescence spectroscopy and imaging for oncological applications. Photochemistry Photobiology, v.68, n.5, p. 603-32, 1998.

${ }^{6}$ PENG, Q.; MOAN, J.; NESLAND, J. M. Correlation of subcellular and intratumoral photosensitizer localization with ultrastructural features after photodynamic therapy. Ultrastructural Pathology, v. 20, p. 109-129, 1996.

${ }^{7}$ LUCROY, M. D., EDWARDS, B. F., MADEWELL, B. R. Veterinary photodynamic therapy. Veterinary Medicine Today: Reference Point, v. 216, n. 1, p. 1745-1751, 2000.

${ }^{8}$ BABILAS, P.; KARRER, S.; SIDOROFF, A.; LANDTHALER, M.; SZEIMIES.

Photodynamic therapy in dermatology - an update. Photodermatology, Photoimmunology\&Photomedicine, v.21. p.142-149, 2005.

${ }^{9}$ ROSA, F. S.; TEDESCO, A. C.; LOPEZ, R. F. V.; PIERRE, M. B. R.; LANGE, N.; MARCHETTI, J. M.; ROTTA, J. C. G.; BENTLEY, M. V. L. B. In vitro skin permeation and retention of 5-aminolevulinic acid ester derivatives for photodynamic therapy. Journal of Controlled Release, n.89, p.261-269, 2003.

${ }^{10}$ ALLISON, R.R.; DOWNIE, G.H.; CUENCA, R.; HU, X.; CHILDS, C.J.H.; SIBATA, C.H. Photosensitizers in clinical PDT. Photodiagnosis and Photodynamic Therapy, n.1, p.27-42, 2004. 
${ }^{11}$ LUNARD, C. N.; TEDESCO, A. C. Synergic photosensitizers: A new trend in photodynamic therapy. Current Organic Chemistry, n.8, p.813-21, 2005.

12 TRIESSCHEIJN, M.; BAAS, P.; SCHELLENS, J. M.; STEWART, F. A. Photodynamic therapy in oncology. Oncologist, n.11, v. 9, p.1034-1044, 2006.

${ }^{13}$ REGULA, J.; MACROBERT, A. J.; GORCHEIN, A.; BUONACCORSI, G. A.; THORPE, S. M.; SPENCER, G. M. et al. Photosensitisation and photodynamic therapy of oesophageal, duodenal, and colorectal tumours using 5 aminolevulinic acid induced protoporphyrin IX - a pilot study. Gut, vol. 36, p.67-75, 1995.

${ }^{14}$ ZHU, T. C.; FINLAY, J. C.The role of photodynamic therapy (PDT) physics. Medical Physical, v, 35, n.7, p. 3127-36, 2008.

15 WINKLER, S.; PROSST, R.L.; HAASE,T.; FLECHTENMACHER, C.H.R.; STERN, J.; GAHLEN, J. First experimental experience in adjuvant intra operative photodynamic therapy (AIOPDT) in S117 sarcoma in mice. Proceedings of SPIE 1605-7422/01, v. 4433, 2001.

${ }^{16}$ IBBOTSON, S. H. An overview of topical photodynamic therapy in dermatology. Photodiagnosis and Photodynamic Therapy, v. 7, p.16-23, 2010.

${ }^{17}$ VOLLET, J. D. Identificação e quantificação de fotossensibilizador em tecido hepático por espectroscopia de fluorescência e sua importância na terapia fotodinâmica. 2007. Dissertação de Mestrado. Instituto de Física de São Carlos.

${ }^{18}$ DERGHAM, A.P.; MURARO, C.C.; RAMOS, E.A.; MESQUITA, L.A.F.; COLLAÇO, L.M. Distribuição dos diagnósticos de lesões pré-neoplásicas e neoplásicas de pele no Hospital Universitário Evangélico de Curitiba. Anais Brasileiros Dermatologia. v. 79, p. 555-559, 2004.

${ }^{19}$ SPENCE, R.A.J.; JONHSTON, P. G. EM ONCOLOGY; JONHSTON, P. G. Cancer chemotherapy and biotherapy; Oxford University Press: Oxford, p. 1-14, 121-132, 2001.

${ }^{20}$ SIMPLICIO, F. I.; MAIONCHI, F.; HIOKA, N. Terapia fotodinâmica: aspectos farmacológicos, aplicações e avanços recentes no desenvolvimento de medicamentos. Química Nova, v. 25, n. 5, p. 801-807, 2002. 
${ }^{21}$ ALMEIDA, V.L., LEITÃO, A., REINA, L.C.B., MONTANARI, C.A., DONNICI, C.L., LOPES, M.T.P. Câncer e agentes antineoplásicos ciclo-celular específicos e ciclo-celular não específicos que interagem com o DNA: uma introdução. Química Nova, v.28, p. 118-129, 2005.

${ }^{22}$ NEVES, R,; LUPI, O.; TALHARI, S. Câncer da Pele. Ed. Medsi, 2001.

${ }^{23}$ DAS, I.; DAS, S.; SAHA, T. Saffron suppresses oxidative stress in DMBA- induced skin carcinoma: A histopathological study. Acta histochemica, v. 112, p.317-327, 2010.

${ }^{24}$ SOUSA, S. R. P.; BORGES, J. C. A.; PAULO, P. A. F.; ARAÚJO, R. F.Uma perspectiva mundial do carcinoma de células escamosas de pele. Revista de Ciências Médicas e Biológicas, v.8, n.1, p.91-97, 2009.

${ }^{25}$ BRAATHEN, L. R.; SZEIMIES, R.M.; BASSET-SEGUIN, N.; BISSONNETTE, R.; FOLEY, P.; PARISER, D. ET AL. Guidelines on the use of photodynamic therapy for nonmelanoma skin cancer: An international consensus. J Am Acad Dermatol, v.56, p.125-43, 2007.

${ }^{26}$ URIBE, A. G.; ZOU, J.; DUVIC, M.; CHO-VEGA, J. H.; PRIETO, V. G.; WANG, L. V. In Vivo Diagnosis of Melanoma and Nonmelanoma Skin Cancer Using Oblique Incidence Diffuse Reflectance Spectrometry. Cancer Research; v.72, p. 2738-2745, 2012.

${ }^{27}$ BELAI, E.B. Modulação da resposta imune durante o desenvolvimento do carcinoma espinocelular. 2011. Dissertação (Mestrado). Faculdade de Odontologia de Bauru. Universidade de São Paulo.

${ }^{28}$ DIEPGEN, T.L., FARTASCH, M., DREXLER AND J. SCHMITT H. Occupational skin cancer induced by ultraviolet radiation and its prevention. British Association of Dermatologists. v. 167, p. 76-84, 2012.

${ }^{29}$ SCHWARTZ, R.A. Skin cancer recognition and management.2nd. Ed. New York: Blackwell Publishing, 2008. 
${ }^{30}$ PATIL, C.A., KIRSHNAMOORTHI, H., ELLIS, D.L., VAN LEEUWEN, T.G., MAHADEVAN-JANSEN, A.A clinical instrument for combined Raman spectroscopyoptical coherence tomography of skin cancers. Lasers in Surgery and Medicine, $v$. 43, p.143-151, 2011.

${ }^{31}$ DRAKAKI, E.; KASELOURIS, E., MAKROPOULOU, M.; SERAFETINIDES, A. A.; TSENGA,A;. STRATIGOS, A. J.; KATSAMBAS, A.D.; ANTONIOU, C. Laser-induced fluorescence and reflectance spectroscopy for the discrimination of basal cell carcinoma from the surrounding normal skin tissue. Skin Pharmacol Physiol, vol.22, p.158-165, 2009.

${ }^{32}$ LEVITT, J. M.; MCLAUGHLIN-DRUBIN M. E., MUNGER, K.; GEORGAKOUDI, IRENE.Automated Biochemical, Morphological, and Organizational Assessment of Precancerous Changes from Endogenous Two-Photon Fluorescence Images. Identifying Pre-Cancers from Endogenous Images, v. 6, p. 1-11, 2011.

${ }^{33}$ BAGNATO, V. S. Novas Técnicas ópticas para a área da saúde. Editora Livraria da Física-São Paulo, 2008.

${ }^{34}$ TYRRELL, J.; CAMPBELL, S.M.; CURNOW, A. The effect of air cooling pain relief on protoporphyrin IX photobleaching and clinical efficacy during dermatological photodynamic therapy. Journal of Photochemistry and Photobiology, v, 103, p. 17, 2011.

${ }^{35}$ PENG, Q.; BERG, K.; MOAN, J.; KONGSHAUG, M.; NESLAND, J.M. 5-

Aminolevulinic acid based photodynamic therapy: principles and experimental research, Journal Photochemistry Photobiology,v.65, p. 235-251, 1997.

${ }^{36}$ LUCROY, M. D. Photodynamic therapy for companion animals with cancer. The Veterinary Clinics of North America: Small Animal Practice, v.32, n.3, p.693- 702, 2002.

${ }^{37}$ NUNES, S. M. T.; SGUILLA, F.S.; TEDESCO, A. C. Photophysical studies of zinc phthalocyanine and chloroaluminumphthalocyanine incorporated into liposomes in the presence of additives. Brazilian Journal Medical Biology Research, v.37, n.2, p. 273-84, 2004. 
${ }^{38}$ IKRAM, M.; KHAN, R U. FIRDOUS, S.; ATIF, M.; NAWAZ, M. Photodynamic therapy of nom-melanoma skin Cancers. Laser Physics, v. 21, n. 2, p. 427- 433, 2011.

${ }^{39}$ LOPEZ, R. F. V.; LANGE, N.; GUY. R.; BENTLEY, M. V. L. B. Photodynamic therapy of skin cancer: controlled drug delivery of 5-ALA and its esters. Advanced Drug Delivery Reviews,v.56, p.77-94, 2004.

${ }^{40}$ SCHLEIER, P.; BERNDT, A.; KOLOSSA, S.; ZENK, W.; HYCKEL, P.; SHULTZEMOSGAU, S.; Comparison of aminolevulinic acid (ALA) thermo gel PDT with methyl ALA thermo gel PDT in basal cell carcinoma. Photodiagnosis and photodynamic therapy, v.4, p. 197-201, 2007.

${ }^{41}$ DOUGHERTY, T.J.; GOMER, C.J.; HENDERSON, B.W.; JORI, G.; KESSEL, D.;KORBELIK, M.; MOAN, J.; PENG, Q. Photodynamic therapy. Journal of the National Cancer Institute, v.90, n.12, p.889-905,1998.

${ }^{42}$ KORMEILI, T.; YAMAUCHI, P. S.; LOWE, N. J. Topical photodynamic therapy in clinical dermatology. British Journal of Dermatology, v. 150, p. 1061-1069, 2004.

${ }^{43}$ KRAMER-MAREK, G.; SERPA, C.; SZURKO ,A.; WIDE, M, SOCHANIK, A.; OENIETURA, M. et al. Spectroscopy properties and photodynamic effects of new lipophlicporphhyrin derivatives: efficacy, localization and cell death pathways. Journal Photochemistry Photobiology, v.84, p.1-14, 2006.

${ }^{44}$ RIBEIRO, J. N.; JORGE, R. A.; SILVA, A. R.; FLORES, A. V.; RONCHI, L. M.; TEDESCO, A. C. Avaliação da atividade fotodinâmica de porfirinas para uso em terapia fotodinâmica através da fotoxidação de triptofano. Eclética Química., vol.32, p. 7-14, 2007.

${ }^{45}$ SETUPAL, C. A. Procura por novos fotossensibilizadores para uso em terapia fotodinâmica. 2007. Dissertação de Mestrado. Setor de ciências Exatas da Universidade Federal do Paraná.

${ }^{46}$ CLARK C, BRYDEN A, DAWE RS, ET AL. Topical 5-aminolaevulinic acid photodynamic therapy for cutaneous lesions: outcome and comparison of light sources. Photodermatology, Photoimmunology, and Photomedicine, v.19, p.13441, 2003. 
${ }^{47}$ MACCORMACK, M.A. Photodynamic therapy in Dermatology: an update on applications and outcomes. Seminars in Cutaneous Medicine and Surgery, v.7, p.52-62, 2008.

${ }^{48}$ NADEAU, V; O'DWYER, M; HAMDAN, K.; TAIT, I.; PAGGETT, M. In vivo measurement of 5 -aminolaevulinic acid-induced protoporphyrin IX photobleaching: a comparison of red and blue light of various intensities. Photodermatology photoimmunology \& photomedicine, vol.20, p. 170-174, 2004.

${ }^{49}$ ASH, D.V.; BROWN, S.B.New drugs and future developments in photodynamic therapy. European Journal of Cancer,v.29, p.1781-3, 1993.

${ }^{50}$ KALKA, K.; MERK, H.; MUKHTAR, H. Photodynamic therapy in dermatology. Journal of the American Academy of Dermatology, v. 42, p.389-413, 2000.

${ }^{51}$ UEHLINGER, P.; ZELLWEGER, M.; WAGNIE`RES, G.; JUILLERAT-JEANNERET, L.; BERGH, H. V. D.; LANGE, N. 5-Aminolevulinic acid and its derivatives: physical chemical properties and protoporphyrin IX formation in cultured cells. Journal of Photochemistry and PhotobiologyB:Biology,v.54 p.72-80, 2000.

${ }^{52}$ ARAÚJO, L. M. P. DE C. Dendrímeros como carreadores de protoporfirina IX para a terapia fotodinâmica tópica do câncer de pele. 2010. Tese de Doutorado. Programa de Pós-Graduação em Ciências Farmacêuticas.

${ }^{53}$ TYRRELL, J.; CAMPBELL, S.; CURNOW, A. Protoporphyrin IX photobleaching during the light irradiation phase of standard dermatological methyl-aminolevulinate photodynamic therapy. Photodiagnosis and Photodynamic Therapy, v. 7, p. 232238, 2010.

${ }^{54}$ TYRRELL, J.; THORN, C.; SHORE, A.; CAMPBELL, S.; CURNOW, A. Oxygen saturation and perfusion changes during dermatological methylaminolaevulinate photodynamic therapy. British Association of Dermatologists, v.165, p.1323-1331, 2011.

${ }^{55}$ Zezell, D.; NICOLA, J.H. New Method for Monitoring the Efficiency of Photodynamic Therapy with HpD in Real-Time - First Results 'in vitro'. Physics in Medicine and Biology, v. 9, p. 246-250, 1993. 
${ }^{56}$ WEBBER, J.; KESSEL, D.; FROMM, D. Side-effects and photosensitization of human tissues after aminolevulinic acid, Journal of Surgical Research, v. 68 p. 3137, 1997.

${ }^{57}$ ATKINS, P.; DE PAULA, J. Físico-química. 7. Ed. Rio de Janeiro: LTC-Livros Técnicos e Científicos, v. 2, 2004.

${ }^{58}$ LAKOWICZ, J. R.; Principles of Fluorescense Spectroscopy, 2nd ed., Plenum Press: New York, 1998.

${ }^{59}$ SAAGER, R. B.; CUCCIA, D. J.; SAGGESE, S.; KELLY, K. M.; DURKINA, A. J. Quantitative fluorescence imaging of protoporphyrin IX through determination of tissue optical properties in the spatial frequency domain. Journal of Biomedical Optics,v.16, p.1260131-5, 2011.

${ }^{60}$ SINAASAPPEL, M.; STERENBORG, H.J.C.M. Quantification of the hematoporphyrin derivative by fluorescence measurement using dual-wavelength excitation and dual wavelength detection. Applied Optics, v. 32, p.541-548, 1993.

${ }^{61}$ KASCAKOVA, S.; VISSCHER, S. D.; KRUIJT B.; BRUIJN, H. S. D.; HEUVEL, A. V. D. P.V. D.; STERENBORG, H. J. C. M.; WITJES, M. J. H.; AMELINK, A.; ROBINSON,D. J. In vivo quantification of photosensitizer fluorescence in the skin-fold observation chamber using dual-wavelength excitation and NIR imaging. Lasers in Medical Science, v.26, p.789-801, 2011.

${ }^{62}$ AMELINK, A.; KASPERS, O.P.; STERENBORG, H.J.C.N.; VAN DER WAL, J.E.; ROODENBURG, J.L.N.; WITJES, M.J.H. Non-invasive measurement of the morphology and physiology of oral mucosa by use of optical spectroscopy. Oral Oncology, v. 44, p.65-71, 2008.

${ }^{63}$ RICHARDS-KORTUM, R.; SEVICK-MURACA, E. Quantitative optical spectroscopy for tissue diagnosis. Annual Review of Physical Chemistry, v. 47, p.555-606, 1996.

${ }^{64}$ MARCU, L.; Fluorescence Lifetime Techniques in Medical Applications. Annals of Biomedical Engineering, v. 40, p.304-331, 2012. 
${ }^{65}$ NICOLAI, B. M.; BEULLENS, K.; BOBELYN, E.; PEIRS, A.; SAEYS, W.; THERON, K. I.; LAMMERTYN, J. Nondestructive measurement of fruit and vegetable quality by means of NIR spectroscopy: A review. Postharvest Biologyand Technology, v.46, n.2, p. 99-118, 2007.

${ }^{66}$ REZENDE, S. M. A Física de materiais e dispositivos eletrônicos. Recife: Educação Universitária UFPE, 1996.

${ }^{67}$ LINS, E. C. C. C. Espectroscopia de fluorescência na citricultura. 2009. Tese (Doutorado). São Carlos: Universidade São Paulo.

${ }^{68}$ CHARAMISINAU, I.; KEYMEL, K.; POTTER, W.; OSEROFF, A.R. Handheld dual fluorescence and reflectance spectroscopy system for monitoring topical low dose ALA-PDT of actinic keratoses (AK). Proc. of SPIE, v. 6139, 61391E, 2006.

${ }^{69}$ VALENTINE, R. M.; IBBOTSON, S. H.; BROWN, T. A.; WOOD, K.; MOSELEY, H. A quantitative Comparison of 5-aminolevulinic acid-and methyl aminolevulinate induced fluorescence, photobleaching and pain during photodynamic therapy. Photochemistry and Photobiology, v. 87, p.242-249, 2011.

${ }^{70}$ ANGELL-PETERSEN, E.; SORENSEN, R.; WARLOE, T.; SOLER, A.M.; MOAN, J.; PENG, Q. Porphyrin formation in actinic keratosis and basal cell carcinoma after topical application of methyl 5- aminolevulinate. Journal of Investigative Dermatology, v.126, p.265-71, 2006.

${ }^{71}$ MARSCHALL, SANDER, S.; B.; MOGENSEN, M.; JORGENSEN, T.M.; ANDERSEN, P.E. Optical coherence tomography current technology and applications in clinical and biomedical research. Analytical and Bioanalytical Chemistry, v. 400, n. 9, p.2699-2720, 2011.

72 HUANG, D.; SWANSON, E.A.; LIN C.P.; SCHUMAN, J.S.; STINSON, W.G.; CHANG, W.; HEE, M.R.; FLOTTE, T.; GREGORY, K.; PULIAFITO, C.A.; FUJIMOTO, J.G. Optical coherence tomography. Science, v.254, p.1178-1181, 1991.

${ }^{73}$ SMOLKA, G. Optical coherence tomography 2010: technology, applications, and markets (Market Report OM- 51). Strategies Unlimited (Penn Well Corporation), Mountain View, 2010. 
${ }^{74}$ SAND, M.; GAMBICHLER, T.; MOUSSA, G.; BECHARA, F. G.; SAND, D.; ALTMEYER, P.; HOFFMANN, K. Evaluation of the epidermal refractive index measured by optical coherence tomography. Skin Research and Technology, v.12, p.114-118, 2005.

${ }^{75}$ VASQUEZ, P. L.; FREITAS, A.Z.; VLEIRA, N.; GESZTESI, J.; LEO, C. Skin histomorphological correlation with optical coherence tomography $(O C T)$. Journal of investigative dermatology, v.128, p.S91-S91, 2008.

${ }^{76}$ BECHARA, F.G.; GAMBICHLER, T.; STU CKER, M. Histomorphologic correlation with routine histology and optical coherence tomography. Skin Research and Technology, v.10, p.169-173, 2004.

${ }^{77}$ FREITAS, A. Z. Caracterização de Tecidos Biológicos através de Tomografia por Coerência Óptica. 2007. Tese Doutorado. Instituto de Pesquisas Energéticas e Nucleares, São Paulo.

${ }^{78}$ KURANOV, R.V.; SAPOZHNIKOVA, V.V.; SHAKHOVA, N.M.; GELIKONOV, V.M.; ZAGAINOVA, E.V.; PETROVA, S.A. Combined application of optical methods to increase the information content of optical coherent tomography in diagnostics of neoplastic processes. Quantum Electronics, v.32, p.993-998, 2002.

${ }^{79}$ BOUMA, E. B.; TEARNEY, G. J. Handbook of optical coherence tomography. New York, N.Y: Marcel Dekker, 2002.

${ }^{80}$ FERCHER, A.F.; DREXTER, W.; HITZENBERGER, C.K.; LASSER, T. Optical coherence tomography - principles and applications. Report on Progress in Physics, v. 66, p.239-303, 2003.

${ }^{81}$ RAELE, M.P. Desenvolvimento de um sistema de tomografia por coerência óptica no domínio de Fourier sensível á polarização e sua utilização na determinação das matrizes de Mueller. 2009. Dissertação Mestrado - Instituto de Pesquisas Energéticas e Nucleares, São Paulo.

${ }^{82}$ ABEL, E.; KIGUCHI, J.; DIGIOVANNI, J. Multi-stage chemical carcinogenesis in mouse skin. Nature protocols, vol.4, n. 9, p.1351-1362, 2009. 
${ }^{83}$ RODRIGUES, C. E. Comparação da eficácia do ácido 5-aminolevulínico com a de seu metil éster utilizando-se a terapia fotodinâmica no tratamento de carcinoma espinocelular felino. 2008. Tese Doutorado - Instituto de Pesquisas Energéticas e Nucleares, São Paulo.

${ }^{84}$ DONELLY, R.F., JUZENAS, P., CARRON, M.C.; MAL, P.A.; WOOLFSON, A.D., MOAN, J. Influence of fomulation factors on methyl-ALA-induced protoporphyrin IX accumulation in vivo. Photodiagnosis and Photodynamic Therapy, n.3, p.190-201, 2006.

${ }^{85}$ SAKAMOTO, F. H.; IZIKISON, L.; TANNOUS, D.; ZURAKOWSKI. D.; ROX, A. R. Surgical scar remodelling after photodynamic therapy using aminolaevulinic acid or its methylester: a retrospective, blinded study of patients with field cancerization.

Association of Dermatologists, v.166, n. p413-416, 2012.

${ }^{86}$ SZEIMIES, R. M.; MORTON, C.A; SIDOROFF, A.; BRAATHEN, L. R. Photodynamic therapy for non-melanoma skin cancers. Acta Derm Venereol, v. 85, p.483-490, 2005.

${ }^{87}$ FREITAS, A. Z.; Amaral, M. M.; Raele, M. P. Optical Coherence Tomography:

Development and Applications. In: F. J. Duarte. Laser Pulse Phenomena and Applications. 1ed. Austria: InTech Education and Publishing, p. 409-432, 2010.

${ }^{88}$ LESAR, A.; FERGUSON, J.; MOSELEY, H. A time course investigation of the fluorescense induced by topical application of 5-aminolevulinic and methyl aminolevulinate on normal human skin. Photodermatology, Photoimmunology, and Photomedicine, v. 25, p.191-195, 2009.

${ }^{89}$ VALENTINE, R. M.; IBBOTSON, S. H.; BROWN, C. T.;WOOD, K.; MOSELEY, H. A quantitative comparison of 5-aminolaevulinic acid and methyl aminolevulinate induced fluorescence, photobleaching and pain during photodynamic therapy. Photochemistry and Photobiology, v. 87, p.242-249, 2011.

${ }^{90}$ LESAR, A.; FERGUSON, J.; MOSELEY, H. An investigation of the fluorescence induced by topical application of 5-aminolevulinic and methyl aminolevulinate at 
different body sites on normal human skin. Photodiagnosis and Photodynamic Therapy, v. 8, p.97-103, 2011.

${ }^{91}$ PENG, Q.; SOLER, A. M.; WARLOE, T.; NESLAND, J. M.; GIERCKSK, K. E. Selective distribution of porphyrins in skin thick basal cell carcinoma after topical application of methyl 5-aminolevulinate. Journal of Photochemistry and Photobiology Biology, vol. 62, p.140-145, 2001.

92 JUZENAS, P.; SHARFAEI, S., MOAN, J.; BISSONNETTE, R. Protoporphyrin IX fluorescence kinetics in UV-induced tumours and normal skin of hairless mice after topical application of 5-aminolevulinic acid methyl ester. Journal of Photochemistry and Photobiology Biology, vol. 67, p.11-17, 2002.

${ }^{93}$ FRITSCH, C.; HOMEY, B.; STAHL, W.; LEHMANN, P.; RUZICKA, T.; SIES, H. Preferential relative porphyrin enrichment in solar keratoses upon topical application of delta-aminolevulinic acid methylester. Photochemistry and Photobiology, vol.68, p.218-221, 1998.

${ }^{94}$ PANJEHPOUR, M.; JULIUS, C. E.; PHAN, M. N.; VO-DINH, T.; OVERHOLT, S. Laser-Induced Fluorescence Spectroscopy for In Vivo Diagnosis of Non-melanoma Skin Cancers. Lasers in Surgery and Medicine, v. 31, p.367-373, 2002.

${ }^{95}$ MOGENSEN, M.; JEMEC,G. B. E. Diagnosis of Nonmelanoma Skin Cancer/Keratinocyte Carcinoma: A Review of Diagnostic Accuracy of Nonmelanoma Skin Cancer Diagnostic Tests and Technologies. Dermatology Surgery, v.33, p.1158-1174, 2007.

${ }^{96}$ KHOLODNYKH, A. I.; PETROVA, I. Y.; MOTAMEDI, M.; ESENALIEV, R.O. Accurate Measurement of Total Attenuation Coefficient of Thin Tissue With Optical Coherence Tomography. Journal on selected topics in quantum electronics, v.9, p. 210-221, 2003.

${ }^{97}$ THRANE, L.; YURA, H.T.; ANDERSEN, P. E. Analysis of optical coherence tomography systems based on the extended HuygensFresnel principle. Journal of the Optical Society of America, v.17, p.484-490, 2000.

${ }^{98}$ FABER, D.J.; VAN DER MEER, F.J.; AALDERS, M.C.G. Quantitative measurement of attenuation coefficients of weakly scattering media using optical coherence tomography. Optics express, v.12, p. 4353-4365, 2004. 
${ }^{99}$ KORDE, V. R.; BONNEMA, G. T.; XU, W.; KRISHNAMURTHY, C.; RANGER, M, J.; SABODA, K.; SLAYTON, L.D.; SALASCHE, S. J.; WARNEKE, J. A.; ALBERTS, D.S.; BARTON, J. K. Using optical coherence tomography to evaluate skin sun damage and precancer. Lasers in Surgery and Medicine, v. 39, p.687-695, 2007. 